August 2000

IMF Staff Country Report No. 00/103

\title{
Burkina Faso: Recent Economic Developments
}

This Recent Economic Developments report on Burkina Faso was prepared by a staff team of the International Monetary Fund as background documentation for the periodic consultation with this member country. As such, the views expressed in this document are those of the staff team and do not necessarily reflect the views of the Government of Burkina Faso or the Executive Board of the IMF.

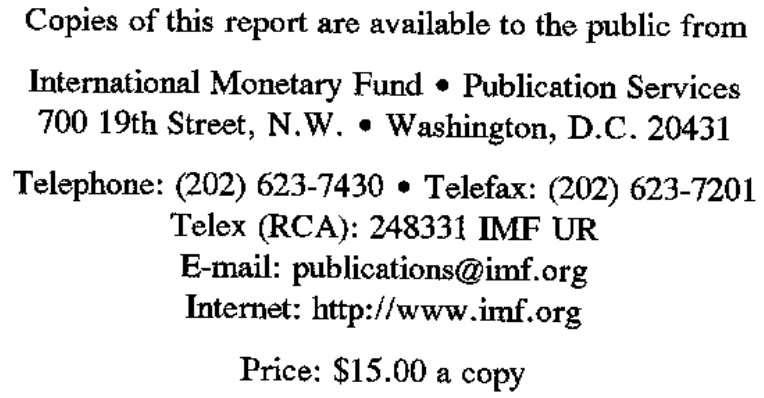

\section{International Monetary Fund Washington, D.C.}




\section{INTERNATIONAL MONETARY FUND}

\section{BURKINA FASO}

\section{Recent Economic Developments}

Prepared by a staff team consisting of Mr. E. Sacerdoti (head), Mr. P. Lazar, Ms. L. Allain (EP), Ms. S. Brunschwig, and Mr. N. Krichene (all AFR)

Approved by the African Department

June 13, 2000

Contents

Basic Data .4

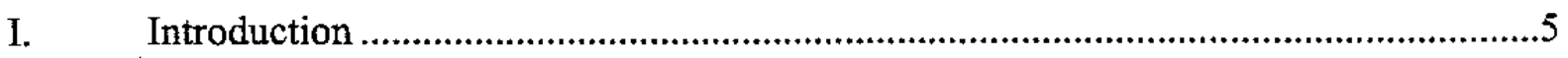

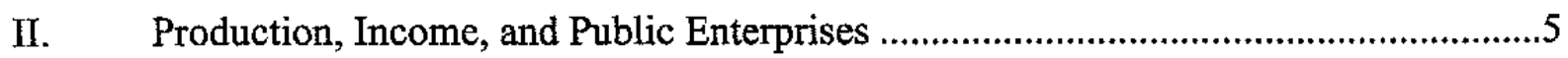

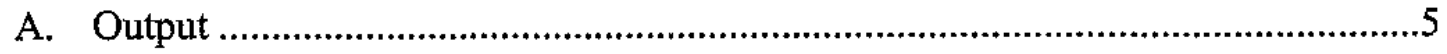

B. Domestic Demand...........................................................................................

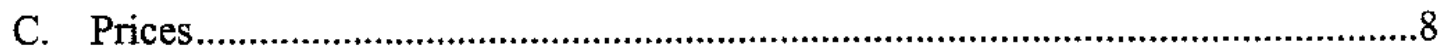

D. Public Enterprise Restructuring ..........................................................................

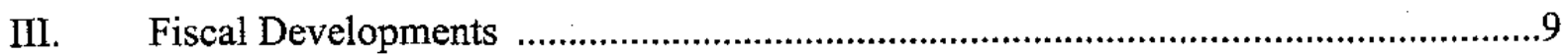

A. Overall Developments ....................................................................................

B. Government Revenue and Tax Administration Reform....................................12

C. Developments in Expenditure............................................................................14

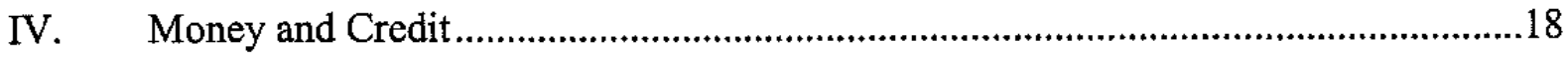

A. Monetary Developments.................................................................................19

B. Monetary Policy..............................................................................................19

C. Development of Credit Activity ......................................................................2

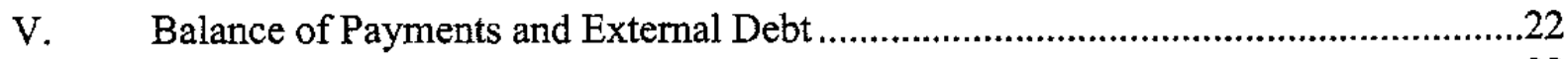

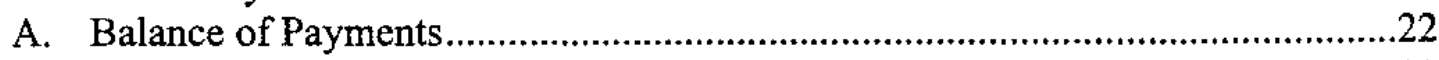

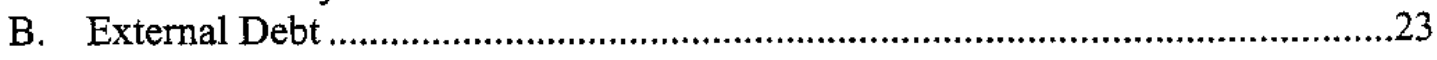

Text Boxes

1. Privatization and Liquidation of Public Enterprises ..................................................10

2. Reform of External Tariff Structure, 1998-2000 .....................................................12 


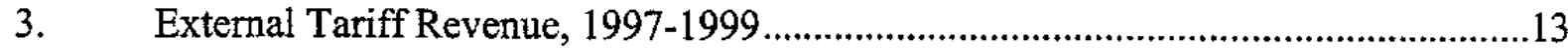

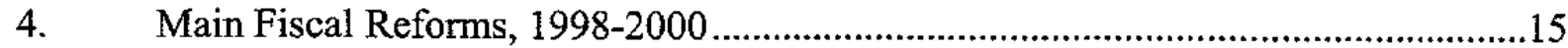

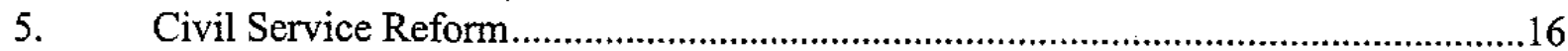

6. Expenditure on Health and Education..................................................................17

Figures

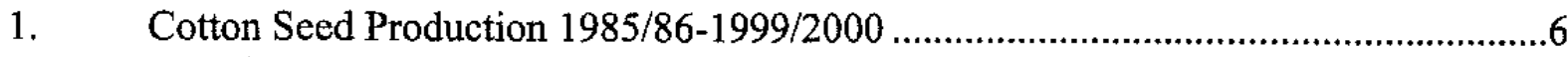

2. Distribution of Foreign-Financed Public Investment, 1996-99 ...............................18

Appendixes

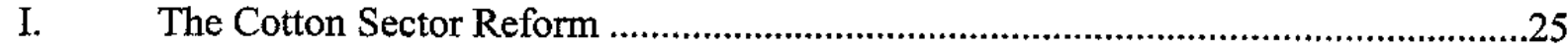

II. Developments of Decentralized Financial Systems (DFSs) .....................................30

III. Summary of the Tax System, January 1, 2000 ........................................................33

IV. Statistical Appendix Tables

1. Gross Domestic Product by Sector at Constant 1985 Prices, 1995-1999 …...............40

2. . Gross Domestic Product by Sector at Current Prices, 1995-1999 …..........................41

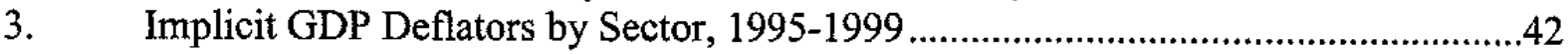

4. Supply and Use of Resources in Current Prices, 1995-1999 ....................................43

5. Production of Principal Crops, 1995/96-1999/00 .....................................................44

6. Producer Prices for Principal Crops, 1992/93-1999/2000 ……................................45

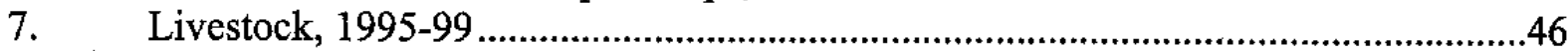

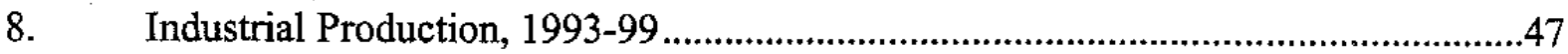

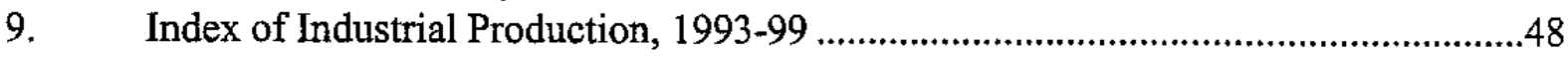

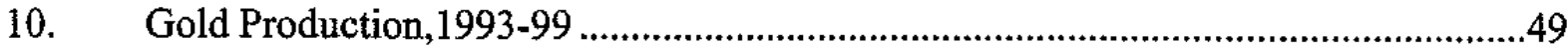

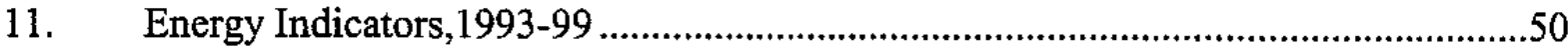

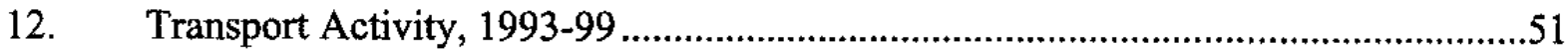

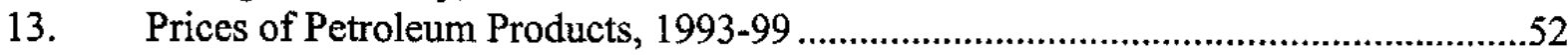

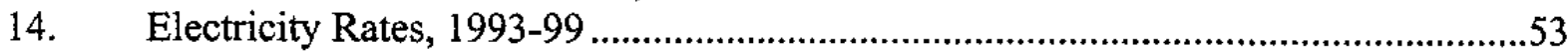

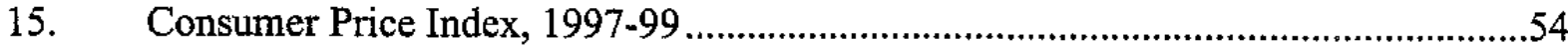

16. Consolidated Operations of the Central Government, 1993-99 ...............................55

17. Economic Classification of Consolidated Government Expenditure, 1993-99 .........56

18. Public Investment Program, 1993-99 ....................................................................57

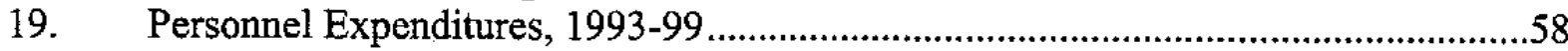

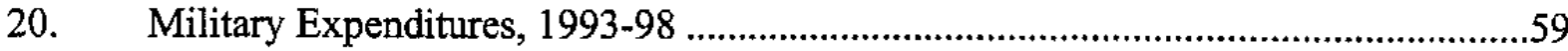

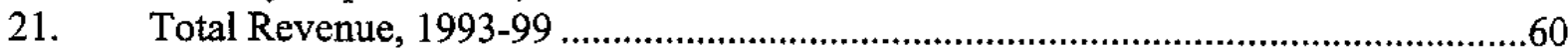

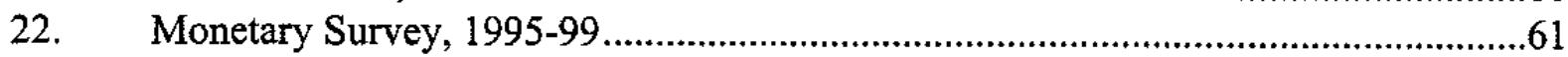

23. Summary Accounts of the Central Bank, 1995-99 …............................................62

24. Summary Accounts of Deposit Money Banks, 1995-99 ............................................63

25. Central Bank Interest Rates, January 1996-December 1999...................................64

26. Money Market Interest Rates, January 1996-December 1999 ..................................65 
27. Maximum Lending Rates Applied by Commercial Banks, October 1993-December 1999.

28. Deposit Rates Applied by Commercial Banks, November 1989-December 1999 ....67

29. Balance of Payments, 1993-99 (in billions of CFA francs) ......................................68

30. Balance of Payments, 1993-99 (in millions of SDRs) .........................................69

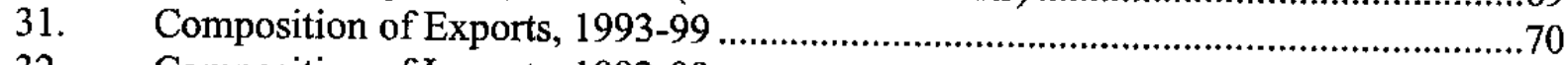

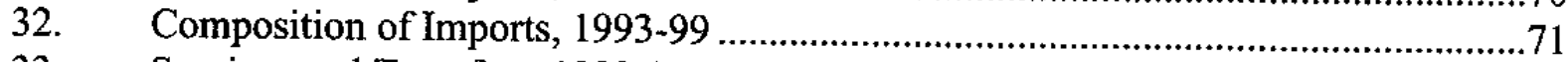

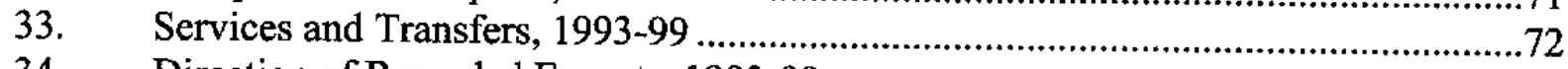

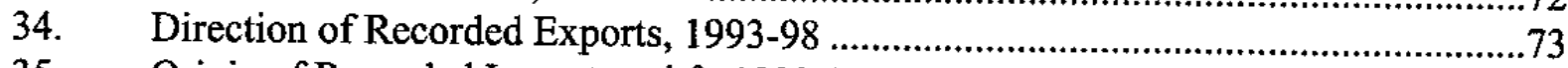

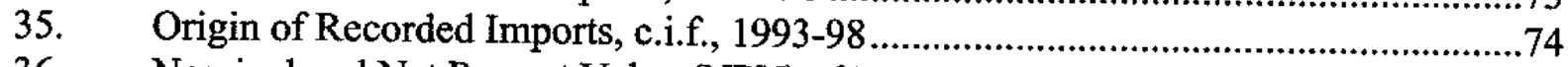

36. Nominal and Net Present Value (NPV) of External Debt Outstanding, as of End-

December 1999 
Burkina Faso: Basic Data, 1995-99

\begin{tabular}{|c|c|c|c|c|c|c|}
\hline \multirow{2}{*}{\multicolumn{7}{|c|}{ Area, population, and GDP per capita }} \\
\hline Area: & & & & & & \\
\hline Population; Total (1999) & 11.1 million & & & & & \\
\hline Growth rate & 2.4 percent & & & & & \\
\hline GDP per capita & US\$230 & & & & & \\
\hline & & 1995 & 1996 & 1997 & 1998 & 1999 \\
\hline & & & (ln billio & ne of CFA f & ance) & \\
\hline Gross Domestic Product & & & & & & \\
\hline Total & & $1,175.5$ & $1,298.3$ & $1,390.1$ & $1,522.4$ & $1,588.6$ \\
\hline At constant 1985 prices & & 857.2 & 908.4 & 951.6 & $1,010.2$ & $1,068.8$ \\
\hline Per capita real incoure & & 79.6 & 82.3 & 84.3 & 87.0 & 89.5 \\
\hline & & & (In pe & rcent of GD & & \\
\hline Primary sector & & 40.2 & 40.6 & 383 & 38.1 & 37.0 \\
\hline Secondary sector & & 18.6 & 18.0 & 19.1 & 20.0 & 20.8 \\
\hline Tertiary sector & & 41.3 & 41.4 & 42.7 & 42.0 & 42.1 \\
\hline & & & (Arunual $\mathrm{p}$ & ercentage ch & anges) & \\
\hline Nominal GDP & & 14.2 & 10.4 & 7.1 & 9.5 & 4.4 \\
\hline Real ODP & & 4.0 & 6.0 & 4.8 & 6.2 & 5.8 \\
\hline Prices & & & & & & \\
\hline GDP deflator & & 9.8 & 4.2 & 2.2 & 3.2 & -1.4 \\
\hline Consumer price index & & 7.8 & 6.1 & 2.3 & 5.0 & -1.1 \\
\hline & & & (n billion & 1s of CFA fi & uncs) & \\
\hline Central government finance & & & & & & \\
\hline Reverue and zrants & & 224.6 & 269.1 & 279.3 & 303.0 & 379.2 \\
\hline Total expenditure and net lending & & 245.8 & 276.8 & 323.3 & 347.9 & 433.7 \\
\hline Of which: current experditure & & 132.0 & 134.8 & 140.5 & 158.0 & 179.3 \\
\hline capital expenciture & & 116.7 & $\$ 43.7$ & 185.3 & 190.4 & 254.1 \\
\hline Ovenal deficit (commitment basis) & & -21.1 & -7.7 & -44.0 & -44.9 & -54.5 \\
\hline Change in arreas & & -19.9 & +17.2 & -6.5 & -5.5 & -9.1 \\
\hline Overal deficit (cash basis) & & -41.3 & -24.9 & -50.5 & -50.3 & -63.8 \\
\hline Finarcing & & 41.1 & 24.9 & 50.5 & 50.3 & 63.8 \\
\hline Forrigl & & 55.6 & 32.8 & 31.0 & 52.4 & 62.0 \\
\hline Domentic & &. .14 .6 & -7.9 & 19.5 & -2.1 & 1.8 \\
\hline Money and credit & & & & & & \\
\hline Net foreign assets & & 234.1 & 226.2 & 203.1 & I85.0 & 177.9 \\
\hline Net domeatic assets & & 82.0 & 107.5 & 153.0 & 204.3 & 238.4 \\
\hline Of which: net claims to Gov't & & -5.3 & 6.2 & 37.1 & 37.1 & 50.2 \\
\hline credit to the ecorlony & & 82.4 & 115.2 & 135.4 & 180.2 & 188.0 \\
\hline Money and quasi money & & 299.7 & 324.4 & 367.2 & 376.9 & 401.4 \\
\hline Balance of payments & & & & & & \\
\hline Exports, f.o.b. & & 118.2 & 119.0 & 133.7 & 190.4 & 156.6 \\
\hline Imports, f.o.b. & & -242.2 & -288.0 & -297.7 & -374.2 & -368.7 \\
\hline Trade balance & & -124.1 & -168.9 & -164.0 & -183.8 & -212.0 \\
\hline Services (net) & & -61.6 & -64.7 & -72.9 & -80.5 & -83.3 \\
\hline Transfers & & 166.2 & 192.4 & 187.2 & 200.9 & 217.8 \\
\hline Current account & & -66.4 & -128.7 & -141.4 & -152.8 & .200 .3 \\
\hline Excluding current transfers & & -132.8 & -190.6 & -193.6 & -220.4 & -254.3 \\
\hline Capital infiows (net) & & 55.2 & 41.4 & 28.5 & 38.3 & 64.7 \\
\hline Errors and amisions & & 32.5 & -2.0 & -1.7 & 2.6 & -0.7 \\
\hline Overall balance & & 68.2 & -1.8 & -23.0 & -22.4 & -13.5 \\
\hline Financing & & -68.2 & 1.8 & 23.0 & 22.4 & 13.5 \\
\hline Change in net foreign argets & & -71.4 & 0.7 & 20.2 & 19.6 & 9.4 \\
\hline Change in arrears & & -1.4 & 0.0 & 0.0 & 0.0 & 0.0 \\
\hline Debt relief & & 4.6 & 1.3 & 2.8 & 2.8 & 4.2 \\
\hline Gross official reserves & & & & & & \\
\hline Grobs official reperves & & 295.1 & 296.5 & 306.7 & 307.3 & 300.8 \\
\hline In months of imports, cif. & & 12.5 & 10.7 & 10.6 & 8.3 & 8.3 \\
\hline External public debt & & & & & & \\
\hline Disburted and outstanding & & 666.3 & 702.8 & 744.8 & 800.9 & 843.8 \\
\hline Debt kervice ratio $1 /$ & & 22.9 & 21.7 & 24.2 & 16.6 & 23.3 \\
\hline Arrears & & 6.7 & 0.0 & 0.0 & 0.0 & 0.0 \\
\hline & & & (CFA fran & s per U.S. d & olliar) & \\
\hline Exchange rate & & & & & & \\
\hline End of period & & 490.0 & 523.7 & 598.8 & 562.2 & 653.0 \\
\hline Period avernge & & 499.2 & 512.0 & 583.7 & 590.0 & 6157 \\
\hline
\end{tabular}

Sources: Burkinabé authorities, and staff ertimates.

$1 /$ In percent of exporte of goods and nonfactor services. 


\section{INTRODUCTION}

1. Burkina Faso is a landlocked country in the Sahel region of West Africa. With a GDP per capita estimated at US\$230 in 1999, it is one of the poorest countries in the world. The resident population was about 11.1 million in 1999 , and 84 percent live in rural areas. Burkina Faso has few natural resources and limited rainfall. Climatic conditions are particularly difficult in the north, where frequent droughts and environmental degradation caused by current farming practices result periodically in severe food shortages.

2. During most of the 1980 s, Burkina Faso followed a development strategy based on central planning and pervasive controls that resulted in large macroeconomic imbalances. In 1991, Burkina Faso adopted a structural adjustment program aimed at restoring growth and reducing fiscal deficits. In 1994, in order to regain international competitiveness, the CFA franc was devalued against the French franc from $F 1=$ CFAF 50 to $F 1=C F A F 100$. This devaluation, combined with fiscal adjustment and structural reforms, has revived economic growth and reversed the decline in GDP per capita. Nevertheless, social indicators remain extremely low and poverty continues to affect large sections of the population. Reducing poverty has become the focus of the government's economic development strategy.

\section{Production, Income, ANd Public EnTerprises}

\section{A. Output}

3. Real GDP increased in 1999 by 5.8 percent after a 6.2 percent growth in 1998 (Table 1), thus sustaining the upward trend observed since 1995 . The favorable growth performance during the 1995-99 period (5.3 percent in real terms) is in sharp contrast with the sluggish growth and declining per capita incomes that prevailed in the predevaluation period.

4. The key factors in building the growth momentum were the devaluation in 1994, the high investment ratio, averaging about 27 percent of GDP in 1995-99 (Table 4), and the sound macroeconomic policies and structural reforms under successive adjustment programs, which improved the environment for private sector activities. Recent studies indicate that policies in Burkina Faso would need to continue to focus on the liberalization of the economy, the improvement of external competitiveness, and the development of the economic and social infrastructure. ${ }^{1}$

5. The primary sector, which contributes about 30 percent of GDP at current prices (Table 2), grew by 3.1 per-cent in 1999 in real terms (5.5 percent in 1998). Following a record increase of 17 percent in crop year 1998/99, the cereals output increased further by

\footnotetext{
${ }^{1}$ See World Bank, Burkina Faso: Competitiveness and Economic Growth, May 1999.
} 
1.6 percent in 1999 to 2.7 million tons (Table 5). ${ }^{2}$ Seed cotton production is estimated at 280,000 tons in $1999 / 2000$ compared with 284,500 tons in 1998/99 and an average of 300,000 tons over the last three crop years (Figure 1). Thus, the strong gains in cotton production achieved since 1995 have been preserved, as in 1999/2000 some decrease in the cultivated area has been offset by an increase in productivity. This expansion was due to a combination of factors, including the 1994 devaluation and the structural reforms in the sector; it has helped raise farmers' income and improved the profitability in the cotton sector (see Appendix I). Stimulated by a sharp rise in prices, output of oilseed leaped by about 31 percent to an output level of 339,000 tons in 1999 . Livestock, numbering about 20 million heads of cattle, and forestry and fishing continued to grow, as in previous years, at a broadly stable rate.

Figure 1. Burkina Faso: Cotton Seed Production, 1985/86-1999/2000

(In thousands of metric tons)

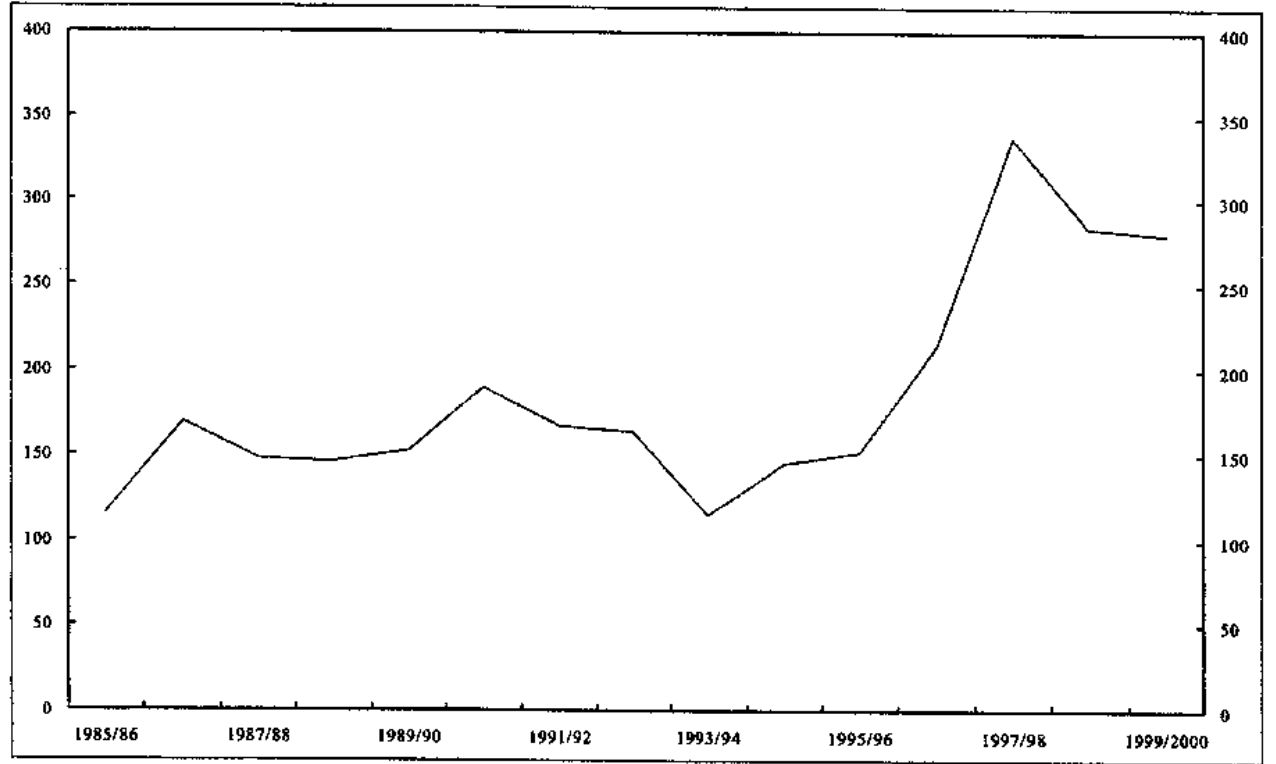

6. Despite the steady increase in production, the development of the primary sector continues to be constrained by the lack of infrastructure and adequate capital, and-in the case of subsistence crops-by the lack of adequate marketing channels. Thus the rice sector, while offering significant potential for increased output, is handicapped by the lack of ginning capacity and marketing outlets. There is scope to increase production substantially in

${ }^{2}$ This figure represents gross output. Net output was estimated at 2.3 million tons. The cereals deficit was estimated at about 162,000 tons, most of it (110,000 tons) covered by imports. 
cotton and cereals, provided farmers acquire essential tools and have access to financing. There is also scope to expand significantly production and exports of fruits and vegetables, including mangos, sesame, and karite. Such an expansion would have the benefit of diversifying production and making the economy less vulnerable to external shocks.

7. The secondary sector, representing about 21 percent of GDP, maintained in 1999 the strong growth trend observed in the last three years of about 10.7 percent a year on average. While the production of cotton fiber has jumped upward in line with that of seed cotton, almost all other industries have seen their output expand. In particular, there has been an expansion in cement, brewery, and motorcycle assembly, reflecting in part the gain in competitiveness after the 1994 devaluation and the steady domestic demand growth. Owing to the high investment rate in the economy and, more particularly, important projects in the public investment program, such as the Ziga dam and the road construction projects, the construction and public works sector experienced sustained growth (7.3 percent in real terms on average in 1997-99) and contributed significantly to overall growth in the secondary sector.

8. The energy sector (electricity, gas, and water), accounting for about 4 percent of the secondary sector, experienced fast growth (6 percent in real terms on average in 1997-99), thanks in part to important investment in the form of new dams, water adduction, and additional power generation capacity. Electricity production, which increased at a rate of about 11 percent a year in 1995-99, stood at 320 million kilowatt-hours in 1999. The high electricity prices in Burkina Faso weaken competitiveness and are being addressed through a number of projects that are in preparation; these include the interconnection with the Cote d'Ivoire power grid, the construction of the transportation line Bobo DioulossoOuagadougou, and the expansion and modernization of generation capacity. In 1999, petroleum prices were adjusted upward, reflecting higher import prices; thus, the price of gasoline rose from CFAF 397 per liter at end-1998 to CFAF 410 per liter at end-1999 (Table 13).

9. In the mining sector, delays in completing the rehabilitation of the country's largest gold mining site, Poura, which used to produce some 3 tons of gold per year, explain most of the decline in gold production since 1993 (Table 10). In 1999, gold production, which is at present conducted essentially on a nonindustrial basis, continued to fall, mainly because of the sharp drop in gold export prices. Traditional gold panning is prevalent at over 200 sites throughout the country and provides a livelihood for some 75,000 miners. Production also includes some industrial production from two small companies in which the government has a minority share. In recent years, intense exploration activity by a number of international firms has led to important findings (see chapter 5, page 22). The government has put in place, since 1998, a four-point program for strengthening the mining sector (PRECAGEME): (i) a regulatory, fiscal, and training framework; (ii) institutional strengthening, including the establishment of a land permit registry; (iii) environmental protection; and (iv) support to the small-scale and traditional mining activities. 
10. The tertiary sector, representing about 38 percent of GDP, maintained a strong upward trend in the period 1995-99, growing on average at a rate of 6.3 percent a year in real terms. This growth reflected the buoyancy of the primary and secondary sectors, and the expansion of investment. The expansion of the transport sector was facilitated by the liberalization of that sector and the investment in road infrastructure. In telecommunications, the telecommunications company (ONATEL) continued its expansion plan by adding new lines and developing its satellite connections. Government services increased on average by 3.7 percent in 1995-99; with the adoption of the new salary grid in 1999, the government wage bill rose in nominal terms by 10 percent during the year. In keeping with its social policies, the government has steadily increased recruitment in the education and health sectors, helping to raise the overall size of the civil service from 45,680 in 1996 to 50,422 in 1999.

\section{B. Domestic Demand}

11. Total investment rose from 23.9 percent of GDP in 1995 to 27.8 percent of GDP in 1999, averaging about 27.1 percent of GDP during that period (Table 4). This is the result of a strong increase in public investment, from 10.2 percent of GDP in 1995 to 15.9 percent in 1999 , and also the recovery in private investment, which rose from 13.6 percent of GDP in 1995 to 16.0 percent in 1998 before falling to 11.9 percent in 1999 . The strong increase in private investment in 1998 reflected construction activity related to the hosting of both the Summit of the Organization of African Unity and the African Nations Soccer Cup; it reflected also expansion of production facilities in brewery and cement. During this period, domestic savings rose sharply from 8.6 percent of GDP in 1995 to 12.7 percent of GDP in 1998 , before subsiding to 9.8 percent in 1999 ; the overall improvement was mainly on account of a substantial increase in private savings which rose from 3.9 percent of GDP in 1995 to 5.6 percent in 1999. Public savings rose from 4.7 percent of GDP in 1995 to 7.2 percent in 1998 . The sharp increase in domestic savings stemmed from a number of factors, including (i) the sustained growth of GDP in 1995-99; (ii) positive domestic real interest rates; (iii) the 1994 devaluation, which helped reduce domestic absorption, narrow the budget deficit, and increase the profitability of the tradable goods sector; (iv) the improvement in the terms of trade; and (v) the ensuing recovery in exports. The savingsinvestment gap increased slightly from 15.3 percent of GDP in 1995 to 18.1 percent in 1999 , and continued to be covered by external grants and highly concessional loans.

\section{Prices}

12. The consumer price index (CPI) fell by 1.1 percent in 1999 (Table 15), reflecting the favorable impact of a good supply of food crops. Following the devaluation-induced jump of 24.7 percent in 1994, the CPI inflation showed strong declining trends thereafter. The CPI in Burkina Faso is influenced not only by the supply of domestically-produced foodstuff, mainly cereals, but also by the fixed exchange rate regime, including the movements of the exchange rate of the CFA franc vis-à-vis the U.S. dollar. 
13. The GDP deflator fell by 1.4 percent in 1999 (Table 3), owing to the sharp fall in cotton export prices and the decline in cereal prices. In the aftermath of the 1994 devaluation, the growth of the GDP deflator displayed a declining trend, reflecting the stable wages, stable international prices, and restrained domestic demand policies.

\section{Public Enterprise Restructuring}

14. The public enterprise restructuring program which began in 1991 covers 44 enterprises (Box 1). As of end-1999, 22 enterprises had been privatized, generating privatization proceeds estimated at CFAF 11.2 billion; 3 enterprises had been withdrawn from the program; and 11 enterprises had been liquidated; meanwhile, 8 enterprises-including the air carrier (Air Burkina) and the telephone company (ONATEL)-are being privatized.

15. In the telecommunications sector, the government adopted in 1999 the regulatory and legislative framework for private sector participation in this sector. Two licenses for mobile communications were awarded in March 2000. The recruitment of an investment bank that will be responsible for seeking private investors is slated for May 2000 , and the privatization of ONATEL is expected to be completed by end-2000 or early 2001 . Following the opening up of electricity production to the private sector in 1999, a new regulatory framework for the electricity sector will be prepared during 2000 , and the specific scheme for the privatization of the electricity company (SONABEL) will be finalized by end- 2000 .

16. With a view to enhancing the environment for the private sector, the investment procedures were streamlined through the establishment of a "one-stop shop," the chambers of commerce and industry were restructured, the "House of the Entrepreneur" was established, and the business laws were modernized in the context of the Organization for the Harmonization of Business Laws in Africa (OHADA). The nonbank financial sector, including the postal checking, and the national savings institution, are being restructured, and a major emphasis is being given to the development of microfinance.

\section{Fiscal Developments}

\section{A. Overall Developments}

17. Significant progress was made in improving public finances over the past two years in the context of Fund-supported adjustment programs. The common external tariff (CET) of the Western Africa Economic and Monetary Union (WAEMU) was introduced in stages between July 1, 1998 and January 1, 2000, while important reforms of the tax and customs administrations were implemented to broaden the tax base and reinforce tax collection. As a result, despite the revenue losses caused by the introduction of the CET (see below), government revenue rose from 12.3 percent of GDP in 1996 to 13.5 percent of GDP in 1999 (15 percent, including duties paid by the treasury on imports for foreign financed public investment projects)(Table 21). On the expenditure side, a major civil service reform was introduced on January 1, 1999 that included a new, wider wage scale and a merit-based promotion system; at the same time, the allocations for health and education were increased, and the public investment program was implemented at a steady pace. These measures led to 


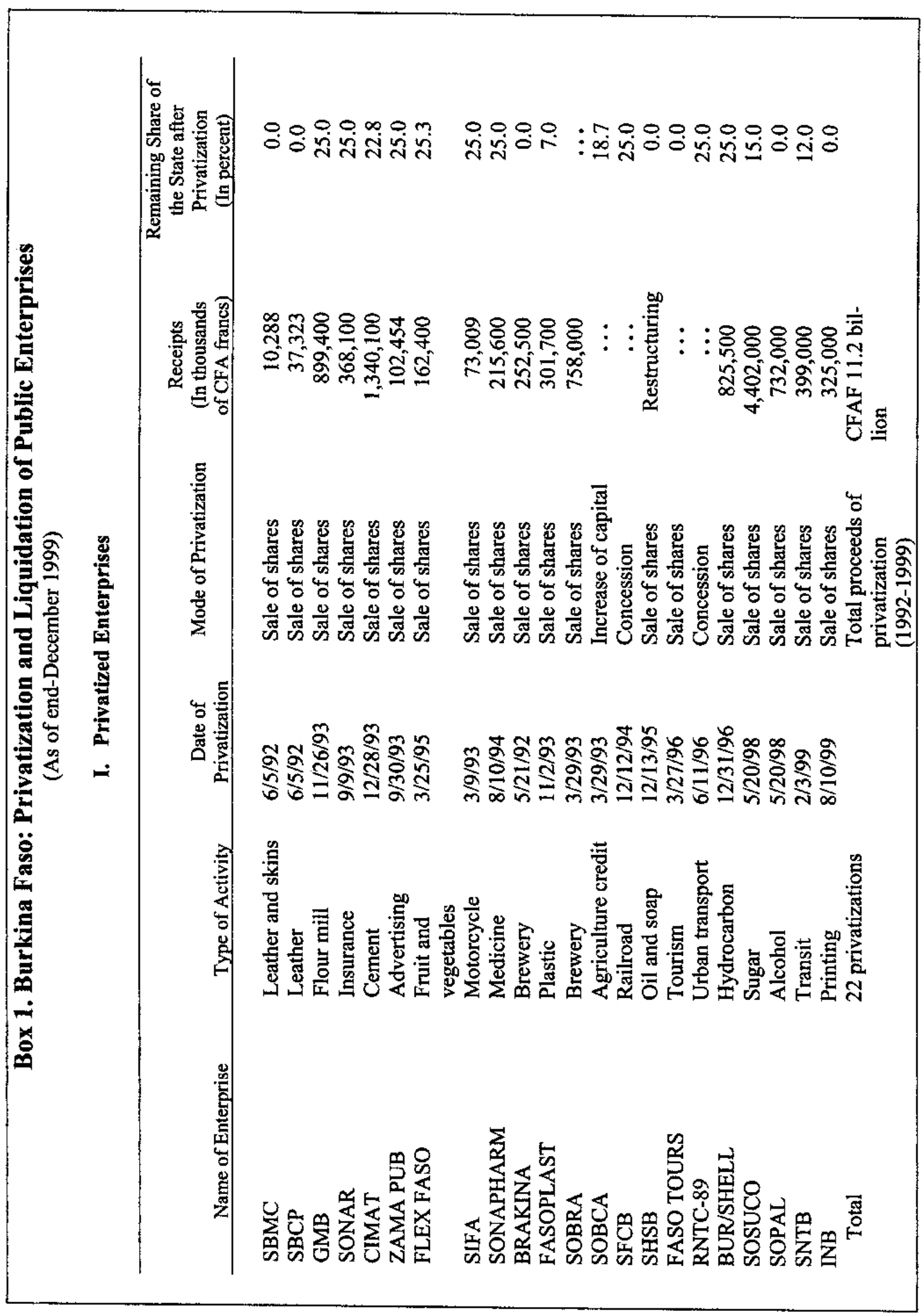




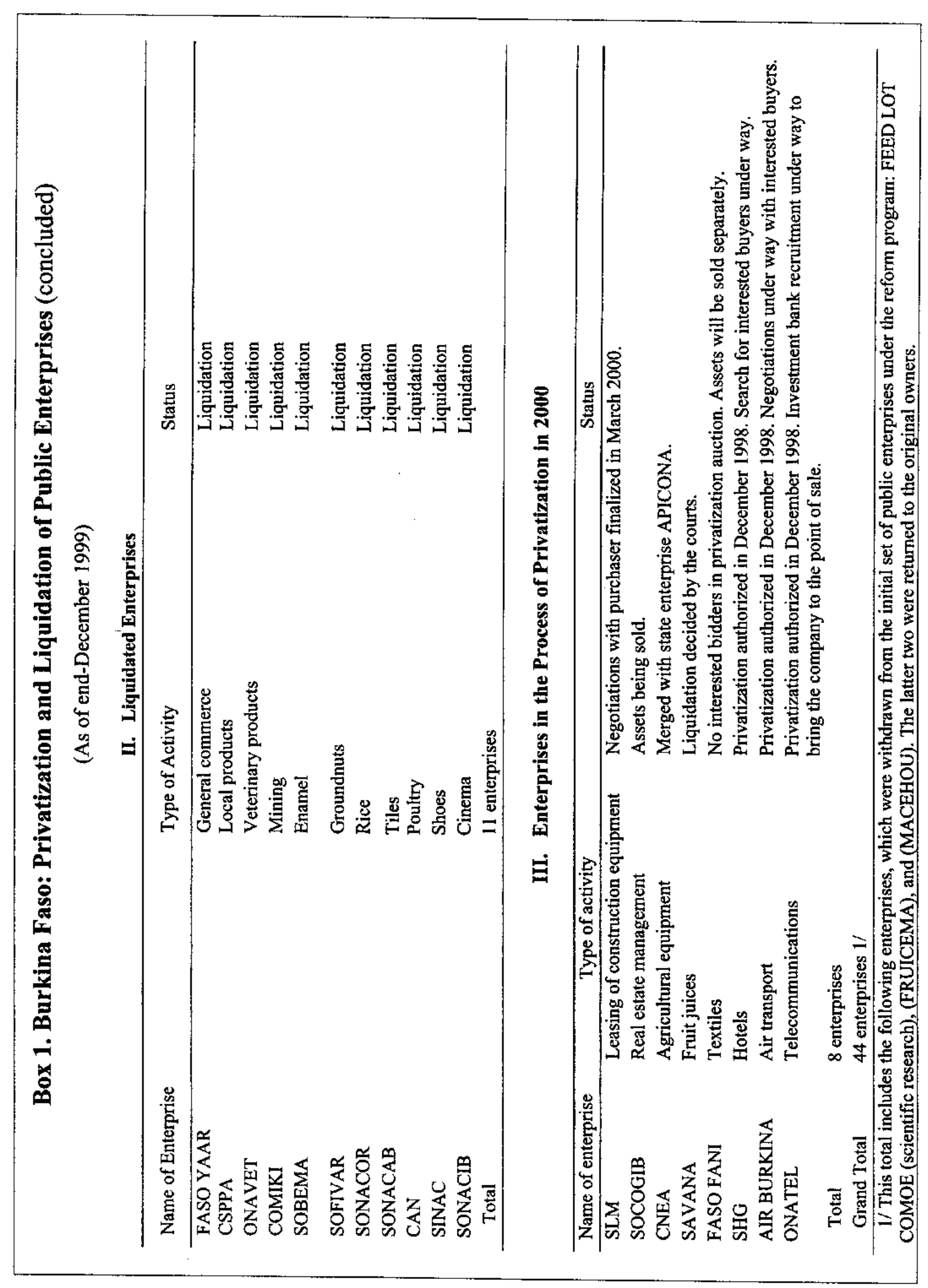


a noticeable increase in expenditure expressed as a percentage of GDP. As a result, the primary budgetary surplus narrowed from 1.1 percent of GDP in 1997 to 0.5 percent of GDP in 1998 and to 0.3 percent in 1999 , while the current primary budget surplus narrowed to 3.6 percent of GDP in 1998 from 4 percent in 1997 (3 percent in 1996), before widening to 4.5 percent in 1999 (Table 16). The overall fiscal deficit (commitment basis, excluding grants) narrowed from 10.2 percent of GDP in 1997 to 9.8 percent in 1998, and widened again to 12.3 percent of GDP in 1999, reflecting the implementation of the larger public investment program. On the financing side, there was a significant increase in foreign budgetary assistance in 1998 and 1999, while debt-service payments rose sharply in 1999. In all, net bank credit to government rose by 0.4 percent of the beginning-of period money stock in 1998 and by 3.5 percent in 1999 (Table 22).

\section{B. Government Revenue and Tax Administration Reform}

18. The phased introduction of the CET started in July 1998 with the reduction of the maximum customs/fiscal duty from 31 percent to 25 percent and the elimination of the 2 percent special intervention tax; these changes lowered the maximum overall tariff from 37 percent to 29 percent (Box 2). In April 1999, the authorities introduced the new product classification of the CET, with goods grouped into four categories with tariff rates of 0,5 , 10 , and 25 percent; the statistical tax was kept at 4 percent. The new product classification involved a significant reduction in the protection of many primary foodstuffs, including rice and sugar. As of January 2000, the authorities further lowered the maximum customs duty to 20 percent, and the statistical tax to 1 percent, thereby reducing the maximum external tariff rate to 21 percent. The tariff rates on imports of goods originating from the WAEMU were reduced by 60 percent in 1998 and 80 percent in 1999; they were fully eliminated on January $1,2000$.

\begin{tabular}{|c|c|c|c|c|c|c|c|c|c|c|c|c|}
\hline \multicolumn{13}{|c|}{$\begin{array}{l}\text { Box 2. Reform of External Tarif } \\
\text { (In percent) }\end{array}$} \\
\hline \multirow{3}{*}{$\begin{array}{l}\text { Customs rates/categories } \\
\text { External tariff rates }\end{array}$} & \multicolumn{3}{|c|}{ Until June 1998} & \multicolumn{3}{|c|}{ From July 1998} & \multicolumn{3}{|c|}{ From Jan. 1, 1999} & \multicolumn{3}{|c|}{ From Jan. 1, 2000} \\
\hline & I & II & III & I & II & $\overline{\text { III }}$ & I & II & III & I & II & III \\
\hline & & & & & & & & & & & & \\
\hline Customs/fiscal duty & 5 & 9 & 31 & 5 & 9 & 25 & 5 & 10 & 25 & 5.0 & 10.0 & 20.0 \\
\hline Statistical tax & 4 & 4 & 4 & 4 & 4 & 4 & 4 & 4 & 4 & 1.0 & 1.0 & 1.0 \\
\hline Special intervention tax & 2 & 2 & 2 & $\cdots$ & $\ldots$ & $\ldots$ & $\ldots$ & $\ldots$ & $\ldots$ & $\cdots$ & $\ldots$ & $\ldots$ \\
\hline Total & 11 & 15 & 37 & 9 & 14 & 29 & 9 & 14 & 29 & 6.0 & 11.0 & 21.0 \\
\hline Community solidarity levy (PCS) & 1 & 1 & 1 & 1 & 1 & 1 & 1 & 1 & 1 & 1.5 & 1.5 & 1.5 \\
\hline Intra-WAEMU tariff rates & & & & & & & & & & & & \\
\hline Local primary products & 0 & 0 & 0 & 0 & 0 & $\underline{0}$ & 0 & 0 & $\underline{0}$ & 0.0 & 0.0 & 0.0 \\
\hline $\begin{array}{l}\text { Eligible industrial products of } \\
\text { origin } \\
\text { Noneligible products of origin }\end{array}$ & 60 perc & $\begin{array}{l}\text { tpref } \\
\text { oints }\end{array}$ & nce & 60 perce & $\begin{array}{l}\text { prefe } \\
\text { oints }\end{array}$ & & 80 perc & $\begin{array}{l}\text { pref } \\
\text { oints }\end{array}$ & & 100 perc & $\begin{array}{l}\text { ent pre } \\
\text { points }\end{array}$ & rence \\
\hline
\end{tabular}

19. The cumulative fiscal revenue losses associated with the customs reform were significant. The revenue loss from import duties alone (customs duties, statistical tax and special intervention tax) was 0.4 percent of GDP in 1998 and an additional 0.4 percent of 
GDP in 1999 (Box 3). After including other external tariff revenue (including transfers from the WAEMU), the decline in external tariff revenue amounted to 0.9 percent of GDP over the 1998-99 period. A further decline of 0.7 percent of GDP is expected in 2000. The loss in external tariff revenue was more than offset by the revenue gains stemming from income tax collections, which rose by 0.6 percent of GDP in 1998-99, and from taxes on goods and services, which rose by 1.3 percent of GDP. ${ }^{3}$

\begin{tabular}{|c|c|c|c|}
\hline \multicolumn{4}{|c|}{$\begin{array}{c}\text { Box 3. External Tariff Revenue, 1997-1999 1/ } \\
\text { (In billions of CFA francs, unless otherwise indicated) }\end{array}$} \\
\hline & 1997 & 1998 & $19 \overline{199}$ \\
\hline Total external tariff revenue & 49.9 & 49.7 & 43.2 \\
\hline as a percentage of GDP & 3.6 & 3.2 & 2.7 \\
\hline Import duties & 43.0 & 43.8 & 40.4 \\
\hline as a percentage of GDP & 3.1 & 2.9 & 2.5 \\
\hline Customs duty & 32.6 & 32.1 & 29.0 \\
\hline Statistical tax & 10.4 & 11.7 & 11.4 \\
\hline Other import taxes & 5.9 & 4.7 & 1.6 \\
\hline Special intervention tax & 4.9 & 2.9 & 0.0 \\
\hline Special community tax (TPC +TCNA) & 1.0 & 1.8 & 1.0 \\
\hline Transfers from WAEMU $2 /$ & $\ldots$ & $\ldots$ & 0.6 \\
\hline Other taxes on international trade & 1.0 & 1.2 & 1.2 \\
\hline Contribution of livestock sector (on exports) & 0.6 & 0.7 & 0.6 \\
\hline Penalties & 0.4 & 0.5 & 0.6 \\
\hline \multicolumn{4}{|l|}{ Memorandum items: } \\
\hline Nominal GDP & 1,390 & 1,529 & 1,589 \\
\hline $\begin{array}{l}\text { Transfers to WAEMU and ECOWAS (community solidarity } \\
\text { levy) } 2 /\end{array}$ & 0.9 & 2.4 & 2.3 \\
\hline VAT on imports & 24.9 & 27.4 & 32.9 \\
\hline (as a percentage of GDP) & 1.8 & 1.8 & 2.1 \\
\hline \multicolumn{4}{|c|}{$\begin{array}{l}\text { 1/ Excluding taxes on goods and services paid in execution of public investment projects using checks issued by } \\
\text { the treasury. } \\
2 \text { / The WAEMU and the Economic Community of West African States (ECOWAS) have been collecting a } \\
\text { solidarity levy on extracommunity imports, respectively } 1 \text { percent (since January } 1,2000 \text { ) and } 0.5 \text { percent of } \\
\text { import value; the WAEMU transfers part of the receipts to member states to compensate for shortfalls in tariff } \\
\text { revenue owing to intracommunity trade. }\end{array}$} \\
\hline
\end{tabular}

${ }^{3}$ Revenue from income tax rose from 2.8 percent of GDP in 1997 to 2.9 percent in 1998 and 3.4 percent in 1999. Revenue from taxes on goods and services rose from 4.6 percent of GDP in 1996 to 5.4 percent in 1998 and 5.9 percent of GDP in 1999 (6.5 percent, including taxes paid by the treasury related to public investment activities). 
20. To some extent, the good performance of government revenue reflected the strength of economic activity. Following the bumper cotton crop of $1997 / 98$, corporate profits (including at the cotton ginning and marketing company, SOFITEX) were significant in 1998 , and this affected favorably the corporate tax collections of 1999 . Also, private consumption and the related value-added tax (VAT) receipts were boosted by two good agricultural crop years in 1998 and 1999 and the holding of special events in 1997-98 (including the soccer African Cup of Nations and the Organization of African Unity summit), as well as the wage increase in 1999 (see below). The good results achieved in 1998 and 1999 reflect also the application of the compensatory measures that were adopted to accompany the new classification of products under the CET (see Box 4). These measures included (i) the computerization from end-1999 of six additional customs offices; (ii) the elimination of the VAT exemptions on public contracts; and (iii) the enhanced monitoring of foreign-financed projects for which the taxes are paid by the treasury. In 1999, the special VAT procedures for importers of raw materials and for the enterprises registered under the Investment Code were eliminated, ${ }^{4}$ and, starting in June 1999, the VAT was applied to all public procurement contracts. ${ }^{5}$ In addition, the monitoring of large taxpayers was improved through tighter procedures for recovering taxes from defaulters, and progress was made in updating the computer systems of the tax administration. Finally, a new withholding tax of 2 percent on imports and purchases from wholesalers and producers, creditable against the business profit tax for registered taxpayers, was approved in 1999 and applied starting on January 1, 2000.

\section{Developments in Expenditure}

21. Both current primary expenditure and capital expenditure were broadly stable in 1998 as a percentage of GDP, before rising significantly in 1999. Current primary expenditure rose from 9.3 percent of GDP in 1997 to 9.5 percent in 1998, and 10.4 percent in 1999. Capital expenditure dropped slightly from 12.6 percent of GDP to 12.4 percent of GDP in 1998 before rising to 15.9 percent in 1999 .

\footnotetext{
${ }^{4}$ Since 1995, importers of raw materials and enterprises registered under the Investment Code had been allowed to not pay the VAT on imported goods at customs, but remained subject to the VAT on domestic sales.

${ }^{5}$ The previous procedures of pro forma invoices for the purchase from local suppliers under public procurement contracts was eliminated. Under the new procedure, the government pays the VAT to contractors on a timely basis as public works are executed and interim payments are made. The VAT on goods and services used as an input in public works are paid regularly by contractors, giving rise to a normal deduction entitlement.
} 


\section{Box 4. Main Fiscal Reforms, 1998-2000}

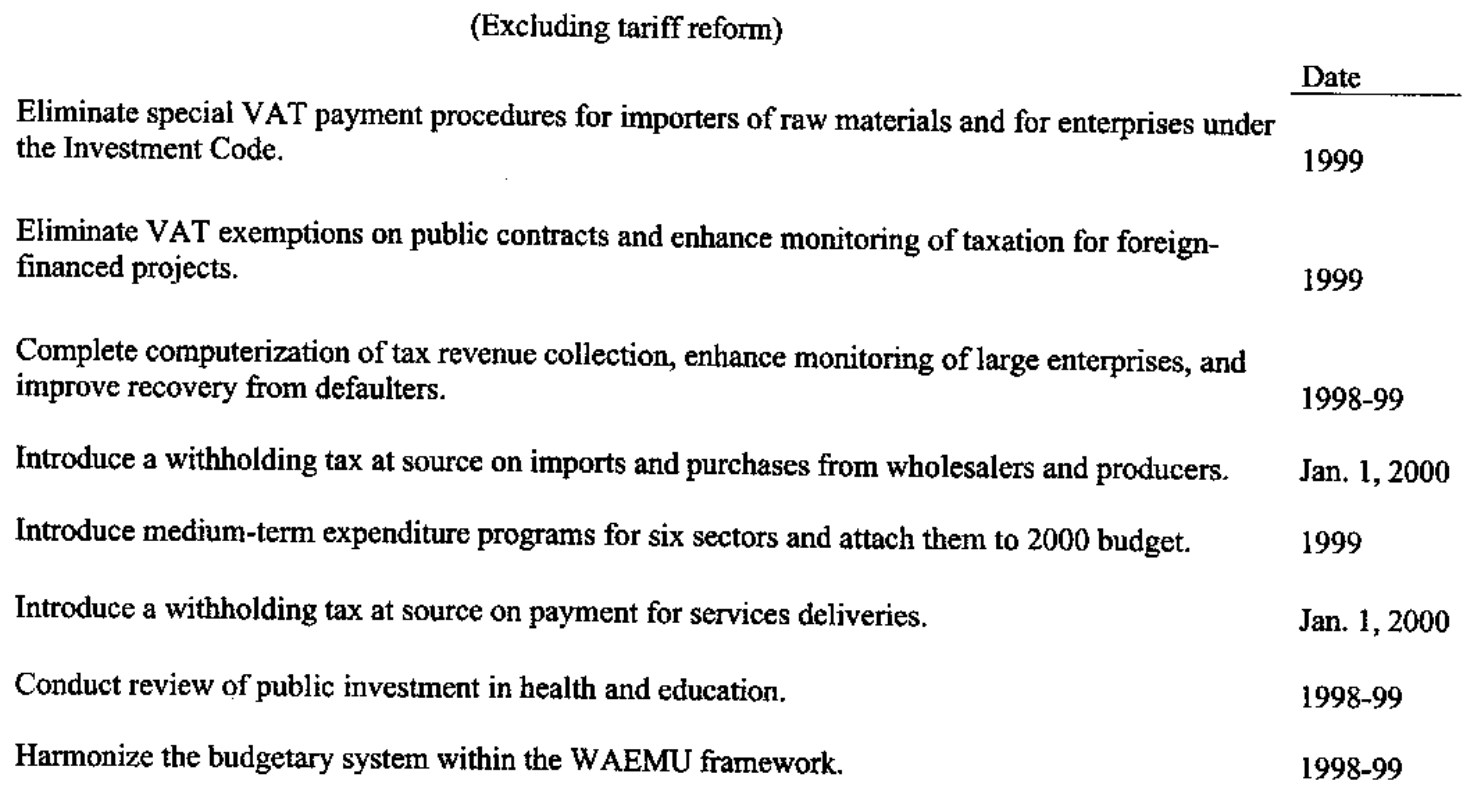

22. Starting in January 1999, the authorities implemented a broad civil service reform that included a merit-based promotion system (see Box 5) and a new wage scale. This scale is characterized by more steps grouped into three categories, and by a broader range of pay levels. The shift of the individual positions from the old to the new wage scale was carried out so as to permit an average pay increase on the order of 10 percent. The size of the increase was justified by the fact that no general wage increase had been granted since 1996. However, at 5.2 percent of GDP and 34.7 percent of government revenue in 1999, the size of the wage bill is in line with regional standards, and meets the convergence criterion of the WAEMU (wage bill less than 40 percent of revenue).

23. Larger allocations were made in 1998 and in 1999 for current spending and capital spending on health and education (Box 6). In the health sector, more resources were allocated to rural areas: about 600 health agents continued to be hired per year and larger provisions were made for the purchase of goods and services. In the education sector, with the opening of a fourth teachers' training school in 1998, the number of new teachers hired annually, which had increased to 900 per year in 1996 , rose to about 1200 per year. The share of current expenditure in health and education rose from less than 28 percent of total expenditure in 1996 to 32.6 percent of total expenditure in 1999. Even more marked was the rise in the share of health and education in the domestic budgetary contribution to the investment program from 10.3 percent in 1997 to 17.6 percent in 1999. One explanation for 
that increase is that the authorities, faced with a temporary slowdown in the disbursement of external aid, used their own resources to maintain the pace in building new schools and health centers.

\section{Box 5. Civil Service Reform}

The main elements of the civil service reform, which was approved by parliament in April 1998 and entered into force on January 1, 1999, are the following:

- A merit-based promotion system has been introduced, with the establishment in every ministry of a division in charge of human resources responsible for administering the system.

- The salary scales for permanent civil servants and contractual personnel have been widened, with more steps created. The steps are now grouped in three classes, with tight merit requirements established for passing from one class to the next (a grade of at least 8 out of 10 for the last ten years). A limit on the total amount of staff that can be promoted to the next class will be established every year.

- Only personnel in key functions dealing with policy issues and sovereignty functions will be hired with the status of permanent civil servants; the remainder, including in education and health, will be recruited as contractual staff.

Contractual staff members are regulated by a well-defined structure, in which different salary scales are defined according to educational qualifications, and salary progression is established on the basis of performance. Such staff members are hired for specific assignments, which can be modified by the administration based on requirements.

24. Significant progress was made in 1998 and 1999 in improving the monitoring of public expenditure in health and education, with the assistance of the main donors, including the European Union. Two public expenditure reviews of health and education prepared during 1999 were discussed in early 2000 with civil society and were used to update the government's Poverty Reduction Strategy. Moreover, three-year public expenditure plans for health and education, together with similar plans for four other sectors, were prepared in 1999 and attached to the budget for the year 2000. Notwithstanding these efforts, health and education standards remain low, and public expenditure in health and education needs to be made more cost-effective and better targeted to address the problems of the poor.

25. External financing of the public investment program accounted for 9.2 percent of GDP in 1998 and 11.7 percent of GDP in 1999. In particular, project grants amounted to 5.5 percent of GDP in 1998 and 7.4 percent in 1999. The foreign-financed component of the investment program was increased significantly to upgrade the facilities of health districts, construct housing for teachers and medical personnel, and build new classrooms, and health centers; however, the bulk of the increase in the foreign-financed portion of public investment programs is attributable to the acceleration in the implementation of large projects, such as the Ziga dam and some road infrastructure projects. 


\begin{tabular}{|c|c|c|c|c|}
\hline \multicolumn{5}{|c|}{$\begin{array}{l}\text { Box 6: Expenditure on Health and Education 1/ } \\
\text { (As a percentage of total budgetary expenditure) }\end{array}$} \\
\hline & 1996 & 1997 & 1998 & 1999 \\
\hline & \multicolumn{4}{|c|}{ (Current primary expenditure) } \\
\hline Health & 11.7 & 14.0 & 14.5 & 13.9 \\
\hline Primary education & 16.0 & 16.9 & 17.4 & 18.7 \\
\hline Total & 27.7 & 30.9 & 31.9 & 32.6 \\
\hline & \multicolumn{4}{|c|}{ (Of which: wages and salaries) } \\
\hline Health & 8.5 & 9.7 & 9.6 & 8.8 \\
\hline Primary education & 23.1 & 23.5 & 22.9 & 24.7 \\
\hline Total & 31.6 & 33.2 & 32.5 & 33.5 \\
\hline & \multicolumn{4}{|c|}{ (Investment on own resources) } \\
\hline Health & 5.5 & 4.8 & 7.8 & 10.3 \\
\hline Primary education & 6.9 & 5.5 & 5.3 & 7.3 \\
\hline Total & 12.4 & 10.3 & 13.1 & 17.6 \\
\hline & \multicolumn{4}{|c|}{ (Foreign-financed investment) } \\
\hline Health & 11.6 & 10.1 & 7.2 & 9.9 \\
\hline Primary education & 3.7 & 7.8 & 7.5 & 7.5 \\
\hline Total & 15.3 & 17.9 & 14.7 & 17.4 \\
\hline & \multicolumn{4}{|c|}{$\begin{array}{l}\text { (Total domestic expenditure, excluding } \\
\text { foreign-financed investment and debt) }\end{array}$} \\
\hline Health & 11.3 & 11.9 & 12.2 & 13.9 \\
\hline Primary education & 14.5 & 15.8 & 14.2 & 16.9 \\
\hline Total & 25.4 & 27.7 & 26.4 & 30.8 \\
\hline
\end{tabular}

26. Domestic arrears were reduced by about 1 percentage point of GDP in 1998-99; this total incorporates some offsetting of the cross debts between the government and the water, electricity, and telephone companies effected in January 1999, as well as the cost of the retroactive salary payments necessary to bring the administrative position of civil servants up to date, prior to the shift of civil servants to the new salary scales in 1999. Restructuring expenditure related to the liquidation and privatization of a number of public enterprises was relatively modest in 1998-99. Budgetary financing through grants and loans in support of the adjustment program rose markedly, from 1.9 percent of GDP in 1997 to 2.2 percent of GDP in 1998 and 2.3 percent in 1999.

27. External debt-service payments were relatively stable as a percentage of GDP in the 1996-98 period, but they rose significantly in 1999 (see Figure 2). This increase (essentially due to amortization payments) was related to payments made under new agreements concluded with foreign public works enterprises to settle disputes concerning past infrastructure investments. Similarly, the payments to service the domestic debt in 1999 rose sharply 
Figure 2. Burkina Faso: Distribution of Foreign-Financed Public Investment, 1996-1999 (as a percentage of gross domestic procuct)

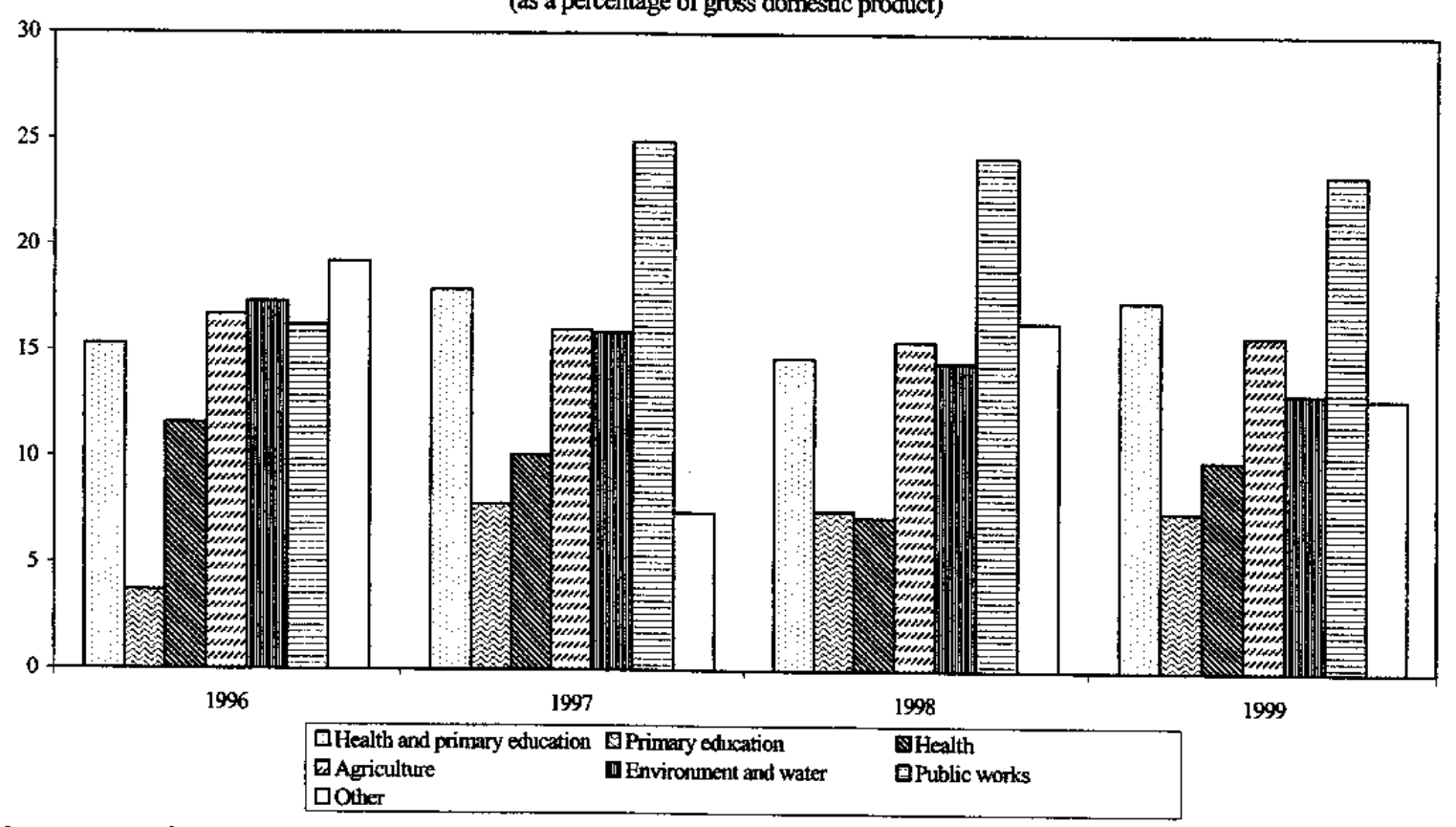

because of agreements reached with foreign public works enterprises to settle disputes concerning payments for past infrastructure investments; in addition, payments were made by the government in 1999 to refund to army personnel the portions of the salaries that had been withheld to establish a housing savings fund that never became operational. As discussed in Chapter V, Section B, the country is expected to reach the completion point under the original Heavily Indebted Poor Countries (HIPC) Initiative by June 2000. This will reduce substantially the debt service burden; the resources saved will be allocated mainly to the social sectors, and for other poverty reduction objectives. The government is committed to allocating to the social sectors resources made available by the debt relief under the HIPC Initiative.

\section{MONEY AND CREDIT}

28. Burkina Faso is a member of the West African Economic and Monetary Union (WAEMU) and shares a common currency, the CFA franc, and a central bank (Banque des États d'Afrique de l'Ouest, or BCEAO), with Benin, Côte d'Ivoire, Mali, Niger, Sénégal, Togo and Guinea-Bissau. The CFA franc was pegged to the French franc from 1948 to end1998; during that period, the parity was altered only once, in January 1994, when the CFA franc was devalued by 50 percent in foreign currency terms from CFAF 50 to CFAF 100 per French franc. Since January 1, 1999, the CFA franc has been pegged to the euro at the rate of CFAF 655.957 per euro. 


\section{A. Monetary Developments}

29. Following the devaluation of the CFA franc in 1994 and important structural reforms of the banking system, velocity ${ }^{6}$ declined from 4.8 in 1994 to 4.0 in 1996, and has remained stable at that level since that date. In 1999 , broad money grew by 6.5 percent, in line with nominal GDP (Table 22).

30. Credit to the private sector, after a continuous decline between 1991 and 1994 and a strong recovery in 1996 and 1997, grew modestly in 1998 and 1999 (3.0 percent and 2.1 percent growth at year's end in terms of beginning-of-period money stock, respectively). The relatively low level of credit activity at end-1999 reflects in part the late start of the financing of the 1999/2000 (October-September) cotton campaign. At the same time, credit to the government exceeded program targets at end-1999 (3.5 percent of the beginning-ofperiod money stock, against 1.4 percent in the program), owing to the higher-than-expected costs associated with the introduction of the new salary scale for civil servants, the larger reduction of domestic arrears, and the higher payment on external debt amortization. As a result, net domestic assets in percent of initial money stock rose by 9.1 over the course of the year.

31. The net foreign assets position of the banking system deteriorated slightly in 1999 ( -1.9 percent of initial money stock), after declining by 4.9 percent of initial money stock in 1998. The deterioration in the net foreign assets position in 1998 reflects the strong surge in imports and the worsening of the external current account, which was not offset by a corresponding improvement in net capital inflows. In 1999, the further decline in net foreign assets position of the central bank was partially offset by an improvement in the external position of the commercial banks.

\section{B. Monetary Policy}

32. Monetary policy is conducted within the framework of the West African Economic and Monetary Union (WAEMU). Since 1989, with the elimination of quantitative controls on bank credit and the unification of interest rate ceilings for all types of credit ${ }^{7}$-and, particulariy, since 1993-the BCEAO has been relying increasingly on indirect instruments to conduct monetary policy. In October 1993, the multiple money market rates fixed by the BCEAO were replaced by a single weekly rate applicable to all participating banks; this rate was either fixed by the BCEAO or determined by auction. At the same time, a legal reserve requirement was set at 1.5 percent of the sum of sight deposits and short-term loans. ${ }^{8}$ In parallel to these reforms, a regional interbank market was introduced in 1993, in which

${ }^{6}$ Defined as the ratio of GDP to the yearly average of end-of-month money stocks.

${ }^{7}$ The new ceiling was set at the discount rate (the highest level among the rates previously in place) plus 5 percent.

${ }^{8}$ The legal reserve requirement has remained unchanged since that date. 
interest rates are freely negotiated and operations conducted without the intervention of the central bank. Commercial bank interest rates were also progressively liberalized in the 1989-93 period, except for (i) the usury rate, ${ }^{9}$ (ii) the minimum rate on passbook deposits (savings deposits of less than CFAF lmillion), and (iii) the rate on deposits smaller than CFAF 5 million with a maturity of less than one year, which is set at the money market rate minus 2 percent (Tables 27 and 28). In July 1994, in order to mop up the large amount of liquidity in the banking system, the BCEAO securitized and sold consolidated claims that it held on governments on account of operations to restructure the banking system conducted in previous years. As a result, CFAF 440 billion of long-term bonds were issued-CFAF 9 billion by Burkina Faso-with a tax free interest rate of 5 percent. ${ }^{10}$ In August 1996, the system of two-way auctions, in which the central bank acted as intermediary between banks with excess liquidity and those in need of financing, was discontinued; subsequently, the BCEAO's operations to mop up liquidity took the form of short-term certificates issued through periodic auctions following the Dutch system. ${ }^{11}$

33. As of end-December 1999, Burkinabè commercial banks were holding government bonds in an amount equal to CFAF 68.9 billion (28 percent of their deposits). This total included CFAF 15.1 billion of bonds issued by the government of Burkina Faso with the central bank's guarantee, mostly related to bank restructuring operations, and CFAF 53.8 billion of bonds issued by other government of the monetary union. During 1999, Burkinabè banks remained very liquid and held an average monthly stock of reserves at the central bank of CFAF 11.7 billion ( 3 percent of end-of-period money stock); these reserves mainly took the form of BCEAO bills.

34. In the context of the renewed confidence following the 1994 devaluation, the central bank rediscount rate was lowered progressively from 14.5 in early 1994 to 10 percent at end1994, 6.5 percent at end-1996, and 6.0 at end-1997, before a slight increase of 25 basis points in mid-1998 (Table 25). After the smooth transition from the French franc to the euro peg in January 1999, the rediscount rate was again lowered to 5.75 percent in early 1999 , thus reducing the interest rate differential vis-à-vis France. The repurchase rate, which is always lower than the rediscount rate, followed a similar path: it declined from 7.0 percent at end-

\footnotetext{
${ }^{9}$ In October 1989 , the usury rate was set equal to the discount rate plus 5 percent; it was raised in October 1993 to twice the level of the discount rate. In July 1997, the Burkinabè National Assembly adopted a law that grants to the WAEMU Council of Ministers the authority to fix the level of the usury rate; currently, the level is set at 18 percent for banks and at 27 percent for other financial institutions (including credit unions and credit cooperatives).

${ }^{10}$ In order to increase the bonds' attractiveness, the BCEAO decided in September 1994 to guarantee their redemption at par any time, and to allow them to be used to fulfill minimum reserve requirements.

${ }^{11}$ Under this system, bidders pay or receive the interest rate they offer instead of the marginal rate.
} 
1994 to 6.0 percent at end-1996, and to 5.5 percent at end-1997. After a slight increase in the last half of 1998, it was lowered again to 5.25 percent in January 1999 (Table 25). The interest rate for advances on the money market (TMM) also declined from 5.5 percent at end-1994 to 4.96 percent at end-1997, and has since remained around that level (it stood at 4.95 percent at end-1999, Table 26). Following the resumption in June 1997, after a suspension of eight months, of the issue of BCEAO bills (with 28 days' maturity), their interest rate declined from 4.65 percent to 4.0 percent at end-1997. Issue of these bills was again suspended in the first semester of 1998 and between December 1998 and July 1999, as the central bank considered the liquidity situation to be broadly appropriate. In September 1999 , the rate of these bills stood at 4 percent.

35. Lending rates, which are freely determined, are estimated to have ranged between 8 percent and 9 percent for the best borrowers and the usury rate ranged between 12.5 percent from October 1996 to February 1997, 13 percent until end-July 1997, and 18 percent since August 1997 (Table 27). Increased competition in the banking sector has led to a decline in the lending rates for best borrowers in 1998-99, while time deposit rates are estimated to have ranged between 3.0 percent and 5.0 percent over the same period, with a tendency to increase (Table 28). Despite this narrowing in spread between lending and deposit rates, the spread remains relatively high reflecting the high level of risk in investments, and the difficulty in enforcing contractual guarantees. These factors also explain the large share of bank assets invested in liquid resources.

\section{Development of Credit Activity}

36. The evolution of credit activity in recent years has been driven by two parallel phenomena: (i) increased competition in the banking sector, mostly present in the country's two largest cities, Ouagadougou and Bobo Dioulasso, and catering to larger borrowers, mainly in the manufacturing and public works sectors; and (ii) the robust development of smaller credit unions, which provide financing for small projects in rural areas.

37. The traditional banking sector continued to strengthen in 1999. The solvency ratio, in particular, improved during the year for five of the seven banks, while all the banks observed the prudential ratio currently in force -4 percent-with significant margins. Five banks were already observing the new ratio of 8 percent, established by the regional central bank in mid1999 , with a phase-in period of two years. Competition in this sector increased significantly over the last two years, with the number of banks in Burkina Faso increasing from four to seven. This increased competition has led to a reduction of financial intermediation margins and, thus, of banks' profitability, particularly for the two banks that possess a network of local branches (the BIB, and the BICIA), and, hence, have to bear high fixed costs. The development of the banks' intermediation activity is hampered by what certain banks perceive as a restrictive regulatory environment and the widespread preference for cash as a means of transaction. On the regulatory side, medium- to long-term lending is limited by the short-term nature of most of the banks' resources, and by the BCEAO's prudential requirement that a minimum of 75 percent of the amount of medium- and long-term loans be covered by long-term resources. In this context, some banks are considering the introduction 
of new instruments to attract longer-term savings (such as Plans d'Épargne Logement). Another regulatory difficulty comes from the requirement that 60 percent of loans be eligible for rediscount by the central bank ("accord de classement"). This, in turn, requires the availability of audited balance sheets and income statements of the borrower for at least the past three years, a condition that is met by only a few borrowers. In order to increase the effectiveness of bank intermediation and reduce the widespread use of cash as in commercial transactions, banks are expanding services such as credit cards, and rapid wire transfers between countries of the monetary union.

\section{Balance of Payments and External Debt}

\section{A. Balance of Payments}

38. The deficit of the balance of payment current account, excluding official transfers, remained stable between 1996 and 1998 at about 14 percent of GDP (10 percent of GDP, including grants), but it widened to 16 percent of GDP in 1999 (12.6 percent of GDP, including grants). For the period 1996-98, a strong growth in exports was offset by a surge in imports, in particular for investment goods. In 1999, a sharp decline in export value explains most of the deterioration (Table 29) in the external current account.

39. With cotton accounting for one half to two thirds of total exports, the evolution of the trade and current account balances largely reflects changes in this key sector. Cotton seed production more than doubled between 1995 and 1997. However, with insect contamination reducing yields by about 30 percentage points in 1998 and farmers reducing planting because of increased risk aversion, cotton seed production declined from the record 1997/98 (October-September) campaign of 338,000 tons to 284,500 tons in $1998 / 99$ and 280,000 tons in 1999/2000. As a result, ginned cotton export volume decreased by 17 percent in 1999 and is expected to remain low in 2000 . The world price of cotton, which had been strong in 1997 and 1998, fell in 1999; however, the decline in the export unit price was limited to 16 percentage points, significantly less than the slide in the average international price, as a large share of exports had been sold through forward contracts while prices were still holding. Overall, the value of cotton exports in 1999 was 30 percent lower than in 1998 but still 69 percent higher than in 1996 (Table 31).

40. Gold production expanded less rapidly than anticipated, despite important foreign investments in this sector, because the strong decline in international prices slowed exploration and delayed production start-up. ${ }^{12}$ Nevertheless, the upgrading of the Pura mine was completed, and it is expected that, when operational, this mine could contribute 2 tons

\footnotetext{
${ }^{12}$ Exploration costs over the period 1996-98 are estimated to have averaged some CFAF 20 billion per annum. However, in 1999, in response to the decline in gold prices, most operators cut their expenses by half.
} 
per year, thereby doubling current production. ${ }^{13}$ Important reserves have also been identified in other mines, with more than half concentrated in about five sites. ${ }^{14}$ With a mining contract signed early in 2000 with Cluff Mining in Kalsaka, feasibility studies led by High River Gold and Ashanti Goldfields, respectively, completed in Taparko and Youga, and other contracts signed in Bombore and Inata, exports could increase further, as additional production in the range of 3-6 tons per year could be anticipated in the medium term, once the price recovers.

41. The strong growth in imports observed in 1996-98 (on average 16 percent per annum) reflects large, foreign-financed public investments, which increased from 8 percent of GDP in 1995 to 12 percent of GDP in 1999, as well as strong private investments in mining and construction. Food imports, which had risen substantially in 1998 as a result of poor cereal crops, returned to a normal level in 1999. However, in 1999, petroleum imports increased by almost 50 percent because of high international prices (Table 32).

42. Increasing outlays on freight and insurance, owing to rising imports, explain the bulk of the deficit on nonfactor services in 1995-99. Net private transfers, mainly workers' remittances, are estimated to have remained broadly stable. Concerning the capital and financial accounts, while the value of project grants and loans grew, as described above, external budgetary support was cut sharply from 5 percent of GDP to 2 percent in 1995, and remained around that level over the period 1996-99. The share of grants in total foreign financial assistance increased until 1997 but declined again in 1998-99. Amortization of external debt was substantially lower in 1996, as Burkina Faso benefited from a reduction in the stock of debt by Paris Club creditors; however, amortization increased in 1997-99, owing to repayments made to multilateral creditors for past loans starting to fall due and new agreements concluded with foreign public works enterprises to settle disputes concerning past infrastructure investments. Burkina Faso's contribution to the international reserves of the union was stable in 1996-97, but then declined over the period 1998-99.

43. The terms of trade deteriorated by 15 percent between 1995 and 1999 and are expected to decline further in 2000 . There has been no significant change in the CPI-based real effective exchange rate since 1996, except for minor fluctuations attributed to the impact of cereal production on domestic prices.

\section{B. External Debt}

44. The end-1999 stock of debt was estimated at US\$1,547 million, of which 85.6 percent was owed to multilateral institutions, mainly IDA and the African Development Fund,

\footnotetext{
${ }^{13}$ Large private companies account for the majority of the capital in the Pura mine, and the government's participation was reduced to 10 percent.

${ }^{14}$ Total reserves identified since 1995 amount to 8.8 million gold ounces (or 23 tons).
} 
3.8 percent to Paris Club creditors, and 10.6 percent to non-Paris Club creditors (Table 36). Debt to the IMF amounted to 7.8 percent of the total debt outstanding at end-1999.

45. With a grant element of the total stock estimated at 40 percent, the net present value (NPV) of the debt as of end-1999 was US $\$ 900$ million, or 292 percent of the average of exports of goods and nonfactor services in 1997-99. In 1999, the debt service corresponded to 23.3 percent of exports of goods and nonfactor services in the current year.

46. In September 1997, the IMF and the World Bank adopted a decision under which Burkina Faso was considered eligible for relief under the Initiative for Heavily Indebted Poor Countries (HIPC Initiative), and which provided that its debt would be reduced, by mid2000 , so as to attain a target of a NPV of debt-to-exports ratio of 205 percent. Under the enhanced HIPC Initiative, the total external debt reduction will be such as to bring the ratio to 150 percent-a dramatic improvement from the ratio as of end-1999, which, after application of all available debt-relief mechanisms, including from non-Paris Club creditors, was 280 percent. 


\section{THE COTTON SECTOR REFORM}

\section{A. Overview of the Cotton Sector in Burkina Faso}

47. Seed cotton output, estimated at 280,000 tons in 1999/2000 (October-September), is approximately at the same level as the previous campaign (284,500 tons)-significantly less, however, than the level of 338,000 tons recorded in 1997/98 (see table below). The very strong increase in production in the second half of the 1990s (from 151,400 tons in 1995/96 to 280,000 tons in $1999 / 2000$ ) reflects both better price incentives following the 1994 devaluation, the increase in international prices in 1994-98, and also major structural reforms as discussed below. Yields have increased from 807 kilograms per hectare in 1998/99, when there was a parasite attack, to $1,118 \mathrm{~kg} / \mathrm{ha}$ in $1999 / 2000$. Production of cotton fiber, at an average yield of 42 percent, is estimated at 119,000 tons. Except for a small quantity of about 4,000 tons sold locally, all cotton fiber is exported. Burkina Faso ranks fourth on the world market for the quality of its cotton. Data for the campaign 1999/2000 indicate that 61 percent of the fiber cotton sales are of the highest-quality cotton. ${ }^{15}$

48. Cotton producers, numbering approximately 200,000 , are still poorly endowed in technical know-how and in tools and machinery, although progress has been made in recent years. At present, about 5,000 producers out of 200,000, who account for 30 percent of total production, have relatively good equipment (tractors, ox-driven plows, etc.). The yield reached by the most efficient producers is $2-2.5$ tons per hectare, indicating that there is substantial potential to improve cultivation methods and, therefore, average yields. Cotton is rotated with cereals, mainly sorghum, maize, and millet. In 1999/2000, the cultivated area is estimated at 250,000 hectares and the yield at 1.1 ton of seed cotton per hectare. Yields vary widely; besides adequate rainfall, they depend on the selection of seeds, the use of tools and machinery, and the timely application of the appropriate chemicals (fertilizers and pesticides).

49. At present, cotton producers are grouped in about 6,500 producers' associations (Groupements des Producteurs de Coton or GPCs). These associations receive inputs (seeds and chemicals) from the cotton ginning and marketing company (SOFITEX) against collateral, which is the associations' cotton output. All seed cotton is sold to SOFITEX at a fixed producer price, set since 1996/97 at CFAF 160 per kilogram, plus a bonus paid at the end of the campaign (CFAF 25 per kilogram in 1998/99 and 1999/2000) representing the distribution of half of the before-tax profits of SOFITEX in the previous campaign. Cotton fiber is produced in 12 SOFITEX ginning plants located in various cotton regions. Except for the credit facility offered by SOFITEX, producers' associations have limited access to the formal financial sector, including the Caisse National du Credit Agricole (CNCA), the agricultural bank.

\footnotetext{
${ }^{15}$ Eighty percent of production meets the recognized standards for the three highest international categories.
} 


\section{Burkina Faso: Performance of the Cotton Sector, 1995/96 - 1999/2000}

\begin{tabular}{|c|c|c|c|c|c|}
\hline & $1995 / 96$ & $1996 / 97$ & $1997 / 98$ & $1998 / 99$ & $1999 / 2000$ \\
\hline & \multicolumn{5}{|c|}{ (In thousand of hectares) } \\
\hline \multirow[t]{2}{*}{ Cultivated areas } & 160.0 & 218.4 & 290.5 & 352.5 & 250.4 \\
\hline & \multicolumn{5}{|c|}{ (In kilogram per hectare) } \\
\hline \multirow[t]{2}{*}{ Yield } & 946.1 & 981.1 & $1,164.0$ & 807.0 & $1,118.0$ \\
\hline & \multicolumn{5}{|c|}{ (In thousands of metric tons, unless otherwise indicated) } \\
\hline \multicolumn{6}{|l|}{ Production and sales $1 / 2 /$} \\
\hline Yield cotton fiber/cotton seed & 0.42 & 0.42 & 0.42 & 0.42 & 0.42 \\
\hline Production of seed cotton & 151.4 & 214.3 & 338.0 & 284.5 & 280.0 \\
\hline Production of ginned cotton & 64.0 & 90.3 & 140.5 & 119.0 & 116.3 \\
\hline Exports & 64.0 & 89.4 & 139.0 & 118.5 & 115.0 \\
\hline Domestic sales & 1.0 & 0.6 & 1.0 & 0.3 & 0.7 \\
\hline Stocks & -0.4 & 0.0 & 0.0 & 0.0 & 0.0 \\
\hline \multirow{2}{*}{\multicolumn{6}{|c|}{ Unit values of ginned cotton }} \\
\hline & & & & & \\
\hline $\begin{array}{l}\text { Average t.o.b export price (Abidjan) } \\
\text { Average c.i.f export price }\end{array}$ & 775.0 & 834.6 & 874.0 & 697.0 & 623.0 \\
\hline $\begin{array}{l}\text { Average } c .1 . f \text { export price } \\
\text { Average fo.b export cost }\end{array}$ & 791.5 & 840.0 & 915.0 & 757.0 & 681.0 \\
\hline Average f.o.b export cost & 643.9 & 657.0 & 664.0 & 684.0 & 653.0 \\
\hline Average c.i.f export cost & 666.4 & 680.0 & 698.0 & 714.0 & 688.0 \\
\hline \multicolumn{6}{|c|}{ (In millions of CFA francs) } \\
\hline \multirow{4}{*}{$\begin{array}{l}\text { Financial operations } \\
\text { Income from sales } 3 / \\
\text { Profits }\end{array}$} & & & & & \\
\hline & 50,443 & 74,996 & 122,295 & 85,689 & 75,029 \\
\hline & 10,241 & 17,222 & 32,621 & 8,047 & 527 \\
\hline & & \multicolumn{4}{|c|}{ (In CFA francs per kilogram) } \\
\hline \multicolumn{6}{|l|}{ Memorandum items: } \\
\hline Producer price & 160 & 160 & 159 & 159 & 159 \\
\hline Bonus & 20 & 20 & 20 & 25 & 25 \\
\hline Variable cost per kilogram of fiber & 564 & 575 & 592 & 591 & 571 \\
\hline Fixed cost per kilogram of fiber & 79 & 82 & 72 & 93 & 81 \\
\hline Average profit per kilogram of fiber & 166 & 173 & 207 & 36 & 4 \\
\hline \multicolumn{6}{|c|}{ (In millions of CFA francs) } \\
\hline Taxes on value added & 2,800 & 3,300 & 4,000 & 3,000 & 1,700 \\
\hline Import duties & 4,700 & 5,500 & 6,000 & 6,000 & 2,000 \\
\hline
\end{tabular}

Source : Société des fibres textiles (SOFITEX).

1/ Crop and financial years run from October 1 to September 30.

2/ Current crop only.

$3 /$ Includes sales from previously accumulated stocks. 


\section{B. The Reform Strategy in the Cotton Sector}

50. The cotton sector has been liberalized at a gradual pace in recent years, with the emphasis placed on strengthening the role of the producers' associations; priority has been given to not disrupting a sector that is vital for the economy, maintaining support to farmers, and safeguarding the quality of cotton. At present, 95 percent of the approximately 200,000 cotton producers rely on the extension services of SOFITEX, which include the supply of high quality cotton seeds, appropriate fertilizers and pesticides, and technical assistance. SOFITEX guarantees the purchase of all cotton produced at a fixed producer price. This marketing channel represents an important privilege for the cotton producers, compared, for example, with the producers of rice, or other cereals, who could face difficulties finding outlets for their production. SOFITEX at present spends CFAF 300 million per year for extension services to producers. It pays the GPCs about CFAF 1 billion per year as commissions de Marché to remunerate them for services provided, such as weighing the seed cotton at the time of the purchase. It is the objective of SOFITEX that the GPCs gradually take over the responsibility of the extension services, which are crucial to increase yields.

51. With a view to increasing the participation of the private sector, 30 percent of SOFITEX's capital was sold to producers' association at end-1998. As 34 percent of SOFITEX is owned by the French company CFDT (Compagnie Francaise de Développement des Textiles), about 64 percent of its capital is now privately owned, with the state having become a minority shareholder ( 36 percent of the capital).

52. Besides establishing the producers' associations as the main actors in the cotton sector, the reform strategy aimed at helping these associations to adopt modern management and accounting systems, increasing the literacy rate of its members, and making available the services of SOFITEX counselors and technical staff, as well as the services of the research institutes of the Ministry of Agriculture. Out of the 6,500 GPCs, about 1,500 have accountants and follow good bookkeeping practices.

53. The distribution of fertilizers and pesticides is not the monopoly of SOFITEX, and private suppliers are free to operate. However, SOFITEX products enjoy a good reputation among farmers, as the company ensures quality control of the fertilizers and pesticides it distributes. Presently, 95 percent of the GPCs purchase fertilizers from SOFITEX, and 5 percent purchase from other suppliers. Prices of SOFITEX's fertilizers are generally lower. SOFITEX sells its fertilizers to producers on deferred payment; the cost of fertilizers is withheld at the moment of purchase of the next crop. For this credit operation, SOFITEX obtains a collective guarantee from the GPCs.

54. With a view to strengthening the production capacity of cotton producers, the authorities are undertaking a program with the assistance of the European Union, to identify different categories of producers, using as a main criterion the quantity of tools and machinery owned by farmers. The program would aim at supplying farmers with necessary tools in order to increase their production potential. 
55. The lack of access to financing is seen to be a major handicap facing cotton farmers. Moreover, SOFITEX is incurring high interest payments for financing fertilizer credits. The CNCA is not able to satisfy all financing requests; it refinances every year only a part of SOFITEX's input credit to the GPCs. The existing network of microfinance institutions, the Cooperative d'Epargne et de Credit, could complement the CNCA network if it would expand further into the cotton-producing areas. The major obstacle to the expansion of rural credit is the lack of credit guarantee, as farmers generally do not have land titles. Presently, the most important microfinance network operating in the cotton-producing regions, the Union Regionale des Caisses Populaires du Sud Ouest, has CFAF 1 billion in deposits and is expanding rapidly.

56. The liberalization strategy of the cotton sector has focused on the development of new cotton regions, where the private sector will be the main player. The private sector would operate according to requirements stipulated in the cahiers de charges (terms of reference) prepared by the Ministry of Agriculture, with a view to rationalizing investment, providing the same services to farmers as SOFITEX, and maintaining the quality of fiber cotton.

\section{Competitiveness and Profitability of the Cotton Sector}

57. On the basis of present estimates of the profitability of the sector, it appears that the cotton sector appears to be fully competitive. SOFITEX should make a small profit in $1999 / 2000$, despite the weakening, in the second half of 1999 , in international prices which has been partially reversed in the first quarter of 2000 . In 1998/99, profitability was greater, with before-tax profits of CFAF 3.7 billion. In order to avoid recording losses, despite the sharp decline in average export prices (16 percent on average between 1998/99 and 1999/2000), the company had to take determined measures to cut costs. Thus, in order to reduce transportation costs, SOFITEX adopted recently the system of weight (ton) per kilometer. Farmers now transport their seed cotton to collection centers, thereby reducing the transportation costs for SOFITEX.

58. In the same vein, with a view to improving efficiency and reducing costs, SOFITEX has started to distribute to farmers treated seeds, with a germination rate of about 90 percent, thus reducing the quantity of seeds from 40,000 tons to 20,000 tons. Both transportation costs and labor costs for growing cotton have been reduced by this measure. In addition, SOFITEX has decided to deliver seeds to cotton oil producers in bulk in order to save on the cost of packaging.

59. The competitiveness of the cotton sector could be enhanced further by productivityimproving measures, including the use of organic fertilizers, timely application of pesticides, and assistance for farmers in acquiring tools and machinery. Efforts are being made in collaboration with the different departments of the Ministry of Agriculture to bolster the extension services and increase technical assistance to cotton farmers. 


\section{Conclusion}

60. The reform strategy, in conjunction with the 1994 devaluation, has revived the cotton sector; however, further growth in the cotton sector continues to be constrained by a fixed exchange rate. In such a setting, terms of trade losses can be countered only by cost-cutting and productivity-improving measures. The reforms undertaken have enabled the sector to expand to a new output plateau of $280,000-338,000$ tons in the recent campaigns compared with an average production level of 145,000 tons in the early $1990 \mathrm{~s}$. Aware of the importance of the liberalization reforms, the government has decided to proceed so as not to disrupt a sector vital for the whole economy. 


\section{DEVELOPMENT OF DECENTRALIZED FINANCIAL SYSTEMS (DFSS)}

61. Following the adoption of the PARMEC law (regulating savings and loan cooperatives) ${ }^{16}$ and the related regulatory framework, all decentralized financial institutions in Burkina Faso are required to be registered by the Ministry of Finance, maintain accounting records, and submit at the end of each year information on the amount of savings collected and loans granted. In 1998, there were 136 registered microcredit institutions in Burkina Faso. Of these, 17 provided information to the central bank on a regular basis. As of end1998 , these 17 institutions had collected savings totaling CFAF 12 billion (6.1 percent of total private deposits) and provided individual or group loans totaling CFAF 11 billion ( 5.8 percent of total credit to the economy). The savings and credit of these 17 institutions have grown on average by 40 percent per annum since 1996 .

62. By far the most important microfinance institution is the Réseau des Caisses Populaires du Burkina (RCPB). Created in 1972, it now has a membership of 188,000 people and is expanding quickly. As of end-1999, the RCPB's deposits were valued at CFAF 11 billion and its lending at CFAF 7 billion. With about 20,000 loans, of an average size of about CFAF 355,000 (US\$540), the RCPB reaches some 51,000 clients $^{17}$ and offers the following types of credits: i) consumption lending, or financing of basic equipment; ii) housing credit; iii) trade credit; iv) agricultural input and equipment financing; and v) refinancing of village savings and loans associations managed by women. The allocation of credit is defined through a management process, whose internal control is guaranteed by limiting credit access to members; moreover, borrowers need to have saved an amount equivalent to at least onefourth of the loan requested. The only exception is the case of group lending to women's associations, which may borrow without having demonstrated savings capacity; provision of technical assistance in financial and social management usually accompanies financial services. Access to credit is graduated, with the first loan limited to CFAF 25,000 (US $\$ 38$ ), for a maximum of six months. The duration of the loan may progressively be extended to one or two years, and exceptionally for five years. Even with a good credit history, the maximum amount that can be obtained by one individual or one group is limited, depending on the type of credit: for example, CFAF 3 million (US\$4,500) for a consumption credit, and CFAF 10 million (some US $\$ 15,000$ ) for an agricultural credit. An annual interest rate of 10 percent and an additional fee of 2 percent for insurance are charged on a monthly basis. ${ }^{18}$

\footnotetext{
${ }^{16} \mathrm{Law} 59 / 1994 / \mathrm{ADP}$ on the regulation of mutual or cooperative savings and loans institutions (PARMEC).

${ }^{17}$ Many clients are organized in groups that save and borrow collectively.

${ }^{18}$ Although the RCPB's members have so far chosen to set a lending rate lower then the 27 percent usury rate, the WAEMU law could potentially impose a constraint on the expansion of credit in riskier and poorer areas.
} 
The profile of amortization depends on the type of loans; in the case of crop credit, for example, reimbursement is made at the end of harvest and sale. No interest is paid on deposits.

63. Access to financial services across the country has improved in recent years. However, about two-thirds of the RCPB's activities are still concentrated in the Ouagadougou area. The RCPB's experience with village savings and loans networks started in 1993, initially limited to the central region. Since 1998, however, the RCPB has decided to step up its outreach program, particularly in the western cotton-producing areas, where a now-liquidated network of savings and loans cooperatives (UCECB) had been active. In addition, other microfinance institutions provide services to areas not covered by the RCPB, for example, (i) the URC-Bam (Union Régionale des Cooperatives du BAM) operates in Kongoussi, and holds 10 percent of deposits and 6 percent of credits of the banking system; (ii) institutions only providing credit, such as PRODIA-AC (Projet de Développement Industriel et Artisanal) in Ouagadougou; and (iii) some development projects, which include a financial service component, and hold 6 percent of savings and 14 percent of credits of the banking system. The presence of microfinance institutions is weak in the eastern and south central regions, and some provinces in the northern regions also have insufficient access to financial services.

64. With a credit recovery rate of 92 percent (which was higher in 1996 and 1997), and with no interest paid on deposits, the RCPB is able to cover its operating costs. ${ }^{19}$ The Canadian nongovernmental organization, Développement International Desjardins (DID) has been for years the main supporter of the RCPB, providing technical assistance and investment financing. Since 1992, the DID has concentrated on financing, training and expansion into areas where provision of services is not profitable, but where the poverty reduction impact is expected to be particularly important. The European Union and the Netherlands are also helping to cover expansion costs with financing for investment expenditure and training. Since 1998, the RCPB has submitted its accounts for annual reviews by a certified auditing firm.

65. In January 2000, a service agency specializing in microfinance started operating in Ouagadougou, the Financial Innovation Center (CIF). It offers technical support to networks of savings and loans associations in West Africa that choose to pay the membership fee. The $\mathrm{RCPB}$ is the only Burkinabè institution that is a member of the CIF.

66. Prospects for further financial deepening certainly exist, which should contribute to the creation of revenue-generating activities in poorer regions and increase living standards through investment financing and consumption smoothing. In order to expand the network of existing decentralized financial systems (DFSs) and strengthen their financial discipline,

${ }^{19}$ Recent droughts caused delays in credit recovery, and some losses; however, the RCPB's financial situation appears to have remained stable. 
better integration with the banking system should be encouraged. ${ }^{20}$ In particular, the cotton ginning and export company (SOFITEX) and the agriculture bank (CNCA) could build on the network established at the local level by DFSs to expand services, reduce the unit cost of service delivery, and improve credit recovery. In fact, since September 1999, the CNCA has started developing a system to collect information on credit history for a number of village banks. In addition, SOFITEX and donors are providing management training to cotton farmers' associations.

${ }^{20}$ However, the development of DFSs is not the proper tool for poverty eradication, as the very poor cannot save, and lending to uneducated and isolated groups living in weatherdependent areas is not profitable and is particularly risky. Therefore, microfinance expansion would have to be complemented by targeted programs reserved for the poorest regions and the most vuInerable groups. 
Burkina Faso: Summary of the Tax System, January 1,2000

(All amounts in CFA francs)

\begin{tabular}{lcc}
\hline Tax & Nature of Tax & Exemptions and Deductions \\
\hline
\end{tabular}

1. Taxes on income and profits

1.1 Tax on individuals

1.1.1 Standard tax on income (impôt forfaitaire sur le revenu). Tax Code Articles 152 to 166 .

Eliminated through Ordinance No. 54/94 ADP of December 16, 1994

1.1.2 Noncommercial profits tax (impôt sur les bénéfices non commerciaux). Tax Code Articles 41 to 54 (BNC).

Tax levied on profits from the exercise of noncommercial professions. Based on previous year's profits. A witholding tax is levied on imports and wholesale purchases, which is creditable against the tax due.

1.1.3 Progressive income tax (impôt progressif sur les revenus de l'assistance technique française)

Started in 1990 in accordance with the FrancoBurkinabè cooperation agreement of February 4, 1986. Levied on French technical assistants' income.

1.1.4 Single progressive tax on wages and salaries (impôt unique sur les traitements et salaires). Tax Code Articles 55 to 74 .

Introduced in 1971, replacing previous specific taxes and the general income tax, and levied on all wages and salaries eamed during the current year. Withheld by employers on account of the treasury. To be paid 10 days after end of month.

No personal exemptions; a CFAF 100,000 exemption was abolished in 1972 (Loi No. 10/72/AN of December 23, 1972).

No exemptions.

All pensions are exempted. Al exemptions and deductions are spelled out in Article 56 (parliamentary indemnities severance pay, housing allowance, dependency allowance). Abatements are granted for dependents (up to seven).

Levied on rental income collected by owners of rental buildings (whatever their usage).

hotel rooms. sur les loyers).

1.1.6 Tax on real estate capital gains. Tax Code Articles 182 to 185.

Effective January 1978; levied on capital gains resulting from real estate sales.
25 percent reduction for new buildings during five years.
4 to 20 percent.

Progressive rate by income tranch ranging from 10 to 35 percent (cf. Loi. No. 0027/99/AN of $11 / 25 / 99)$.

Rates are 2 percent to 30 percent, payable by monthly installments.

Progressive rates from 0 percent to 35 percent.

15 percent of the capital gain. 


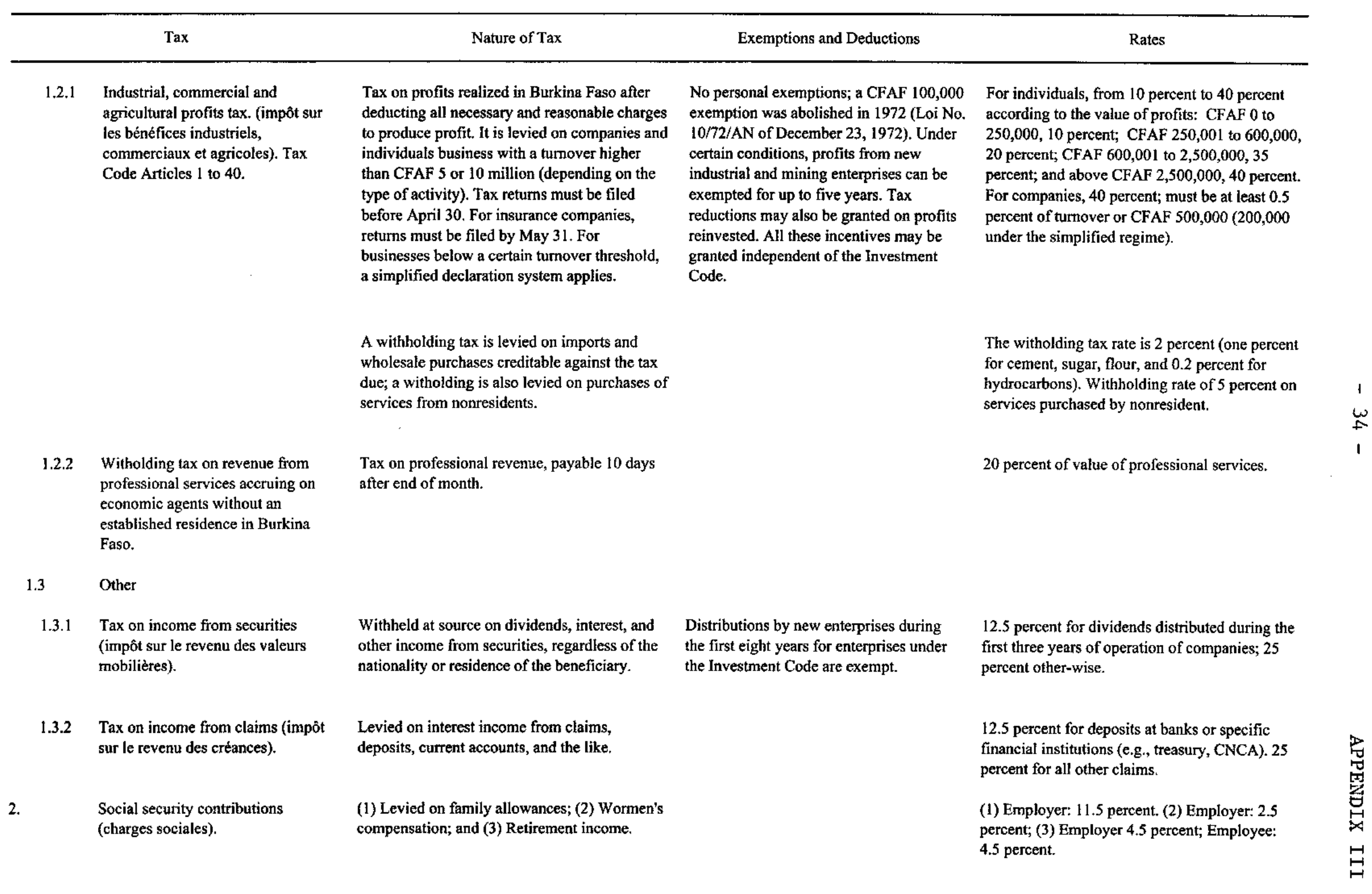


Burkina Faso: Summary of the Tax System, January 1, 2000

(All amounts in CFA francs)

\begin{tabular}{ccc}
\hline Tax & Nature of Tax & Exemptions and Deductions \\
\hline
\end{tabular}

\section{Payroll taxes}

3.1 Payroll and apprenticeship tax (tax patronale et d'apprentissage). Tax Code Articles 120 to 130

4. Taxes on property

4.1 Recurrent taxes on immovable property

4.1.1 Land tax (taxe de jouissance)

4,1,2 Residency tax (taxe de rési-dence). Tax Code Articles 219 to 235, amended by Ordinance No. 920016/PRES of 03/19/1992.

4.2 Estate, inheritance, and gift taxes

4.2.1 Tax on inheritances

4.2.2 Mortmain tax (taxe des biens de main morte). Tax Code Articles 199 to 210 .

Taxes on financial and capital transactions

4.3.1 Registration fees (droits d'enregistrement). Tax Code, various articles.

Tax on issues and registered acts. Levied also on contracts transferring various property and on rental contracts.
Tax on real estate.

Partial or complete exemption may be

Payable by employers, in principle not to be shifted to the employee in the form of lower wages or salaries. The base is the effective cash

payments for wages, salaries, and benefits.

Fifty percent is transferred to the National

Office for Employment Promotion.

Levied on all individuals for the use of dwellings. Proceeds accrue to local governments.

\section{Tax levied at the time of a declaration of} succession or of gift.

Tax on transfer of ownership at death or by git payable by stock companies. Assessed on annual rental value of property after usual deductions.

Military and police personnel deceased
4 percent on citizens of Burkina Faso; 8 percent on expatriates.
Individuals already exempted from standard tax on income.

Depends on region and zoning (commercial, industrial, residential, or rural). In Ouagadougou: CFAF $2,000-3,000 / \mathrm{m} 2$.

There are three schedules according to geographical zones. Rates take into account locality, and the equipment and construction material used in the dwelling. while on duty.

Government and companies with limited or general partnership are exempted. The following deductions are provided: 40 percent on annual rental value for houses; and 50 percent for factories.

\section{Reduced rate on mergers of companies.}

\section{Progressive rate.}

2.5 percent for houses made of mud or other local materials; 10 percent for houses made of concrete or stone.

Fixed or proportional and sometimes progressiv or various rates, depending on the nature of the transaction. 
(All amounts in CFA francs)

\begin{tabular}{cl}
\hline \multirow{2}{*}{ Tax } \\
\hline & $\begin{array}{l}\text { Real estate registration fee (droi } \\
\text { d'immatriculation et d'inscriptio }\end{array}$
\end{tabular}
foncière).

\section{Taxes on goods and services}

5.1 Value-added tax (VAT)

(taxe sur la valeur ajoutee). Tax

Code Articles 332 to 338 .
Replaces the tumover tax. Levied on the value of goods or services produced in Burkina Faso

by companies and non-salaried individuals.

Required use of registry machine for all sales

in cash by the registered TVA taxpayers (Loi

$036 / 97 / \mathrm{AN}$ of $12 / 4 / 97$ ). Withholding at the rate

of 18 percent on state and mixed enterprises

purchases from local suppliers. Tax to be paid

by the 20 th of the following month.
Deductions spelled out in Articles 325 and 18 percent, effective September 1, 1996. 331 of the Tax Code.
State and local communities fully exempt. Partial exemption for associations,

congregations and other entities

recognized by the state for construction

for social or cultural purpose.
Rates

Depending on the nature of the transaction.

25 percent for alcoholic beverages. 10 percent for non-alcoholic beverages.

25 percent for alcoholic beverages. 10 percent for non-alcoholic beverages.

10 percent.

5.2.3 Cola nuts (taxe sur les colas). Tax Code Articles 355 to 358 .
On customs value, as defined in Article 22 of Customs Code.
On customs value, as defined in Article 22 of Customs Code. boissons importées). Tax Code Articles 332 to 338 . 


\begin{tabular}{|c|c|}
\hline & $\operatorname{Tax}$ \\
\hline 5.2 .4 & Coffee and tea specific tax. \\
\hline 5.2 .5 & $\begin{array}{l}\text { Tobacco, cigars, and cigarettes (taxe } \\
\text { sur tabac, cigares et cigarettes). Tax } \\
\text { Code Articles } 352 \text { to } 354 \text {, quater. } \\
\text { Law } 50 / 95 / \text { ADP of } 11 / 15 / 95 \text {. }\end{array}$ \\
\hline 5.2 .6 & $\begin{array}{l}\text { Single tax on petroleum products } \\
\text { (taxe unique sur les produits } \\
\text { pétroliers (TUPP)), Law No. 005/94 } \\
\text { ADP of 03/11/1994. }\end{array}$ \\
\hline 5.3 & Profits of fiscal monopolies \\
\hline 5.3 .1 & $\begin{array}{l}\text { Tobacco (produits du monopole des } \\
\text { tabacs). Tax Code Articles } 522 \text { to } \\
574 \text {. }\end{array}$ \\
\hline 5.4 & Taxes on specific services \\
\hline 5.4 .1 & $\begin{array}{l}\text { Tax on insurance policies (taxe sur } \\
\text { les contrats d'assurance). Tax Code } \\
\text { Articles } 609 \text { to } 625 \text {. }\end{array}$ \\
\hline
\end{tabular}

Annual tax levied on insurance premiums.

On customs value, as defined in Article 22 of Customs Code.

Levied on the value of imported and locally produced goods. For imported products, tax is collected by customs. Producers file a return with the tax office before the 15 th of each

month.

Replaces all the taxes, except customs duties, previously levied on petroleum products.

\section{Abrogated.}

Articles 609 to 625 .

5.5 Taxes on use of goods and property, etc.

5.5.1 Business licenses (contribution des patentes). Tax Code Articles 238

278, amended by Ordinance No. 92 017/PRES of 03/19/1992.

Levied on all nonwage-earning individuals and corporations carrying on business in Burkina

Faso. Consists of a fixed charge and a variable

charge. Receipts accrue to local government.
Exemptions and Deductions

Rates

10 percent.

95 percent for imported tobacco; 13 percent for locally produced tobacco.

Rates vary according to nature of product and location of warehouse (Bobo Dioulasso or

Bingo).

Life annuity or life insurance contracts taken out by persons not habitually

Fire: 30 percent. Life: 8 percent. Travel by sea, river or air: 8 percent. Export credits: 0.25 residing in Burkina Faso and any contract percent. Public transportation vehicles: 24 covering a risk situated outside Burkina percent. Private cars: 10 percent. Other: 12 Faso are exempt, as are reinsurance percent. contracts.

Exemptions listed in Articles 249 and 271 of the Tax Code for government.

subsistence farmers, and agricultural

Fixed charge: depends on the category of business. Variable charge: 8 percent on rental value of business premises. 


\begin{tabular}{|c|c|c|c|c|}
\hline & $\operatorname{Tax}$ & Nature of Tax & Exemptions and Deductions & Rates \\
\hline 5.5 .2 & $\begin{array}{l}\text { Beverage sales licenses (licenses- } \\
\text { vente à la consommation). Tax Code } \\
\text { Articles } 367 \text { to } 371 \text {, bis. }\end{array}$ & $\begin{array}{l}\text { Applicable to establishments selling beverages } \\
\text { for consumption on the premises or carryout, } \\
\text { and to producers of dolo or bangui in the } \\
\text { communes. }\end{array}$ & & $\begin{array}{l}\text { CFAF } 18,000-150,000 \text { in annual fees, depending } \\
\text { on categories of establishment and locality (but } \\
\text { not on turnover). For producers of dolo or } \\
\text { bangui: CFAF } 24,000 \text { for Ouagadougou and } \\
\text { Bobo-Dioulasso, CFAF } 12,000 \text { elsewhere. }\end{array}$ \\
\hline 5.5 .3 & $\begin{array}{l}\text { Informal sector contribution } \\
\text { (contribution du secteur informel } \\
\text { (CSI). Tax Code Article 37, ter. }\end{array}$ & $\begin{array}{l}\text { Flat levy collected from the informal sector in } \\
\text { lieu of all taxes, excluding municipal taxes, and } \\
\text { the single tax on wages and salaries; it is } \\
\text { applied to businesses with a turnover of } \\
\text { between CFAF } 5 \text { and } 15 \text { million. Proceeds } \\
\text { accrue fully to local government budgets. }\end{array}$ & $\begin{array}{l}\text { Companies and.individuals already taxed } \\
\text { under BNC (1.1.2) and CSB (5.5.4) are } \\
\text { exempt. }\end{array}$ & $\begin{array}{l}\text { CFAF } 3,000-100,000 \text {, depending on class of } \\
\text { activity and locality. }\end{array}$ \\
\hline 5.5 .4 & $\begin{array}{l}\text { Beverage sector contribution } \\
\text { (contribution du secteur boisson } \\
\text { (CSB)) Tax Code Article 371, } \\
\text { quater. }\end{array}$ & $\begin{array}{l}\text { Flat levy collected in lieu of all taxes owed by } \\
\text { individuals or corporate entities selling locally } \\
\text { produced beverages. Proceeds from the CSB } \\
\text { accrue to the budget. The tax is withheld by the } \\
\text { producer and paid before the } 15 \text { of each month } \\
\text { to the tax office. }\end{array}$ & Producers exempt. & $\begin{array}{l}3 \text { percent on gross value (after tax) of purchases } \\
\text { made from producers by wholesalers. }\end{array}$ \\
\hline 6. & Taxes on international trade & & & \\
\hline 6.1 & Import duties & & & \\
\hline 6.1 .1 & $\begin{array}{l}\text { Customs duties (droits de douane). } \\
\text { Customs Code Articles } 8 \text { and } 12 \text {. }\end{array}$ & $\begin{array}{l}\text { Ad valorem tax levied on the c.i.f. value of all } \\
\text { imports. }\end{array}$ & $\begin{array}{l}\text { Exemptions for imports of some industrial } \\
\text { products originating in ECOWAS } \\
\text { countries, and, since } 1994 \text {, for } \\
\text { pharmaceutical goods. Preferential tariff } \\
\text { for products originating in the WAEMU: } \\
\text { Agriculture, livestock, and crafts: } 100 \\
\text { percent reduction; agreed industrial } \\
\text { products: } 100 \text { percent reduction; unlisted } \\
\text { industrial products: } 5 \text { percent reduction. }\end{array}$ & $\begin{array}{l}0,5,10 \text { and } 20 \text { percent, for the categories } 0,1,2 \\
\text { and } 3 \text { of goods defined in Regulation } \\
05 / 98 / \text { CM/WAEMU of July } 3,1998 .\end{array}$ \\
\hline 6.1 .2 & Statistical tax (taxe statistique) & Applied to all imports. & & 1 percent. \\
\hline
\end{tabular}


Burkina Faso: Summary of the Tax System, January 1, 2000

(All amounts in CFA franes)

\begin{tabular}{|c|c|c|c|c|}
\hline & Tax & Nature of Tax & Exemptions and Deductions & Rates \\
\hline 6.1 .3 & $\begin{array}{l}\text { Solidarity community levy } \\
\text { (prélevement communautaire de } \\
\text { solidarité (PCS)). }\end{array}$ & $\begin{array}{l}\text { Applied to all imports from outside the } \\
\text { UEMOA. }\end{array}$ & $\begin{array}{l}\text { Exemptions are similar to those for fiscal } \\
\text { duties. }\end{array}$ & 1 percent. \\
\hline 6.1 .4 & $\begin{array}{l}\text { Community levy (prélèvement } \\
\text { communautaire (PC)) }\end{array}$ & $\begin{array}{l}\text { Applied to all imports from outside the } \\
\text { ECOWAS. }\end{array}$ & $\begin{array}{l}\text { Exemptions are similar to those for ficsal } \\
\text { duties. }\end{array}$ & 0.5 percent. \\
\hline 6.2 & $\begin{array}{l}\text { Other taxes on international trade } \\
\text { and transactions }\end{array}$ & & & \\
\hline 6.2 .1 & Toll tax (taxe de péage). & $\begin{array}{l}\text { Levied on all imports. Receipts accrue to the } \\
\text { Chamber of Commerce. }\end{array}$ & $\begin{array}{l}\text { Petroleum products, and imports financed } \\
\text { by external aid are exempted. }\end{array}$ & $\begin{array}{l}\text { CFAF } 75 \text { per ton for rice, cement, and sugar; } \\
\text { CFAF } 150 \text { per ton for metal works; CFAF } 500 \\
\text { per ton for other imports; and CFAF } 3,000 \text { per } \\
\text { unit for vehicles. }\end{array}$ \\
\hline 7. & Other taxes & & & \\
\hline 7.1 & Stamp taxes (droit de timbre). & Levied on miscellaneous legal documents. & $\begin{array}{l}\text { The same exemptions as for registration } \\
\text { fees. }\end{array}$ & Depending on the nature of the document. \\
\hline
\end{tabular}

Sources: General Tax and Customs Directorates of the Ministry of Economy, Finance, and Planning. 
Table 1. Burkina Faso: Gross Domestic Product by Sector at Constant 1985 Prices, 1995-1999

\begin{tabular}{|c|c|c|c|c|c|}
\hline & 1995 & 1996 & 1997 & 1998 & $\begin{array}{r}1999 \\
\text { Est. }\end{array}$ \\
\hline & \multicolumn{5}{|c|}{ (In billions of 1985 CFA francs, unless otherwise indicated) } \\
\hline Primary sector & 329.7 & 354.1 & 349.5 & 368.7 & 380.3 \\
\hline Agriculture & 215.2 & 233.5 & 225.7 & 241.6 & 249.1 \\
\hline Livestock & 62.7 & 65.6 & 67.2 & 68.6 & 70.3 \\
\hline Forestry and fishing & 51.8 & 54.9 & 56.6 & 58.5 & 60.9 \\
\hline Secondary sector & 152.3 & 157.3 & 174.0 & 193.0 & 213.8 \\
\hline Mining and industry & 109.0 & 112.7 & 125.3 & 140.8 & 159.0 \\
\hline Electricity, gas, and water & 4.9 & 5.0 & 5.3 & 5.7 & 6.0 \\
\hline Construction and public works & 38.4 & 39.5 & 43.4 & 46.5 & 48.8 \\
\hline Tertiary sector & 338.8 & 360.8 & 389.5 & 405.5 & 432.5 \\
\hline Trade & 133.6 & 142.3 & 155.8 & 163.4 & 173.2 \\
\hline Transport & 36.4 & 38.8 & 42.4 & 44.5 & 47.8 \\
\hline Nonmarket services & 79.1 & 84.3 & 86.8 & 89.4 & 92.9 \\
\hline Other services & 89.6 & 95.5 & 104.5 & 108.2 & 118.6 \\
\hline GDP at factor cost & 820.8 & 872.1 & 913.0 & 967.2 & $1,026.6$ \\
\hline Import taxes and duties & 36.4 & 36.3 & 38.6 & 43.1 & 42.1 \\
\hline GDP at market prices & 857.2 & 908.4 & 951.6 & $1,010.2$ & $1,068.8$ \\
\hline \multicolumn{3}{|l|}{ Memorandum items: } & & & \\
\hline Nominal GDP & $1,175.5$ & $1,298.3$ & $1,390.1$ & $1,522.4$ & $1,588.6$ \\
\hline \multirow{2}{*}{ GDP deflator $(1985=100)$} & 137.1 & 142.9 & 146.1 & 150.7 & 148.6 \\
\hline & \multicolumn{5}{|c|}{ (Changes in percent) } \\
\hline Nominal GDP & 14.2 & 10.4 & 7.1 & 9.5 & 4.4 \\
\hline Real GDP & 4.0 & 6.0 & 4.8 & 6.2 & 5.8 \\
\hline GDP deflator & 9.8 & 4.2 & 2.2 & 3.2 & -1.4 \\
\hline Primary sector & 2.9 & 7.4 & -1.3 & 5.5 & 3.1 \\
\hline Secondary sector & 0.3 & 3.3 & 10.7 & 10.9 & 10.8 \\
\hline \multirow[t]{2}{*}{ Tertiary sector } & 2.0 & 6.5 & 7.9 & 4.1 & 6.7 \\
\hline & \multicolumn{5}{|c|}{ (In percent of GDP at factor costs) } \\
\hline Primary sector & 40.2 & 40.6 & 38.3 & 38.1 & 37.0 \\
\hline Secondary sector & 18.6 & 18.0 & 19.1 & 20.0 & 20.8 \\
\hline Tertiary sector & 41.3 & 41.4 & 42.7 & 41.9 & 42.1 \\
\hline
\end{tabular}

Sources: National Institute of Statistics and Demographics (INSD); and staff estimates. 
Table 2. Burkina Faso: Gross Domestic Product by Sector at Current Prices, 1995-1999

\begin{tabular}{|c|c|c|c|c|c|}
\hline & 1995 & 1996 & 1997 & 1998 & $\begin{array}{r}1999 \\
\text { Est. }\end{array}$ \\
\hline & \multicolumn{5}{|c|}{ (In billions of CFA francs) } \\
\hline Primary sector & 376.6 & 425.9 & 415.7 & 459.9 & 469.0 \\
\hline Agriculture & 182.3 & 212.8 & 197.3 & 224.5 & 228.8 \\
\hline Livestock & 116.8 & 127.7 & 129.5 & 138.8 & 140.7 \\
\hline Forestry and fishing & 77.5 & 85.4 & 88.9 & 96.7 & 99.5 \\
\hline Secondary sector & 289.9 & 308.4 & 351.6 & 399.7 & 424.5 \\
\hline Mining and manufacturing & 218.5 & 232.7 & 266.2 & 307.7 & 325.4 \\
\hline Electricity, gas, and water & 9.9 & 10.5 & 11.5 & 12.8 & 13.8 \\
\hline Construction and public works & 61.4 & 65.2 & 74.0 & 79.3 & 85.2 \\
\hline Tertiary sector & 437.5 & 489.3 & 539.6 & 576.7 & 606.6 \\
\hline Trade & 140.2 & 156.8 & 175.6 & 189.0 & 189.2 \\
\hline Transport & 44.6 & 49.9 & 55.9 & 60.3 & 65.0 \\
\hline Nonmarket services & 117.1 & 130.9 & 138.3 & 146.5 & 153.0 \\
\hline Other services & 135.6 & 151.7 & 169.9 & 180.9 & 199.4 \\
\hline GDP at factor cost & $1,104.0$ & $1,223.6$ & $1,306.8$ & $1,436.3$ & $1,500.0$ \\
\hline Import taxes and duties & 71.5 & 74.7 & 83.3 & 86.0 & 88.6 \\
\hline \multirow[t]{2}{*}{ GDP at market prices } & $1,175.5$ & $1,298.3$ & $1,390.1$ & $1,522.4$ & $1,588.6$ \\
\hline & \multicolumn{5}{|c|}{ (In percent of GDP at market prices) } \\
\hline Primary sector & 32.0 & 32.8 & 29.9 & 30.2 & 29.5 \\
\hline Agriculture & 15.5 & 16.4 & 14.2 & 14.7 & 14.4 \\
\hline Livestock & 9.9 & 9.8 & 9.3 & 9.1 & 8.9 \\
\hline Forestry and fishing & 6.6 & 6.6 & 6.4 & 6.4 & 6.3 \\
\hline Secondary sector & 24.7 & 23.8 & 25.3 & 26.3 & 26.7 \\
\hline Mining and manufacturing & 18.6 & 17.9 & 19.1 & 20.2 & 20.5 \\
\hline Electricity, gas, and water & 0.8 & 0.8 & 0.8 & 0.8 & 0.9 \\
\hline Construction and public works & 5.2 & 5.0 & 5.3 & 5.2 & 5.4 \\
\hline Tertiary sector & 37.2 & 37.7 & 38.8 & 37.9 & 38.2 \\
\hline Trade & 11.9 & 12.1 & 12.6 & 12.4 & 11.9 \\
\hline Transport & 3.8 & 3.8 & 4.0 & 4.0 & 4.1 \\
\hline Nonmarket services & 10.0 & 10.1 & 9.9 & 9.6 & 9.6 \\
\hline Other services & 11.5 & 11.7 & 12.2 & 11.9 & 12.5 \\
\hline GDP at factor cost & 93.9 & 94.2 & 94.0 & 94.3 & 94.4 \\
\hline Import taxes and duties & 6.1 & 5.8 & 6.0 & 5.7 & 5.6 \\
\hline GDP at market prices & 100.0 & 100.0 & 100.0 & 100.0 & 100.0 \\
\hline
\end{tabular}

Sources: National Institute of Statistics and Demographics (INSD); and staff estimates. 
Table 3. Burkina Faso: Implicit GDP Deflators by Sector, 1995-1999

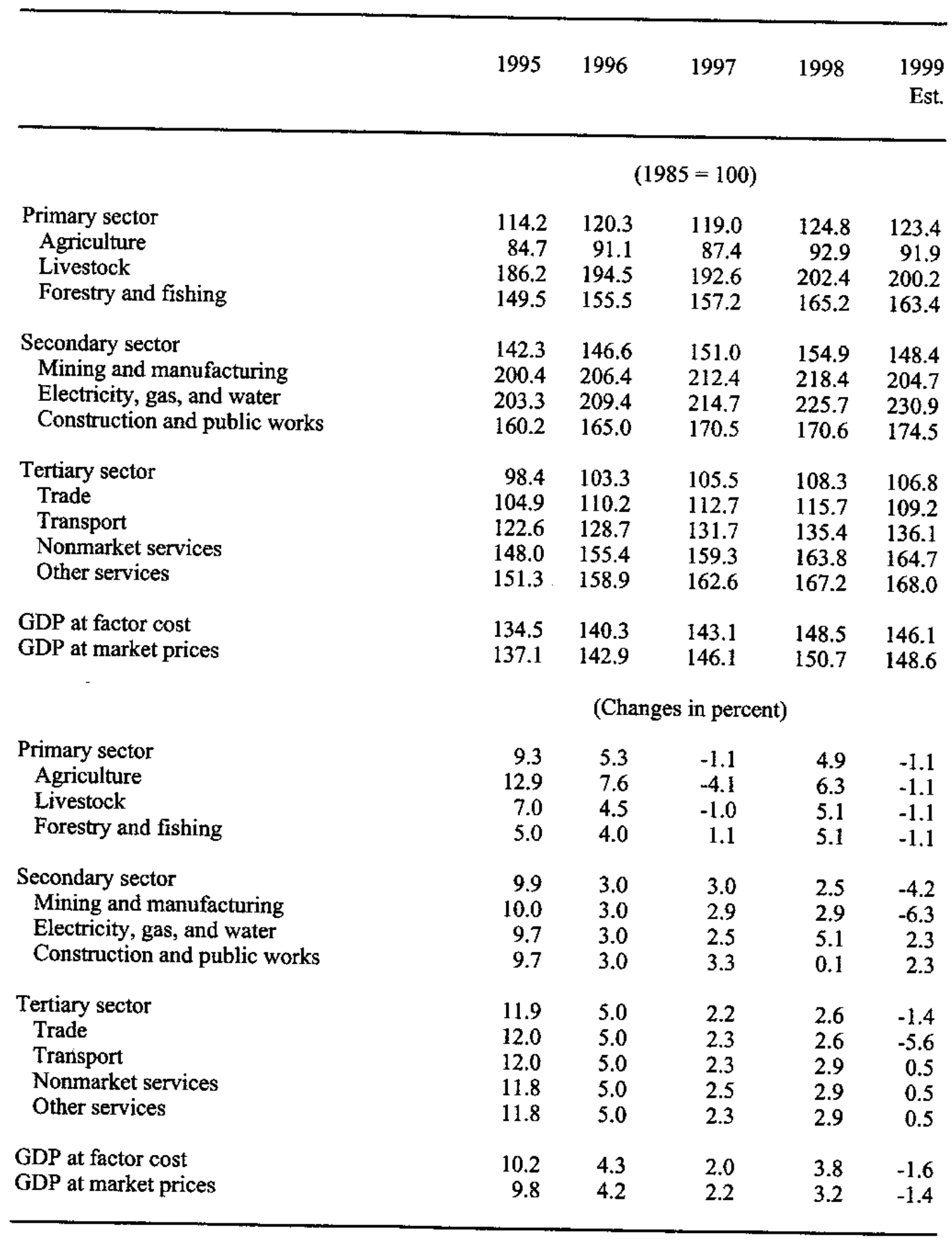

Sources: National Institute of Statistics and Demographics (INSD); and staff estimates. 
Table 4. Burkina Faso: Supply and Use of Resources in Current Prices, 1995-1999

\begin{tabular}{|c|c|c|c|c|c|}
\hline & 1995 & 1996 & 1997 & 1998 & $\begin{array}{r}1999 \\
\text { Est. }\end{array}$ \\
\hline & \multicolumn{5}{|c|}{ (In billions of CFA francs) } \\
\hline Resources & $1,508.2$ & $1,669.2$ & $1,775.0$ & $1,992.8$ & $2,055.7$ \\
\hline GDP at market prices & $1,175.5$ & $1,298.3$ & $1,390.1$ & $1,522.4$ & $1,588.6$ \\
\hline Imports $1 /$ & 332.6 & 371.0 & 385.0 & 470.5 & 467.1 \\
\hline Use of resources & $1,508.2$ & $1,669.2$ & $1,775.0$ & $1,992.8$ & $2,055.7$ \\
\hline Consumption & $1,074.9$ & $1,180.5$ & $1,239.1$ & $1,329.2$ & $1,433.7$ \\
\hline Public & 183.8 & 191.9 & 198.0 & 218.4 & 215.7 \\
\hline Private & 891.1 & 988.6 & $1,041.2$ & $1,110.7$ & $1,218.0$ \\
\hline Investment & 280.7 & 347.3 & 380.1 & 450.4 & 442.4 \\
\hline Fixed capital formation & 273.3 & 332.3 & 384.8 & 450.4 & 442.4 \\
\hline Public & 120.3 & 155.9 & 192.6 & 206.3 & 252.7 \\
\hline Of which: externally financed & 97.5 & 125.2 & 135.0 & 140.4 & 185.3 \\
\hline Private & 153.0 & 176.5 & 192.3 & 244.1 & 189.7 \\
\hline Change in inventories & 7.4 & 15.0 & -4.7 & 0.0 & 0.0 \\
\hline Exports $1 /$ & 152.6 & 141.4 & 155.8 & 213.2 & 179.6 \\
\hline Resource gap & 180.1 & 229.6 & 229.2 & 257.2 & 287.5 \\
\hline Gross domestic savings & 100.7 & 117.7 & 150.9 & 193.2 & 154.9 \\
\hline Net factors services & -5.7 & -4.0 & -7.8 & -7.0 & -7.8 \\
\hline \multirow[t]{2}{*}{ Private transfers } & 53.0 & 43.0 & 43.4 & 43.9 & 41.0 \\
\hline & \multicolumn{5}{|c|}{ (In percent of GDP) } \\
\hline Consumption & 91.4 & 90.9 & 89.1 & 87.3 & 90.2 \\
\hline Private consumption & 75.8 & 76.1 & 74.9 & 73.0 & 76.7 \\
\hline Public consumption & 15.6 & 14.8 & 14.2 & 14.3 & 13.6 \\
\hline Investment & 23.9 & 26.8 & 27.3 & 29.6 & 27.8 \\
\hline Private investment & 13.6 & 14.7 & 13.5 & 16.0 & 11.9 \\
\hline Public investment & 10.2 & 12.0 & 13.9 & 13.6 & 15.9 \\
\hline Gross domestic saving & 8.6 & 9.1 & 10.9 & 12.7 & 9.8 \\
\hline Private domestic saving & 3.9 & 3.2 & 3.6 & 5.6 & 2.5 \\
\hline Public domestic saving & 4.7 & 5.9 & 7.2 & 7.1 & 7.2 \\
\hline
\end{tabular}

Sources: National Institute of Statistics and Demographics (INSD); and staff estimates.

$1 /$ Goods and nonfactor services. 
Table 5. Burkina Faso: Production of Principal Crops, 1995/96-1999/2000

\begin{tabular}{|c|c|c|c|c|c|}
\hline & $1995 / 96$ & $1996 / 97$ & $1997 / 98$ & $1998 / 99$ & $\begin{array}{c}1999 / 2000 \\
\text { Est. }\end{array}$ \\
\hline & \multicolumn{5}{|c|}{ (In thousand of metric tons) } \\
\hline Cereals & $2,308.0$ & $2,481.8$ & $2,274.4$ & $2,656.5$ & $2,699.8$ \\
\hline Sorghum & $1,266.2$ & $1,254.0$ & $1,094.5$ & $1,202.5$ & $1,178.4$ \\
\hline Millet & 733.7 & 811.5 & 736.8 & 972.8 & 945.0 \\
\hline Maize & 212.5 & 293.7 & 331.9 & 377.8 & 468.9 \\
\hline Rice (paddy) & 84.0 & 111.8 & 98.6 & 89.0 & 94.2 \\
\hline Fonio & 11.6 & 10.8 & 12.6 & 14.4 & 13.3 \\
\hline Oilseed crops & 256.8 & 284.8 & 193.5 & 258.0 & 339.0 \\
\hline Groundnuts (shelled) & 173.3 & 211.6 & 146.0 & 206.2 & 271.4 \\
\hline Sesame & 7.8 & 13.2 & 7.5 & 7.8 & 12.6 \\
\hline Shea nuts & 75.7 & 60.0 & 40.0 & 44.0 & 55.0 \\
\hline Tubers and root crops & 299.9 & 324.4 & 258.5 & 441.1 & 413.1 \\
\hline Niébé and voandzou & 229.2 & 261.2 & 208.1 & 377.9 & 348.8 \\
\hline Yams & 64.0 & 49.2 & 36.4 & 45.5 & 43.0 \\
\hline Sweet potatoes & 2.7 & 10.0 & 10.0 & 13.6 & 17.3 \\
\hline Manioc & 4.0 & 4.0 & 4.0 & 4.0 & 4.0 \\
\hline Seed cotton & 150.5 & 214.3 & 338.0 & 284.5 & 280.0 \\
\hline \multirow[t]{2}{*}{ Fruit and vegetables } & 411.4 & 429.9 & 447.1 & 449.4 & 485.3 \\
\hline & \multicolumn{5}{|c|}{ (Changes in percent, unless otherwise indicated) } \\
\hline Cereals & -7.4 & 7.5 & -18.9 & 16.8 & 1.6 \\
\hline Sorghum & 2.7 & -1.0 & -12.7 & 9.9 & -2.0 \\
\hline Millet & -11.8 & 10.6 & -9.2 & 32.0 & -2.9 \\
\hline Maize & -39.3 & 38.2 & 13.0 & 13.8 & 24.1 \\
\hline Rice (paddy) & 37.7 & 33.1 & -11.8 & -9.7 & 5.8 \\
\hline Fonio & -29.2 & -6.6 & 16.2 & 14.5 & -7.8 \\
\hline Oilseed crops & -3.7 & 10.9 & -32.1 & 33.3 & 31.4 \\
\hline Groundnuts (shelled) & -11.1 & 22.1 & -31.0 & 41.2 & 31.6 \\
\hline Sesame & 363.1 & 70.6 & -43.4 & 4.0 & 61.5 \\
\hline Shea nuts & 8.0 & -20.7 & -33.3 & 10.0 & 25.0 \\
\hline Tubers and root crops & 72.7 & 8.2 & -20.3 & 70.6 & -6.3 \\
\hline Niébé and voandzou & 87.8 & 14.0 & -20.3 & 81.6 & -7.7 \\
\hline Yams & 75.9 & -23.2 & -26.0 & 25.0 & -5.5 \\
\hline Sweet potatoes & -76.1 & 270.4 & 0.0 & 36.2 & 27.0 \\
\hline Manioc & 0.0 & 0.0 & 0.0 & 0.0 & 0.0 \\
\hline Seed cotton & 3.8 & 42.4 & 57.7 & -15.8 & -1.6 \\
\hline Fruit and vegetables & 4.5 & 4.5 & 4.0 & 0.5 & 8.0 \\
\hline \multicolumn{6}{|l|}{ Memorandum items: } \\
\hline \multicolumn{6}{|l|}{ Cultivated area for cereals $1 /$} \\
\hline (in thousands of hectares) & $2,711.9$ & $2,711.4$ & $2,858.0$ & $3,279.6$ & $3,292.4$ \\
\hline Yield for cereals (tons per hectare) & 0.85 & 0.92 & 0.80 & 0.81 & 0.82 \\
\hline \multicolumn{6}{|l|}{ Cultivated area for seed cotton } \\
\hline \multicolumn{6}{|l|}{ Yield for seed cotton (tons per hectare) } \\
\hline Burkina Faso & 0.94 & 1.10 & 1.15 & 0.80 & 1.14 \\
\hline Benin & 1.27 & 1.25 & 0.93 & 1.11 & $\ldots$ \\
\hline Senegal & 0.80 & 0.70 & & $\ldots$ & $\ldots$ \\
\hline Cameroon & 1.24 & 1.17 & 1.12 & $\ldots$ & $\ldots$ \\
\hline
\end{tabular}

Sources: Ministry of Agriculture and Animal Resources; and staff estimates.

1/ Sorghum, millet, maize, rice, and fonio. 
Table 6. Burkina Faso: Producer Prices for Principal Crops, 1992/93-1999/2000 1/

(CFA francs per kilogram, unless otherwise indicated)

\begin{tabular}{|c|c|c|c|c|c|c|c|c|}
\hline$\cdot$ & $1992 / 93$ & $1993 / 94$ & $1994 / 95$ & $1995 / 96$ & $1996 / 97$ & $1997 / 98$ & $1998 / 99$ & $1999 / 2000$ \\
\hline Sorghum & 45.0 & 39.1 & 41.8 & 56.4 & 70.5 & 63.4 & 100.0 & 100.0 \\
\hline Millet & 45.0 & 41.9 & 44.9 & 60.6 & 75.7 & 68.1 & 115.0 & 115.0 \\
\hline Maize & 45.0 & 36.6 & 39.1 & 52.8 & 66.0 & 59.4 & 90.0 & 90.0 \\
\hline Rice (paddy) & 85.0 & 85.0 & 95.0 & 105.0 & 105.0 & 105.0 & 105.0 & 105.0 \\
\hline Fonio & 110.0 & 96.8 & 103.5 & 139.8 & 174.7 & 157.2 & 159.0 & 159.0 \\
\hline $\begin{array}{l}\text { Cotton seed, first grade } 2 / \\
\text { Average producer price } 2 /\end{array}$ & $\begin{array}{l}85.0 \\
83.3\end{array}$ & $\begin{array}{l}112.0 \\
108.7\end{array}$ & $\begin{array}{l}120.0 \\
111.1\end{array}$ & $\begin{array}{l}165.0 \\
164.3\end{array}$ & $\begin{array}{l}180.0 \\
176.8\end{array}$ & $\begin{array}{l}180.0 \\
176.8\end{array}$ & $\begin{array}{l}185.0 \\
176.8\end{array}$ & $\begin{array}{l}185.0 \\
181.5\end{array}$ \\
\hline Groundnuts (shelled, first grade) & 60.0 & 60.0 & 65.0 & 80.0 & 85.0 & 90.0 & 302.0 & 302.0 \\
\hline Shea nuts & 25.5 & 25.5 & 35.0 & 40.0 & 80.0 & 60.0 & 87.0 & 87.0 \\
\hline \multicolumn{9}{|l|}{ Memorandum items: } \\
\hline Cotton Liverpool price & 362.2 & 975.8 & $1,081.7$ & 908.3 & $1,019.1$ & 852.0 & 723.3 & 683.4 \\
\hline $\begin{array}{l}\text { Average cotton export price, c.i.f. } \\
\text { Average export price (in percent of }\end{array}$ & 391.8 & 658.6 & 829.7 & 791.5 & 840.0 & 915.0 & 757.0 & 681.0 \\
\hline $\begin{array}{l}\text { international price) } \\
\text { Average cotton producer price (in }\end{array}$ & 108.2 & 67.5 & 76.7 & 87.1 & 82.4 & 107.4 & 104.7 & 99.6 \\
\hline $\begin{array}{l}\text { percent of average export price) } \\
\text { Cotton producer price in other coun }\end{array}$ & 21.3 & 16.5 & 13.4 & 17.6 & 18.8 & 19.3 & 23.4 & 26.7 \\
\hline Benin & 95.0 & 100.0 & 140.0 & 165.0 & 200.0 & & $\ldots$ & $\ldots$ \\
\hline Cameroon & 84.4 & 128.1 & 154.1 & 174.1 & 179.6 & 179.5 & $\cdots$ & $\ldots$ \\
\hline Senegal & 100.0 & 110.0 & 150.0 & 170.0 & 170.0 & $\ldots$ & ... & $\cdots$ \\
\hline Côte d' Ivoire & 100.0 & 90.0 & 150.0 & 170.0 & 180.0 & $\ldots$ & $\ldots$ & $\cdots$ \\
\hline Mali & 85.0 & 85.0 & 125.0 & 125.0 & 158.9 & $\ldots$ & $\ldots$ & $\ldots$ \\
\hline
\end{tabular}

Sources: Ministry of Agriculture and Animal Resources until 1997/98; SIM/Sonagese for 1998/99; and staff estimates.

1/ Minimum producer prices fixed by the government until 1990. In 1991, prices of local products were freed.

2/ Including the premium redistributed to farmers equal to CFAF 20 in 1996/97-1997/98 and CFAF 25 in 1998/89 and 1999/2000. 
Table 7. Burkina Faso: Livestock, 1995-99

(In thousands of heads)

\begin{tabular}{lrrrrr}
\hline & 1995 & 1996 & 1997 & 1998 & 1999 \\
\hline Estimated population & 17,656 & 18,142 & 18,642 & 19,156 & 19,685 \\
$\quad$ Cattle & 4,346 & 4,433 & 4,522 & 4,612 & 4,704 \\
Sheep & 5,851 & 6,027 & 6,207 & 6,393 & 6,585 \\
Goats & 7,459 & 7,683 & 7,914 & 8,151 & 8,396 \\
Registered slaughtering & & & & & \\
Cattle & 788.6 & 910.8 & $1,029.0$ & $1,228.8$ & $\ldots$ \\
Sheep & 112.4 & 126.0 & 136.0 & 154.0 & $\ldots$ \\
Goats & 197.0 & 230.2 & 241.0 & 291.4 & $\ldots$ \\
& 479.2 & 554.6 & 652.0 & 783.4 & $\ldots$ \\
Exports of live animals & & & & & \\
$\quad$ Cattle & 390.2 & 396.7 & 426.0 & 478.0 & $\ldots$ \\
Other & 147.9 & 150.3 & 147.5 & 134.3 & $\ldots$ \\
& 242.3 & 246.4 & 278.5 & 343.7 & $\ldots$ \\
\hline
\end{tabular}

Sources: Ministry of Agriculture and Animal Resources; and staff estimates. 
Table 8. Burkina Faso: Industrial Production, 1993-99

\begin{tabular}{|c|c|c|c|c|c|c|c|c|}
\hline & Units & 1993 & 1994 & 1995 & 1996 & 1997 & 1998 & 1999 \\
\hline \multicolumn{9}{|c|}{ Foodstuff, beverages, and tobacco } \\
\hline Edible oils & Metric tons & 8,906 & 6,412 & 4,286 & 4,590 & 14,475 & 16,070 & 11,850 \\
\hline Nonedible oils & Metric tons & 0 & 0 & & $\ldots$ & $\ldots$ & $\ldots$ & , \\
\hline Sheanut butter & Metric tons & 1,758 & 574 & 286 & 0 & 0 & 316 & 121 \\
\hline Flour & Metric tons & 27,555 & 26,235 & 31,046 & 30,265 & 33,669 & 41,577 & 21,454 \\
\hline Pasta & Metric tons & 1,175 & 633 & 738 & 869 & 870 & 257 & 496 \\
\hline Sugar & Metric tons & 34,955 & 54,824 & 47,107 & 30,310 & 30,906 & 44,088 & 29,905 \\
\hline Beer & Thousand hectoliters & 258 & 287 & 372 & 435 & 460 & 501 & 387 \\
\hline Soft drinks & Thousand hectoliters & 85 & 86 & 115 & 142 & 168 & 195 & 155 \\
\hline Cigarettes & Millions of packets & 47 & 44 & 47 & 46 & 60 & 74 & 60 \\
\hline \multicolumn{9}{|c|}{ Textiles and leather } \\
\hline Spun & Metric tons & 350 & 306 & 398 & 390 & 243 & 130 & 21 \\
\hline Woven & Metric tons & 64 & 6 & 12 & 6 & 9 & 35 & 8 \\
\hline Printed fabric & Thousands of square meters & 4,618 & 5,957 & 5,298 & 5,098 & 4,141 & 3,818 & 1,462 \\
\hline \multicolumn{9}{|l|}{ Chemicals } \\
\hline Soap & Metric tons & 14,056 & 6,526 & 5,787 & 6,872 & 11,580 & 12,349 & 9,910 \\
\hline Matches & Cartons & 14,587 & $\ldots$ & $\ldots$ & 3,351 & 6,234 & 8,814 & 8,056 \\
\hline \multicolumn{9}{|l|}{ Miscellaneous } \\
\hline Bicycles & Units & 20,258 & 18,321 & 22,150 & 33,158 & 36,030 & 35,924 & 24,079 \\
\hline Mopeds & Units & 14,840 & 5,423 & 8,673 & 10,694 & 17,283 & 20,875 & 17,364 \\
\hline Tires & Thousands & 294 & 1,016 & 1,739 & 462 & 480 & 314 & 417 \\
\hline Inner tubes & Thousands & 1,924 & 2,292 & 2,660 & 2,245 & 2,604 & 1,755 & 2,540 \\
\hline
\end{tabular}

Source: National Institute of Statistics and Demographics (INSD). 
Table 9. Burkina Faso: Index of Industrial Production, 1993-99 1/

$$
(1990=100)
$$

\begin{tabular}{|c|c|c|c|c|c|c|c|c|}
\hline & Weights $2 /$ & 1993 & 1994 & 1995 & 1996 & 1997 & 1998 & 1999 \\
\hline Mining & 46 & 53.4 & 41.9 & 42.8 & 32.8 & 9.5 & 5.4 & 5.0 \\
\hline Food, beverages, and tobacco & 342 & 92.3 & 107.2 & 101.6 & 85.0 & 107.0 & 116.4 & 97.4 \\
\hline Baked goods & 67 & 108.1 & 105.7 & 124.6 & 119.0 & 140.5 & 83.1 & 43.7 \\
\hline Beverages and tobacco & 82 & 108.8 & 98.7 & 112.4 & 116.2 & 141.2 & 170.5 & 187.2 \\
\hline Other food industry & 192 & 77.4 & 112.2 & 88.8 & 59.7 & 75.8 & 102.8 & 74.1 \\
\hline Textiles & 208 & 64.9 & 76.1 & 84.2 & 78.5 & 90.6 & 123.1 & 84.9 \\
\hline Chemical industry & 140 & 73.7 & 34.2 & 76.5 & 62.6 & 77.6 & 73.9 & 95.0 \\
\hline Woodworking and metalworking & 73 & 85.8 & 69.7 & 61.8 & 95.9 & 130.9 & 148.3 & 87.7 \\
\hline Electricity, gas, and water & 191 & 114.2 & 114.1 & 120.3 & 122.9 & 131.2 & 133.8 & 122.1 \\
\hline Overall index & 1,000 & 85.5 & 86.3 & 89.9 & 86.1 & 100.4 & 112.0 & 93.6 \\
\hline
\end{tabular}

Source: Ministry of Trade, Industrial Development, and Mining; Directorate of Industrial Development and Handicraft.

1/ The index does not cover all the manufacturing activities and in particular new enterprises;

its weighting system based on 1990 leads to underestimating growth of overall industrial activity in recent years.

2/ Based on the average share in value added during 1990.

3/ Data for 1999 is provisional and is not yet fully consistent with national accounts data for that year. 
Table 10. Burkina Faso: Gold Production, 1993-99

(Fine gold in kilograms, unless otherwise specified)

\begin{tabular}{|c|c|c|c|c|c|c|c|}
\hline & 1993 & 1994 & 1995 & 1996 & 1997 & 1998 & 1999 \\
\hline Industrial gold-mining production & 2,296 & 1,637 & 1,619 & 1,063 & 1,088 & 1,091 & 869 \\
\hline Artisanal gold washing & 1,268 & 906 & 945 & 769 & 944 & 951 & 738 \\
\hline Industrial and semi-industrial & 1,028 & 731 & 674 & 294 & 144 & 140 & 131 \\
\hline Official exports of gold & 3,000 & 1,642 & 1,896 & 1,384 & 1,365 & 1,600 & 1,800 \\
\hline \multicolumn{8}{|l|}{ International gold price } \\
\hline (U.S. dollar per fine ounce; London) & 360 & 384 & 384 & 388 & 331 & 288 & 250 \\
\hline
\end{tabular}

Sources: Ministry of Energy and Mines (MEM); and National Institute of Statistics and Demographics (INSD). 
Table 11. Burkina Faso: Energy Indicators, 1993-99

\begin{tabular}{|c|c|c|c|c|c|c|c|}
\hline & 1993 & 1994 & 1995 & 1996 & 1997 & 1998 & 1999 \\
\hline & \multicolumn{7}{|c|}{ (In metric tons) $1 /$} \\
\hline \multicolumn{8}{|c|}{ Consumption of petroleum products $2 /$} \\
\hline Premium gasoline & 11,501 & 9,587 & 9,932 & 10,831 & 11,748 & 12,422 & 12,844 \\
\hline Regular gasoline & 53,406 & 54,804 & 61,095 & 65,356 & 71,238 & 72,999 & 75,545 \\
\hline Kerosene & 15,907 & 20,807 & 22,348 & 24,067 & 27,182 & 26,449 & 27,701 \\
\hline Diesel & 36,337 & 35,700 & 40,872 & 47,893 & 58,018 & 67,394 & 71,679 \\
\hline Light distillates & 33,008 & 27,745 & 29,691 & 34,955 & 29,190 & 37,692 & 56,135 \\
\hline Fuel oil & 30,588 & 30,017 & 22,275 & 14,205 & 45,550 & 40,258 & 22,852 \\
\hline Gas & 3,494 & 3,482 & 3,327 & 3,765 & 4,570 & 6,375 & 6,951 \\
\hline Total & 184,241 & 182,142 & 189,540 & 201,072 & 247,496 & 263,589 & 273,707 \\
\hline \multicolumn{8}{|c|}{ (In thousands of kilowatt-hours) } \\
\hline \multicolumn{8}{|l|}{ Electricity } \\
\hline Total production & 215,517 & 216,006 & 242,835 & 273,530 & 305,531 & 267,961 & $\ldots$ \\
\hline Of which : hydroelectric & 47,049 & 72,799 & 93,970 & 73,780 & 57,169 & $\ldots$ & $\ldots$ \\
\hline Distributed & 203,260 & 203,388 & 234,600 & 262,100 & 293,724 & 262,009 & $\ldots$ \\
\hline Total sales & 184,281 & 189,407 & 207,455 & 225,751 & 252,226 & 291,356 & $\ldots$ \\
\hline High voltage & 86,872 & 92,154 & 96,656 & 106,745 & 116,504 & 129,905 & $\ldots$ \\
\hline \multirow[t]{2}{*}{ Low voltage } & 97,409 & 97,253 & 110,799 & 119,006 & 135,722 & 161,451 & $\ldots$ \\
\hline & \multicolumn{7}{|c|}{ (In kilometers) } \\
\hline Length of distribution network & 3,141 & 3,184 & 3,351 & 4,073 & 4,797 & $\cdots$ & $\cdots$ \\
\hline Medium voltage & 895 & 807 & 956 & 1,438 & 1,889 & $\ldots$ & $\ldots$ \\
\hline Low voltage & 2,245 & 2,377 & 2,395 & 2,634 & 2,908 & $\ldots$ & $\ldots$ \\
\hline
\end{tabular}

Source: National Institute of Statistics and Demographics (INSD).

1/ Converted from cubic meters by using the following coefficients (in cubic meters per metric ton): gasoline, 1.36 ; kerosene, 1.26; diesel, 1.19; light distillates, 1.18; and fuel oil, 1.09.

2/ Excluding aviation and jet fuel. 
Table 12. Burkina Faso: Transport Activity, 1993-99 1/

\begin{tabular}{lllllllll}
\hline & 1993 & 1994 & 1995 & 1996 & 1997 & 1998 & 1999 \\
\hline
\end{tabular}

(In thousand of metric tons, unless otherwise indicated)

Rail traffic (freight)

\begin{tabular}{|c|c|c|c|c|c|c|c|}
\hline Domestic traffic & 7.0 & 4.0 & 2.0 & $\ldots$ & $\ldots$ & $\ldots$ & $\ldots$ \\
\hline International traffic & 239.7 & 214.0 & 183.0 & 386.0 & 513.0 & 475.7 & 372.8 \\
\hline Côte d'Ivoire to Burkina Faso & 187.8 & 165.0 & 160.0 & 351.0 & 459.0 & 427.2 & 333.3 \\
\hline Of which: cement & 29.9 & 45.0 & 54.0 & 84.0 & 5.0 & 2.5 & 4.6 \\
\hline flammable liquids & 45.3 & 19.0 & 19.0 & 47.0 & 68.0 & 22.8 & 27.4 \\
\hline Burkina Faso to Côte d'Ivoire & 51.9 & 49.0 & 23.0 & 35.0 & 54.0 & 48.5 & 39.5 \\
\hline Of which : cotton & 14.6 & 17.4 & 8.0 & 13.0 & 26.0 & 36.9 & 29.7 \\
\hline live animals (in thousands) & 46.0 & 79.1 & 6.0 & 14.0 & 18.0 & 11.6 & 9.8 \\
\hline Total traffic & 246.7 & 218.0 & $\begin{array}{r}185.0 \\
\quad(\mathrm{In}\end{array}$ & ... & ... & $\cdots$ & $\ldots$ \\
\hline ir traffic (Ouagadougou) & & & & & & & \\
\hline Commercial landings and takeoffs & 4.3 & 4.9 & 4.7 & 7.0 & 7.0 & $\ldots$ & $\ldots$ \\
\hline Passengers $2 /$ & 138.2 & 140.5 & 150.5 & 162.3 & 176.4 & $\ldots$ & $\ldots$ \\
\hline Freight & 6.7 & 5.9 & 6.1 & 4.9 & 7.0 & $\ldots$ & $\ldots$ \\
\hline Mail & 0.2 & 0.3 & 0.2 & 0.2 & 0.5 & $\ldots$ & ... \\
\hline
\end{tabular}

Sources: Ministry of Transport; and Railway Company (SCFP).

1/ 1996 data cover the period October 1, 1995 to September 30, 1996, while 1997 data cover the period October 1, 1996 to November 30, 1997.

2/ Excluding passengers in transit. 
Table 13. Burkina Faso: Prices of Petroleum Products, 1993-99

(In CFA francs per liter)

\begin{tabular}{|c|c|c|c|c|c|c|c|}
\hline & 1993 & 1994 & 1995 & 1996 & 1997 & 1998 & 1999 \\
\hline \multicolumn{8}{|c|}{ Import prices (c.i.f., Abidjan) } \\
\hline Premier gasoline & 59 & 80 & 74 & 87 & 102 & 79 & 89 \\
\hline Regular gasoline & 49 & 73 & 70 & 80 & 94 & 71 & 85 \\
\hline Kerosene & 57 & 82 & 73 & 93 & 89 & 69 & 85 \\
\hline Diesel & 47 & 80 & 71 & 96 & 95 & 70 & 77 \\
\hline \multicolumn{8}{|c|}{ Retail prices (Ouagadougou) 1/ } \\
\hline Premium gasoline & 285 & 395 & 395 & 393 & 400 & 397 & 410 \\
\hline Regular gasoline & 272 & 368 & 358 & 351 & 358 & 359 & 366 \\
\hline Kerosene & 160 & 160 & 160 & 160 & 200 & 205 & 210 \\
\hline Diesel & 240 & 300 & 300 & 297 & 297 & 284 & 285 \\
\hline Two-stroke mixture & 300 & 390 & 375 & 375 & 385 & 385 & 390 \\
\hline
\end{tabular}

Source: National Petroleum Company of Burkina (SONABHY).

1/ Retail prices in other locations differ from those in Ouagadougou. 
Table 14. Burkina Faso: Electricity Rates, 1993-99

(In CFA francs per kilowatt-hour)

\begin{tabular}{lrrrrrrr}
\hline & 1993 & 1994 & 1995 & 1996 & 1997 & 1998 & 1999 \\
\hline $\begin{array}{l}\text { High voltage 1/ } \\
\text { Peak hours }\end{array}$ & & & & & & & \\
$\quad$ Off-peak hours & 94 & 110 & 110 & 110 & 110 & 110 & 110 \\
& 43 & 51 & 51 & 51 & 51 & 51 & 51 \\
Low voltage & & & & & & & \\
$\quad$ Lighting, domestic use & & & & & & & \\
$\quad$ Low tariff 2/ & 68 & 73 & 73 & 73 & 73 & 73 & 73 \\
$\quad$ High tariff 3/ & 72 & 86 & 86 & 86 & 86 & 86 & 86 \\
Power unit & 108 & 130 & 130 & 130 & 130 & 130 & 130 \\
$\quad$ Peak hours & 57 & 70 & 70 & 70 & 70 & 70 & 70 \\
$\quad$ Off-peak hours & 100 & 120 & 120 & 120 & 120 & 120 & 120 \\
$\quad$ Public lighting & & & & & & & \\
\hline
\end{tabular}

Source: Nationale Electricity Company of Burkina (SONABEL).

1/ Hourly rate for 50 kilowatts and over.

2/ For subscriptions of 0.7 kilowatts and under.

3/ For subscriptions of 1.1 kilowatts and over. 
Table 15. Burkina Faso: Consumer Price Index, 1997-99

(1996 $=100$, unless indicated)

\begin{tabular}{lrrrr}
\hline & $\begin{array}{c}\text { New } \\
\text { Weights }\end{array}$ & 1997 & 1998 & 1999 \\
\hline Food, beverages, and stimulants & 3,392 & 104.6 & 114.4 & 107.3 \\
Clothing & 635 & 101.6 & 104.8 & 107.2 \\
Housing & 1,050 & 101.2 & 101.5 & 103.7 \\
Equipment & 666 & 102.0 & 104.7 & 104.7 \\
Health & 419 & 99.2 & 96.4 & 92.8 \\
Transport and communication & 1,557 & 101.4 & 101.0 & 101.4 \\
Cultural activities & 394 & 100.4 & 101.1 & 100.8 \\
Schooling & 340 & 101.5 & 106.3 & 109.8 \\
Hotels and restaurants & 996 & 105.6 & 115.3 & 119.9 \\
Other goods and services & 551 & 104.0 & 111.1 & 116.6 \\
Total & 10,000 & 102.9 & 108.0 & 106.8 \\
$\quad$ Annual percent change & & 2.3 & 5.0 & -1.1 \\
\hline
\end{tabular}

Source: National Institute of Statistics and Demographics (INSD). 
Table 16. Burkina Faso: Consolidated Operations of the Central Government, 1993-99

\begin{tabular}{|c|c|c|c|c|c|c|c|}
\hline & 1993 & 1994 & 1995 & 1996 & 1997 & 1998 & 1999 \\
\hline & \multicolumn{7}{|c|}{ (In billions of CFA francs) } \\
\hline Total revenue $1 /$ & 100.0 & 113.3 & 136.6 & 160.0 & 181.5 & 199.4 & 238.1 \\
\hline Current revenue & 99.4 & 113.3 & 136.6 & 160.0 & 181.3 & 199.2 & 238.0 \\
\hline Tax revenue & 72.6 & 104.0 & 127.3 & 149.0 & 166.4 & 183.5 & 222.2 \\
\hline Income and profits & 18.9 & 21.2 & 30.2 & 39.5 & 39.8 & 43.5 & 53.7 \\
\hline Domestic goods and services & 14.8 & 45.7 & 53.4 & 59.9 & 72.3 & 82.0 & 103.0 \\
\hline lnternational trade & 36.4 & 32.7 & 40.7 & 45.2 & 50.0 & 52.2 & 60.2 \\
\hline Other & 2.5 & 4.5 & 3.0 & 4.5 & 4.3 & 5.9 & 5.3 \\
\hline Nontax revenue & 26.8 & 9.4 & 9.3 & 11.0 & 14.9 & 15.6 & 15.8 \\
\hline Capital revenue & 0.6 & 0.0 & 0.0 & 0.0 & 0.1 & 0.2 & 0.1 \\
\hline Expenditure and net lending $2 /$ & 182.4 & 227.0 & 245.8 & 276.8 & 323.3 & 347.9 & 433.7 \\
\hline Domestic expenditure and net lending & 124.6 & 137.2 & 140.6 & 150.0 & 177.8 & 205.1 & 246.9 \\
\hline Excluding interest & 312.2 & 122.2 & 124.2 & 138.6 & 166.0 & 192.3 & 233.2 \\
\hline Of which: heatth and prinary education 3 / & 19.2 & 22.4 & 27,7 & 32.9 & 38.9 & 43.7 & 55.2 \\
\hline Wages and salaries & 52.2 & 58.2 & 61.6 & 64.7 & 67.7 & 72.0 & 82.6 \\
\hline Goods and services & 19.3 & 26.7 & 24.8 & 27.0 & 28.0 & 34.6 & 37.6 \\
\hline Interest payments & 12.4 & 15.0 & 16.4 & 11.5 & 11.7 & 12.7 & 13.7 \\
\hline Current transfers & 34.3 & 31.2 & 29.1 & 31.7 & 33.1 & 38.7 & 45.4 \\
\hline Budgetary contribution to investment & 8.8 & 9.2 & 11.6 & 16.9 & 39.7 & 47.6 & 67.3 \\
\hline Net lending $4 /$ & -2.5 & -3.0 & -3.0 & -1.7 & -2.5 & -0.6 & 0.3 \\
\hline $\begin{array}{l}\text { Primary balance (excluding foreign-financed } \\
\text { investment and restructuring operations) }\end{array}$ & -12.2 & -8.9 & 12.4 & 21.5 & 15.4 & 7.0 & 4.9 \\
\hline \multicolumn{8}{|l|}{ Prinary current balance (excluding } \\
\hline investment and restruchuring operations) & -3.4 & 0.3 & 24.0 & 38.4 & 55.1 & 54.6 & 72.2 \\
\hline Foreign-financed government investment & 54.6 & 62.5 & 97.5 & 125.2 & 135.0 & 140.4 & 185.3 \\
\hline Restructuring operations & 3.1 & 27.3 & 7.6 & 1.6 & 6.6 & 2.4 & 1.4 \\
\hline \multicolumn{8}{|l|}{ Overall surplus/deficit $2 /$} \\
\hline Exchuding grants and foreign-financed operations & -82.4 & -113.7 & -109.1 & -116.8 & -141.8 & -148.5 & -195.6 \\
\hline Change in payments arrears & 2.9 & -14.2 & -19.9 & -17.2 & -6.5 & -5.5 & -9.3 \\
\hline Domestic $5 /$ & $\ldots$ & -8.2 & .18 .6 & .17 .0 & -6.5 & -5.5 & -9.3 \\
\hline External & 2.9 & -6.0 & -1.4 & -0.2 & 0.0 & 0.0 & 0.0 \\
\hline Grants - & 43.2 & 75.4 & 88.0 & 109.1 & 97.8 & 103.7 & 141.1 \\
\hline Of which: project & 28.0 & 35.4 & 51.2 & 81.8 & 87.7 & 84.1 & 117.4 \\
\hline Overall deficit after grants (cash basis) & -36.3 & -52.5 & -41.2 & -24.9 & -50.5 & -50.3 & -63.8 \\
\hline Financing & 36.3 & 52.5 & 41.2 & 24.9 & 50.5 & 50.3 & 63.8 \\
\hline Foreign & 32.9 & 34.3 & 55.6 & 32.8 & 28.2 & 52.4 & 57.8 \\
\hline Drawings & 35.3 & 57.9 & 69.6 & 47.7 & 47.3 & 69.6 & 84.0 \\
\hline Of which : adjustment aid & 7.1 & 8.9 & 23.3 & 4.4 & 0.0 & 13.3 & 16.1 \\
\hline Amortization & -9.8 & -20.9 & -18.6 & .16 .0 & -19.1 & -20.0 & -26.2 \\
\hline Change in arnortization arrears & 4.7 & -11.4 & 0.0 & 0.0 & 0.0 & 0.0 & 0.0 \\
\hline Rescheduling $6 /$ & 2.7 & 8.5 & 4.6 & 1.1 & 2.8 & 2.8 & 4.2 \\
\hline Domestic & 3.4 & 18.4 & -14.4 & .7 .8 & 19.5 & -2.1 & 1.8 \\
\hline Benk & 4.1 & 20.7 & -9.9 & 1.0 & 21.9 & -6.7 & 11.6 \\
\hline Of which: IMF & 3.4 & 13.7 & 13.6 & 4.7 & 9.6 & 8.8 & 7.0 \\
\hline Nonbark & -0.7 & -2.3 & -4.5 & -9.7 & -3.1 & -1.9 & .13 .5 \\
\hline \multirow[t]{2}{*}{ Privatization revenuse } & $\cdots$ & $\ldots$ & $\cdots$ & 0.8 & 0.7 & 6.5 & 3.7 \\
\hline & \multicolumn{7}{|c|}{ (In percent of GDP; urless otherwise indicated) } \\
\hline Revenue & 12.6 & 11.0 & 11.6 & 12.3 & 13.1 & 13.1 & 15.0 \\
\hline Tax Reventse & 9.1 & 10.1 & 10.8 & 11.5 & 12.0 & 12.3 & 14.0 \\
\hline Domestic prinary expenditure and net lending & 14.1 & 11.9 & 10.6 & 10.7 & 11.9 & 12.6 & 14.7 \\
\hline Current expenditure (excluding net lending) & 14.8 & 12.7 & 11.2 & 10.4 & 10.1 & 10.4 & 11.3 \\
\hline Current primary expenditure (excluding net lending) & 13.3 & 11.3 & 9.8 & 9.5 & 9.3 & 9.5 & 10.4 \\
\hline Capital expenditure (excluding restructuring operations) & 8.0 & 7.0 & 9.3 & 10.9 & 12.6 & 12.4 & 15.9 \\
\hline Of which : foreign financed & 6.9 & 6.1 & 8.3 & 9.6 & 9.7 & 9.2 & 11.7 \\
\hline Overall surplus/deficit $1 /$ & -10.4 & -11.0 & -9.3 & -9.0 & +10.2 & -9.8 & -12.3 \\
\hline Primary balance & -1.5 & -0.9 & 1.1 & 1.7 & 1.1 & 0.5 & 0.3 \\
\hline Primary current balance & -0.4 & 0.0 & 2.0 & 3.0 & 4.0 & 3.6 & 4.5 \\
\hline GDP (in CFA billion) & 796.1 & $1,029.0$ & $1,175.5$ & $1,298.0$ & $1,390.1$ & $1,522.0$ & $1,589.0$ \\
\hline
\end{tabular}

Sources: Data provided by the Burkinabè authorities; and staff estimates.

I Starting in 1999, revenue inciudes taxes on goods and services paid in execution of public investment projects using checks issued by the treasury.

$2 f$ On a conmitment basis, excluding grants

$3 /$ Primary domestic expendinure on health and education excluding foreign franced investment and tax component.

4/ Excluding foreign-financed on-lending, including proceeds from privatization (-)

5/ Includes expenditures committed but not paid

6/ Includes contentious debt in negotiation with non-Paris Club creditors. 
Table 17. Burkina Faso: Economic Classification of Consolidated Government Expenditure, 1993-99

\begin{tabular}{|c|c|c|c|c|c|c|c|}
\hline & 1993 & 1994 & 1995 & 1996 & 1997 & 1998 & 1999 \\
\hline & \multicolumn{7}{|c|}{ (In billions of CFA francs) } \\
\hline Total expenditure and net lending & 182.4 & 227.0 & 245.8 & 276.8 & 323.3 & 347.9 & 433.7 \\
\hline Total expenditure & 184.9 & 230.1 & 248.7 & 278.6 & 325.8 & 348.5 & 433.4 \\
\hline Current & 118.2 & 131.0 & 132.0 & 134.9 & 140.5 & 158.0 & 179.3 \\
\hline Wages and salaries & 52.2 & 58.2 & 61.6 & 64.7 & 67.7 & 72.0 & 82.6 \\
\hline Goods and services & 19.3 & 26.7 & 24.8 & 27.0 & 28.0 & 34.6 & 37.6 \\
\hline Interest & 12.4 & 15.0 & 16.4 & 11.5 & 11.7 & 12.7 & 13.7 \\
\hline On extemal debt & 7.6 & 12.4 & 10.6 & 8.9 & 8.7 & 9.5 & 10.4 \\
\hline On domestic debt & 4.8 & 2.9 & 5.9 & 2.6 & 3.0 & 3.2 & 3.4 \\
\hline Transfers & 34.3 & 31.2 & 29.1 & 31.7 & 33.1 & 38.7 & 45.4 \\
\hline Capital & 66.7 & 99.1 & 116.7 & 143.7 & 185.3 & 190.4 & 254.1 \\
\hline Budget & 8.8 & 9.2 & 11.6 & 16.9 & 39.7 & 47.6 & 67.3 \\
\hline Financed by foreign grants & 28.0 & 35.4 & 51.2 & 81.8 & 87.7 & 84.1 & 117.4 \\
\hline Financed by foreign loans & 26.8 & 27.1 & 46.4 & 43.3 & 47.3 & 56.3 & 67.9 \\
\hline Capital transfer for banks restructuring & 3.1 & 27.4 & 7.6 & 1.7 & 10.5 & 2.4 & 1.4 \\
\hline \multirow[t]{2}{*}{ Net lending } & -2.5 & -3.0 & -3.0 & -1.7 & -2.5 & -0.6 & 0.3 \\
\hline & \multicolumn{7}{|c|}{ (In percent of GDP) } \\
\hline Total expenditure and net lending & 22.9 & 22.1 & 21.0 & 21.3 & 23.3 & 22.9 & 27.3 \\
\hline Total expenditure & 23.2 & 22.4 & 21.2 & 21.5 & 23.4 & 22.9 & 27.3 \\
\hline Current & 14.9 & 12.7 & 11.3 & 10.4 & 10.1 & 10.4 & 11.3 \\
\hline Wages and salaries & 6.6 & 5.7 & 5.3 & 5.0 & 4.9 & 4.7 & 5.2 \\
\hline Goods and services & 2.4 & 2.6 & 2.1 & 2.1 & 2.0 & 2.3 & 2.4 \\
\hline Interest & 1.6 & 1.5 & 1.4 & 0.9 & 0.8 & 0.8 & 0.9 \\
\hline Tranfers & 4.3 & 3.0 & 2.5 & 2.4 & 2.4 & 2.5 & 2.9 \\
\hline Capital & 8.4 & 9.6 & 10.0 & 11.1 & 13.3 & 12.5 & 16.0 \\
\hline \multirow[t]{2}{*}{ Net lending } & -0.3 & -0.3 & -0.3 & -0.2 & -0.2 & 0.0 & 0.0 \\
\hline & \multicolumn{7}{|c|}{ (In percent of total expenditure) } \\
\hline Total expenditure and net lending & 100.0 & 100.0 & 100.0 & 100.0 & 100.0 & 100.0 & 100.0 \\
\hline Total expenditure & 101.4 & 101.3 & 101.2 & 100.9 & 100.8 & 100.2 & 99.9 \\
\hline Current & 64.8 & 57.7 & 53.7 & 48.9 & 43.5 & 45.4 & 41.3 \\
\hline Wages and salaries & 28.6 & 25.7 & 25.1 & 23.4 & 20.9 & 20.7 & 19.0 \\
\hline Goods and services & 10.6 & 11.7 & 10.1 & 9.8 & 8.7 & 9.9 & 8.7 \\
\hline Interest & 6.8 & 6.6 & 6.7 & 4.2 & 3.6 & 3.7 & 3.2 \\
\hline Transfers & 18.8 & 13.7 & 11.9 & 11.5 & 10.2 & 11.1 & 10.5 \\
\hline Capital & 36.6 & 43.6 & 47.5 & 52.1 & 57.3 & 54.7 & 58.6 \\
\hline \multirow[t]{2}{*}{ Net lending } & -1.4 & -1.3 & -1.2 & -0.9 & -0.8 & -0.2 & 0.1 \\
\hline & \multicolumn{7}{|c|}{ (In billions of CFA francs) } \\
\hline \multicolumn{8}{|l|}{ Memorandum items: } \\
\hline Technical assistance-related expenditure & 7.3 & 12.6 & 14.6 & 15.5 & 16.4 & 16.1 & 15.8 \\
\hline Financed by foreign grants & 2.0 & 2.7 & 6.9 & 8.1 & 8.6 & 8.4 & 8.3 \\
\hline Financed by foreign loans & 5.3 & 9.9 & 7.7 & 7.4 & 7.8 & 7.6 & 7.5 \\
\hline
\end{tabular}


Table 18. Burkino Faso: Public Investment Program, 1993-99

(In billions of CFA francs)

\begin{tabular}{|c|c|c|c|c|c|c|c|}
\hline & 1993 & 1994 & 1995 & 1996 & 1997 & 1998 & 1999 \\
\hline Government & 67.9 & 84.0 & 114.3 & 149.1 & 182.5 & 195.6 & 260.2 \\
\hline Grants & 33.3 & 45.3 & 58.8 & 88.9 & 95.5 & 91.7 & 124.9 \\
\hline Project grants & 28.0 & 35.4 & 51.2 & 81.6 & 87.7 & 84.1 & 117.4 \\
\hline Technical assistance grants & 5.3 & 9.9 & 7.7 & 7.4 & 7.8 & 7.6 & 7.5 \\
\hline Direct foreign loans (project loans) & 26.7 & 27.1 & 46.4 & 43.3 & 47.3 & 56.3 & 67.9 \\
\hline Of which: technical assistance & 2.0 & 2.7 & 6.9 & 8.1 & 8.6 & 8.4 & 8.3 \\
\hline Budget & 7.0 & 9.7 & 9.1 & 16.9 & 39.7 & 47.6 & 67.3 \\
\hline Foreign on-lent loans & 0.9 & 1.9 & 0.0 & 0.0 & 0.0 & 0.0 & 0.0 \\
\hline Public enterprises & 4.4 & 7.9 & 1.4 & 1.9 & 1.6 & 1.5 & 1.5 \\
\hline Government-guaranteed foreign loans & 1.5 & 0.0 & 0.0 & 0.0 & 0.0 & 0.0 & 0.0 \\
\hline Self-financing and domestic loans & 2.8 & 7.9 & 1.4 & 1.9 & 1.6 & 1.5 & 1.5 \\
\hline Public sector & 72.2 & 91.9 & 115.6 & 151.0 & 184.1 & 197.2 & 261.7 \\
\hline Grants & 33.3 & 45.3 & 58.8 & 88.9 & 95.5 & 91.7 & 124.9 \\
\hline Foreign loans & 29.1 & 29.0 & 46.4 & 43.3 & 47.3 & 56.3 & 67.9 \\
\hline \multicolumn{8}{|l|}{ Budget, self-financing } \\
\hline and domestic loans & 9.8 & 17.6 & 10.5 & 18.8 & 41.3 & 49.1 & 68.8 \\
\hline
\end{tabular}


Table 19. Burkina Faso: Personnel Expenditures, 1993-1999

\begin{tabular}{|c|c|c|c|c|c|c|c|}
\hline & 1993 & 1994 & 1995 & 1996 & 1997 & 1998 & 1999 \\
\hline Number of civil servants & 35,661 & 37,052 & 41,240 & 43,849 & 43,903 & 45,477 & 46,622 \\
\hline Including agents of decentralised administrative entities & $\ldots$ & $\ldots$ & 42,917 & 45,684 & 45,638 & 49,088 & 50,233 \\
\hline \multicolumn{8}{|l|}{ Total wage bill (in billions of CFA francs) $1 /$} \\
\hline Budget & 52.2 & 58.1 & 61.6 & 63.2 & 65.1 & 71.7 & 79.5 \\
\hline Actual & 52.2 & 58.2 & 61.6 & 64.7 & 67.7 & 72.0 & 82.6 \\
\hline Implementation ratio (in percent) & 100.1 & 100.3 & 100.0 & 102.4 & 104.0 & 100.4 & 103.9 \\
\hline Civilian & 38.9 & 44.9 & 46.7 & 46.7 & 46.7 & 54.8 & 64.5 \\
\hline Military & 13.3 & 13.3 & 14.9 & 14.9 & 16.3 & 17.2 & 18.1 \\
\hline \multicolumn{8}{|l|}{ Memorandum items: } \\
\hline \multicolumn{8}{|l|}{ Average annual civilian wage bill } \\
\hline In millions of CFA francs & 1.1 & 1.2 & 1.2 & 1.5 & 1.5 & 1.6 & 1.8 \\
\hline Ratio of per capita civilian wage bill to per capita GDP & 14.1 & 12.4 & 10.3 & 12.1 & 12.2 & 11.8 & 13.0 \\
\hline
\end{tabular}

Source: Burkinabè authorities. 
Table 20. Burkina Faso: Military Expenditures, 1993-1999 1/

(In billions of CFA francs, unless otherwise indicated)

\begin{tabular}{|c|c|c|c|c|c|c|c|}
\hline & 1993 & 1994 & 1995 & 1996 & 1997 & 1998 & 1999 \\
\hline Salaries & 13.3 & 13.3 & 14.9 & 14.9 & 16.3 & 17.1 & 18.0 \\
\hline Percent change & 0.1 & -0.2 & 11.8 & 0.2 & 9.4 & 4.9 & 5.3 \\
\hline Goods and services & 3.7 & 3.2 & 3.4 & 3.5 & 3.7 & 3.9 & 4.4 \\
\hline Percent change & 37.3 & -12.1 & 4.5 & 3.6 & 5.7 & 5.4 & 11.7 \\
\hline Current transfers & 0.1 & 0.1 & 0.0 & 0.3 & 0.3 & 0.3 & 0.4 \\
\hline Investments & 0.1 & 0.2 & 0.2 & 0.3 & 2.2 & 1.9 & 2.9 \\
\hline Percent change & 161.5 & 28.7 & 8.0 & 58.7 & 633.3 & -13.6 & 52.6 \\
\hline Total & 17.2 & 16.8 & 18.4 & 19.0 & 22.5 & 23.2 & 25.7 \\
\hline Percent change & 7.2 & -2.4 & 9.9 & 3.0 & 18.4 & 2.6 & 10.6 \\
\hline
\end{tabular}

Source: Burkinabè authorities.

1/ Budgetary data only. 
Table 21. Burkina Faso: Total Revenue, 1993-99 1/

\begin{tabular}{|c|c|c|c|c|c|c|c|}
\hline & 1993 & 1994 & 1995 & 1996 & 1997 & 1998 & 1999 \\
\hline & \multicolumn{7}{|c|}{ (In millions of CFA francs) } \\
\hline Total revenue & 100,000 & 113,310 & 136,656 & 160,064 & 181,442 & 199,352 & 238,125 \\
\hline Tax revenue & 71,900 & 101,984 & 127,261 & 148,979 & 166,380 & 183,527 & 222,231 \\
\hline Lrscorne taxes & 15,438 & 21,208 & 30,179 & 39,493 & 39,821 & 43,532 & 53,740 \\
\hline Corporate incone tax & 5,502 & 6,664 & 15,988 & 19,458 & 19,555 & 18,891 & 24,879 \\
\hline Personal incorne tax & 8,198 & 10,755 & 12,365 & 16,134 & 16,459 & 19,735 & 22,404 \\
\hline Other & 1,738 & 3,789 & 1,827 & 3,901 & 3,808 & 4,906 & 6,457 \\
\hline Payroll taxes & 1,069 & 1,125 & 1,230 & 2,068 & 2,068 & 2,234 & 2,429 \\
\hline Property taxes & 509 & 784 & 673 & 543 & 710 & 1,080 & 893 \\
\hline Taxes on goods and services $1 /$ & 27,859 & 45,664 & 53,446 & 59,822 & 72,322 & 81,958 & 102,980 \\
\hline Tumover tax & 2,322 & 383 & 82 & 35 & 0 & 0 & 0 \\
\hline Value-added tax & 19,157 & 30,136 & 34,963 & 39,622 & 50,497 & 58,850 & 63,675 \\
\hline Value-added tax (import) & 7,261 & 11,676 & 13,481 & 19,498 & 25,564 & 31,464 & 30,735 \\
\hline Value-added tax (domestic) & $\pi 1,896$ & 18,460 & 21,482 & 20,124 & 24,933 & 27,386 & 32,940 \\
\hline Selected excises on goods & 2,910 & 12,096 & 12,659 & 13,778 & 14,527 & 13,824 & 17,629 \\
\hline Of which: Single tax on petroleum products & $\ldots$ & 8,647 & 8,927 & 8,789 & 9,367 & 8,229 & 11,652 \\
\hline Other $1 /$ & 3,470 & 3,432 & 5,824 & 6,422 & 7,298 & 9,284 & 21,676 \\
\hline Taxes on international trade $1 / 2 /$ & 24,194 & 32,664 & 40,693 & 45,182 & 49,971 & 52,195 & 60,228 \\
\hline Import duties & 22,702 & 30,844 & 36,384 & 40,048 & 43,075 & 43,882 & 40,445 \\
\hline Custoras duty & 11,700 & 23,840 & 28,324 & 30,878 & 32,631 & 32,235 & 29,040 \\
\hline Statistical tax & $\cdots$ & 6,768 & 8,060 & 9,168 & 10,442 & 11,647 & 11,405 \\
\hline Special intervention tax & $\ldots$ & 647 & 3,522 & 4,695 & 4,911 & 2,942 & $\ldots$ \\
\hline Other taxes on international trade $1 / 2 /$ & 1,492 & 1,172 & 787 & 439 & 1,985 & 5,371 & 19,782 \\
\hline Other tax revenue & 4,409 & 2,448 & 2,943 & 4,482 & 4,266 & 5,842 & 5,284 \\
\hline Nontax Revenue & 26,700 & 11,320 & 9,383 & 11,039 & 14,924 & 15,643 & 15,836 \\
\hline Dividends & 2,820 & 1,342 & 3,798 & 4,280 & 6,748 & 6,138 & 5,860 \\
\hline Other & 23,880 & 9,978 & 7,584 & 6,759 & 8,176 & 9,505 & 9,976 \\
\hline \multirow[t]{2}{*}{ Capital revenue } & 1400 & 6 & 13 & 46 & 139 & 182 & 57.8 \\
\hline & \multicolumn{7}{|c|}{ (In percent of GDP) } \\
\hline Total revenue & 12.6 & 11.0 & 11.6 & 12.3 & 13.0 & 13.1 & 15.0 \\
\hline Tax revenue & 9.0 & 9.9 & 10.8 & 11.5 & 11.9 & 12.1 & 14.0 \\
\hline Incorne taxes & 1.9 & 2.1 & 2.6 & 30 & 2.8 & 2.9 & 3.4 \\
\hline Of which: corporate income tax & 0.7 & 0.6 & 1.4 & 1.5 & 1.4 & 1.2 & 1.6 \\
\hline personal income tax & 1.0 & 1.0 & 3.1 & 12 & 1.2 & 1.3 & 1.4 \\
\hline Tax on manpower & 0.2 & 0.4 & 0.2 & 0.3 & 0.3 & 0.3 & 0.4 \\
\hline Property taxes & 0.1 & 0.1 & 0.1 & 0.2 & 0.1 & 0.1 & 0.2 \\
\hline Taxes on goods and services & 3.5 & 4.4 & 4.5 & 4.6 & 5.2 & 5.4 & 6.5 \\
\hline Of which: value-added tax & $\ldots$ & 2.9 & 3.0 & 3.1 & 3.6 & 3.9 & 4.0 \\
\hline Taxes on international trade & 3.0 & 3.2 & 3.5 & 3.5 & 3.6 & 3.4 & 3.8 \\
\hline Of which: taxes on imports & 2.9 & 3.0 & 3.1 & 3.1 & 3.1 & 2.9 & 2.5 \\
\hline Other tax receipts & 0.6 & 0.2 & 0.3 & 0.3 & 0.3 & 0.4 & 0.3 \\
\hline \multirow[t]{2}{*}{ Nontax revenue } & 3.4 & 1.1 & 0.8 & 0.9 & 1.1 & 1.0 & 1.0 \\
\hline & \multicolumn{7}{|c|}{ (In percent of total revenue, usless otherwise indicated) } \\
\hline Total revenue & 100.0 & 100.0 & 86.0 & 88.0 & 92.0 & 99.0 & 100.0 \\
\hline Tax revernue & 71.9 & 90.5 & 93.1 & 93.1 & 91.7 & 92.1 & 93.3 \\
\hline Income taxes & 18.9 & 17.7 & 22.1 & 24.7 & 21.9 & 21.8 & 22.6 \\
\hline Of which : corporate income tax & 7.8 & 5.6 & 11.7 & 12.2 & 10.8 & 9.5 & 10.4 \\
\hline personal income tax & 9.1 & 9.0 & 9.0 & 10.1 & 9.1 & 9.9 & 9.4 \\
\hline Payroll taxes & 1.1 & 0.9 & 0.9 & 1.3 & 1.1 & 1.1 & 1.0 \\
\hline Property taxes & 0.5 & 0.7 & 0.5 & 0.3 & 0.4 & 0.5 & 0.4 \\
\hline Taxes on goods and services & 14.1 & 43.5 & 39.1 & 37.4 & 39.9 & 41.1 & 43.2 \\
\hline Of which: Value-added tax & 9.4 & 30.8 & 25.6 & 24.8 & 27.8 & 29.5 & 26.7 \\
\hline Taxes on international trade & $\ldots$ & 15.4 & 29.8 & 28.2 & 27.5 & 26.2 & 25.3 \\
\hline Of which : axes on imports & 0.0 & 7.2 & 26.6 & 25.0 & 23.7 & 22.0 & 17.0 \\
\hline Other tax receipts & 0.9 & 0.5 & 2.2 & 2.8 & 2.4 & 2.9 & 2.2 \\
\hline Nontax revenue & 26.7 & 9.5 & 6.9 & 6.9 & 8.2 & 7.8 & 6.7 \\
\hline Of which : dividends & 2.8 & 1.1 & 1.3 & 2.7 & 3.7 & 3.1 & 2.5 \\
\hline GDP (in billions of CFA francs) & 796 & 1,029 & 1,176 & 1,298 & 1,398 & 1,522 & 1,589 \\
\hline
\end{tabular}

Source: Burkinabè authorities.

1/ Starting in 5999, revenue includes taxes on goods and services paid in execution of public investrnent projects using checks issued by the treasury.

2/ including the community solidarity levies of the WAEMU and ECOWAS. 
Table 22. Burkina Faso: Monetary Survey, 1995-1999

\begin{tabular}{|c|c|c|c|c|c|}
\hline & 1995 & 1996 & 1997 & 1998 & 1999 \\
\hline & \multicolumn{5}{|c|}{ (In billions of CFA francs; end of period) } \\
\hline Net foreign assets $1 /$ & 234.1 & 226.2 & 203.1 & 185.0 & 177.9 \\
\hline BCEAO & 129.5 & 131.6 & 133.3 & 120.8 & 100.7 \\
\hline Commercial banks & 104.6 & 94.6 & 69.8 & 64.2 & 77.2 \\
\hline Net domestic assets & 82.0 & 107.5 & 177.1 & 204.3 & 238.4 \\
\hline Domestic credit & 77.1 & 121.4 & 204.7 & 217.3 & 238.2 \\
\hline Net claims on government $2 /$ & -5.3 & 6.2 & 35.5 & 37.1 & 50.2 \\
\hline Credit to private sector & 82.4 & 115.2 & 169.1 & 180.2 & 188.0 \\
\hline Credit to other financial instintions & 1.9 & 0.4 & 0.7 & 1.1 & 1.1 \\
\hline Performing credit & 75.4 & 111.8 & 164.4 & 171.7 & 179.7 \\
\hline Short term & 55.2 & 85.6 & 127.5 & 125.0 & 137.7 \\
\hline Of which : crop credit & 0.5 & 3.4 & 17.6 & 21.0 & 15.0 \\
\hline Medium and long term & 20.2 & 26.2 & 36.8 & 46.8 & 42.0 \\
\hline Nonperforming credit & 5.2 & 3.0 & 4.1 & 7.4 & 7.2 \\
\hline Other items (net) & 4.9 & -13.9 & -27.6 & -13.1 & 0.2 \\
\hline Money and quasi money & 299.7 & 324.4 & 370.6 & 376.9 & 401.4 \\
\hline Currency & 123.5 & 138.2 & 169.3 & 165.0 & 151.3 \\
\hline Demand deposits & 90.2 & 91.7 & 98.7 & 96.9 & 115.8 \\
\hline Time and savings deposits & 86.0 & 94.4 & 102.7 & 115.0 & 134.3 \\
\hline Long-term foreign liabilities & 9.1 & 2.2 & 2.1 & 4.7 & 7.1 \\
\hline \multirow[t]{2}{*}{ SDR allocations } & 7.3 & 7.0 & 7.5 & 7.6 & 7.9 \\
\hline & \multicolumn{5}{|c|}{ (In percent of beginning-of-period broad money, unless otherwise indicated) } \\
\hline \multicolumn{6}{|l|}{ Memorandum items: } \\
\hline Net foreign assets & 29.9 & -2.6 & -7.1 & -4.9 & -1.9 \\
\hline Net domestic assets & -6.3 & 8.5 & 21.4 & 7.3 & 9.1 \\
\hline Of which: net claims on government & -6.2 & 3.8 & 9.0 & 0.4 & 3.5 \\
\hline credit to private sector & 3.4 & 11.0 & 16.6 & 3.0 & 2.1 \\
\hline Money and quasi money & 23.7 & 8.2 & 14.2 & 1.7 & 6.5 \\
\hline Nonperforning credit/total credit (percent) & 6.3 & 2.6 & 2.4 & 4.1 & 3.8 \\
\hline
\end{tabular}

Source: Central Bank of West African States (BCEAO).

1/ Excluding net external position of the postal checking system; excluding gold.

2/ Definition of govenment comprises central government as well as CGP, CSPPA, and OFNACER. 
Table 23. Burkina Faso: Summary Accounts of the Central Bank, 1995-99

(In billions of CFA francs; end of period)

\begin{tabular}{|c|c|c|c|c|c|}
\hline & 1995 & 1996 & 1997 & 1998 & 1999 \\
\hline Net foreign assets $1 /$ & 129.5 & 131.6 & 133.3 & 120.8 & 100.8 \\
\hline Assets & 170.9 & 177.3 & 206.4 & 210.1 & 195.2 \\
\hline Liabilities & 41.4 & 45.7 & 73.1 & 89.3 & 94.4 \\
\hline Net claims on government & 15.0 & 21.4 & 49.7 & 44.5 & 58.8 \\
\hline Claims & 55.7 & 59.3 & 80.1 & 92.9 & 103.7 \\
\hline Liabilities & 40.7 & 37.8 & 30.4 & 48.4 & 44.9 \\
\hline Net claims on banks & -17.3 & -7.5 & -2.3 & 8.6 & -9.7 \\
\hline Claims & 2.5 & 4.0 & 14.6 & 24.7 & 3.9 \\
\hline Rediscounts & 2.5 & 4.0 & 14.6 & 24.7 & 3.9 \\
\hline Liabilities & 19.8 & 11.4 & 16.9 & 16.1 & 13.6 \\
\hline Deposits on money market & 6.0 & 0.0 & 0.0 & 0.0 & 0.0 \\
\hline Other deposits & 11.1 & 7.2 & 11.4 & 11.0 & 7.7 \\
\hline Currency & 2.8 & 4.2 & 5.5 & 5.1 & 5.9 \\
\hline Net claims on other financial institutions & 0.2 & 0.4 & 0.7 & 1.1 & 1.1 \\
\hline Currency outside banks & 123.5 & 138.2 & 169.3 & 165.0 & 151.3 \\
\hline Public enterprise deposits & 6.0 & 6.1 & 6.0 & 5.2 & 5.2 \\
\hline SDR allocations & 7.3 & 7.0 & 7.5 & 7.6 & 7.9 \\
\hline Other items (net) & -9.3 & -5.5 & -1.3 & -2.9 & -13.4 \\
\hline
\end{tabular}

Source: Central Bank of West African States (BCEAO).

1/ Excluding gold. 
Table 24. Burkina Faso: Summary Accounts of Deposit Money Banks, 1995-99 1/

(In billions of CFA francs; end of period)

\begin{tabular}{|c|c|c|c|c|c|}
\hline & 1995 & 1996 & 1997 & 1998 & 1999 \\
\hline Net foreign assets & 104.6 & 94.6 & 69.8 & 64.2 & 77.2 \\
\hline Assets & 124.2 & 119.2 & 100.3 & 97.2 & 153.7 \\
\hline Liabilities & 19.7 & 24.6 & 30.5 & 33.0 & 76.5 \\
\hline Net money market position & 6.0 & 0.0 & 1.0 & 0.0 & 0.0 \\
\hline Deposits & 6.0 & 0.0 & 1.0 & 0.0 & 0.0 \\
\hline Advances & 0.0 & 0.0 & 0.0 & 0.0 & 0.0 \\
\hline Other reserves & 11.7 & 11.2 & 14.7 & 16.5 & 15.8 \\
\hline Currency & 2.8 & 4.2 & 5.5 & 5.1 & 5.9 \\
\hline Deposits at BCEAO & 8.9 & 7.0 & 9.1 & 11.4 & 9.9 \\
\hline Net claims on government & -20.3 & -15.2 & -16.1 & -12.2 & -8.1 \\
\hline Claims & 42.5 & 41.2 & 43.3 & 47.0 & 50.7 \\
\hline Deposits & 62.8 & 56.5 & 59.4 & 59.2 & 58.8 \\
\hline Claims on economy $2 /$ & 80.5 & 114.8 & 168.4 & 179.2 & 186.9 \\
\hline Performing credits & 75.4 & 111.8 & 164.4 & 171.7 & 179.7 \\
\hline Short term & 55.2 & 85.6 & 127.5 & 125.0 & 137.7 \\
\hline Of which : crop credit & 0.5 & 3.4 & 17.6 & 21.0 & 15.0 \\
\hline Medium and long term & 20.2 & 26.2 & 36.8 & 46.8 & 42.0 \\
\hline Nonperforming credit & 5.2 & 3.0 & 4.1 & 7.4 & 7.2 \\
\hline Unpaid claims & 0.5 & 0.5 & 0.9 & 2.4 & 2.3 \\
\hline Doubtful and litigious credit & 4.6 & 2.5 & 3.1 & 5.0 & 4.9 \\
\hline Claims on other financial institutions & 1.6 & 0.0 & 0.0 & 0.0 & 0.0 \\
\hline Deposits & 170.3 & 180.0 & 195.3 & 206.7 & 244.7 \\
\hline Demand deposits & 84.2 & 85.6 & 92.6 & 91.7 & 110.5 \\
\hline Public enterprises & 16.0 & 15.9 & 12.3 & $\ldots$ & $\ldots$ \\
\hline Other & 68.2 & 69.7 & 80.3 & $\ldots$ & $\ldots$ \\
\hline Time deposits & 86.0 & 94.4 & 102.7 & 115.0 & 134.3 \\
\hline Public enterprises & 19.1 & 23.8 & 19.6 & $\ldots$ & $\ldots$ \\
\hline Other & 66.9 & 70.7 & 83.1 & $\cdots$ & $\ldots$ \\
\hline BCEAO claims & 2.5 & 4.0 & 14.6 & 24.7 & 3.9 \\
\hline Long-term foreign liabilities & 9.1 & 2.2 & 2.1 & 4.7 & 7.1 \\
\hline Other items (net) & 2.2 & 19.2 & 25.7 & 11.6 & 16.1 \\
\hline
\end{tabular}

Source: Central Bank of West African States (BCEAO).

1/ Including treasury operations with private sector, Postal Checking (CCP), and National Savings Banks (CNE).

2/ Including public corporations. 
Table 25. Burkina Faso: Central Bank Interest Rates, January 1996-December 1999

(In percent per year; end of period)

\begin{tabular}{|c|c|c|c|c|}
\hline & $\begin{array}{r}\text { Rediscount } \\
\text { Rate } \\
\end{array}$ & $\begin{array}{r}\text { Repurchase } \\
\text { Rate } \\
\end{array}$ & $\begin{array}{r}\text { Rate on Treasury } \\
\text { Advances } \\
\end{array}$ & $\begin{array}{l}\text { Penalty } \\
\text { Rate } 1 / \\
\end{array}$ \\
\hline \multicolumn{5}{|l|}{1996} \\
\hline January & 7.50 & 6.50 & 4.51 & 7.00 \\
\hline February & 7.50 & 6.50 & 4.51 & 7.00 \\
\hline March & 7.50 & 6.50 & 4.51 & 7.00 \\
\hline April & 7.50 & 6.50 & 4.37 & 7.00 \\
\hline May & 7.50 & 6.50 & 4,37 & 7.00 \\
\hline June & 7.50 & 6.50 & 4.37 & 7.00 \\
\hline July & 7.50 & 6.50 & 5.31 & 7.00 \\
\hline August & 7.00 & 6.00 & 5.31 & 6.50 \\
\hline September & 7.00 & 6.00 & 5.31 & 6.50 \\
\hline October & 6.50 & 6.00 & 5.17 & 6.50 \\
\hline November & 6.50 & 6.00 & 5.17 & 6.50 \\
\hline December & 6.50 & 6.00 & 5.17 & 6.50 \\
\hline \multicolumn{5}{|l|}{1997} \\
\hline January & 6.50 & 6.00 & 5.05 & 6.50 \\
\hline February & 6.25 & 5.75 & 5.05 & 6.25 \\
\hline March & 6.25 & 5.75 & 5.05 & 6.25 \\
\hline April & 6.25 & 5.75 & 5.01 & 6.25 \\
\hline May & 6.25 & 5.75 & 5.01 & 6.25 \\
\hline June & 6.25 & 5.75 & 5.01 & 6.25 \\
\hline July & 6.25 & 5.75 & 5.02 & 6.25 \\
\hline August & 6.25 & 5.75 & 5.02 & 6.25 \\
\hline September & 6.25 & 5.50 & 5.02 & 6.00 \\
\hline October & 6.25 & 5.50 & 5.03 & 6.00 \\
\hline November & 6.25 & 5.50 & 5.03 & 6.00 \\
\hline December & 6.00 & 5.50 & 5.03 & 6.00 \\
\hline \multicolumn{5}{|l|}{1998} \\
\hline January & 6.00 & 5.50 & 4.51 & 6.00 \\
\hline February & 6.00 & 5.50 & 4.51 & 6.00 \\
\hline March & 6.00 & 5.50 & 4.51 & 6.00 \\
\hline April & 6.00 & 5.50 & 4.75 & 6.00 \\
\hline May & 6.00 & 5.50 & 4.75 & 6.00 \\
\hline June & 6.00 & 5.50 & 4.75 & 6.00 \\
\hline July & 6.00 & 5.50 & 4.95 & 6.00 \\
\hline August & 6.25 & 5.75 & 4.95 & 6.25 \\
\hline September & 6.25 & 5.75 & 4.95 & 6.25 \\
\hline October & 6.25 & 5.75 & 4.95 & 6.25 \\
\hline November & 6.25 & 5.75 & 4.95 & 6.25 \\
\hline December & 6.25 & 5.75 & 4.95 & 6.25 \\
\hline \multicolumn{5}{|l|}{1999} \\
\hline January & 5.75 & 5.25 & 4.95 & 5.75 \\
\hline February & 5.75 & 5.25 & 4.95 & 5.75 \\
\hline March & 5.75 & 5.25 & 4.95 & 5.75 \\
\hline April & 5.75 & 5.25 & 4.95 & 5.75 \\
\hline May & 5.75 & 5.25 & 4.95 & 5.75 \\
\hline June & 5.75 & 5.25 & 4.95 & 5.75 \\
\hline July & 5.75 & 5.25 & 4.95 & 5.75 \\
\hline August & 5.75 & 5.25 & 4.95 & 5.75 \\
\hline September & 5.75 & 5.25 & 4.95 & 5.75 \\
\hline October & 5.75 & 5.25 & 4.95 & 5.75 \\
\hline November & 5.75 & 5.25 & 4.95 & 5.75 \\
\hline December & 5.75 & 5.25 & 4.95 & 5.75 \\
\hline
\end{tabular}

Source: Central Bank of West African States (BCEAO).

1/ The penalty rate applies to central bank credit to the government in excess of statutory limits and is equivalent to the repurchase rate plus 0.5 percentage point. 
Table 26. Burkino Faso: Money Market Interest Rates, January 1996-December 1999

(In percent per year)

\begin{tabular}{|c|c|c|c|}
\hline & \multicolumn{3}{|c|}{ Monthly Average Rate 1/ } \\
\hline & $\begin{array}{l}\text { Advances } \\
\text { and deposits } \\
\text { (TMM) }\end{array}$ & $\begin{array}{l}\text { BCEAO } \\
\text { bonds } 2 /\end{array}$ & Interbank rate \\
\hline \multicolumn{4}{|l|}{1996} \\
\hline January & 5.52 & $\ldots$ & $\ldots$ \\
\hline February & 5.50 & $\ldots$ & $\cdots$ \\
\hline March & 5.50 & $\ldots$ & $\begin{array}{l}\cdots \\
\ldots\end{array}$ \\
\hline April & 5.48 & $\ldots$ & $\cdots$ \\
\hline May & 5.22 & $\cdots$ & $\cdots$ \\
\hline June & 5.37 & $\cdots$ & $\cdots$ \\
\hline July & 5.42 & $\begin{array}{l}\cdots \\
\ldots\end{array}$ & $\cdots$ \\
\hline August & 5.25 & $\ldots$ & $\ldots$ \\
\hline September & 5.25 & 4.00 & $4.00-6.25$ \\
\hline October & 5.25 & 4.13 & $\begin{array}{l}4.00-6.25 \\
4.00-6.25\end{array}$ \\
\hline November & 5.20 & $\ldots$ & $4,00-6.25$ \\
\hline December & 5.06 & $\cdots$ & $4.00-6.25$ \\
\hline & & $\cdots$ & $4.00-6.25$ \\
\hline \multicolumn{4}{|l|}{1997} \\
\hline January & 5.04 & $\ldots$ & $4.00-6.25$ \\
\hline February & 5.12 & $\ldots$ & $4.00-6.25$ \\
\hline March & 5.00 & $\ldots$ & $4.00-6.25$ \\
\hline April & 5.00 & $\ldots$ & $4.00-6.25$ \\
\hline May & 5.00 & $\ldots$ & $4.00-6.25$ \\
\hline June & 5.02 & 4.65 & $\ldots$ \\
\hline July & 5.02 & 5.00 & $\cdots$ \\
\hline August & 5.02 & 4.00 & $\cdots$ \\
\hline September & 5.02 & 3.80 & $\cdots$ \\
\hline October & 5.02 & 3.80 & $\cdots$ \\
\hline November & 5.02 & 4.00 & $\ldots$ \\
\hline December & 4.96 & $\ldots$ & $\cdots$ \\
\hline \multicolumn{4}{|l|}{1998} \\
\hline January & 4.51 & $\ldots$ & $\ldots$ \\
\hline February & 4.50 & $\ldots$ & $\ldots$ \\
\hline March & 4.53 & $\ldots$ & ".. \\
\hline April & 4.56 & $\cdots$ & $\cdots$ \\
\hline May & 4.78 & $\ldots$ & $\cdots$ \\
\hline June & 4.95 & 4.50 & $\cdots$ \\
\hline July & 4.95 & 4.50 & $\cdots$ \\
\hline August & 4.95 & 4.50 & $\cdots$ \\
\hline September & 4.95 & 4.75 & $\cdots$ \\
\hline October & 4.95 & 4.75 & $\cdots$ \\
\hline November & 4.95 & 4.75 & $\cdots$ \\
\hline December & 4.95 & & $\ldots$ \\
\hline & 4.95 & $\cdots$ & $\cdots$ \\
\hline \multicolumn{4}{|l|}{1999} \\
\hline January & 4.95 & $\ldots$ & $\ldots$ \\
\hline February & 4.95 & $\begin{array}{l}\cdots \\
\cdots\end{array}$ & $\cdots$ \\
\hline March & 4.95 & $\begin{array}{l}\cdots \\
\cdots\end{array}$ & $\cdots$ \\
\hline April & 4.95 & $\cdots$ & $\begin{array}{l}\cdots \\
\ldots\end{array}$ \\
\hline May & 4.95 & $\ldots$ & $\cdots$ \\
\hline June & 4.95 & $\begin{array}{l}\cdots \\
\cdots\end{array}$ & $\cdots$ \\
\hline July & 4.95 & $\ldots$ & $\cdots$ \\
\hline August & 4.95 & 3.75 & $\begin{array}{l}\cdots \\
\cdots\end{array}$ \\
\hline September & 4.95 & 4.00 & $\ldots$ \\
\hline October & 4.95 & $\ldots$ & $\ldots$ \\
\hline November & 4.95 & $\ldots$ & $\begin{array}{l}\cdots \\
\ldots\end{array}$ \\
\hline December & 4.95 & $\cdots$ & $\begin{array}{l}\cdots \\
\cdots\end{array}$ \\
\hline
\end{tabular}

Source: Central Bank of West African States (BCEAO).

1/ The money market was introduced in 1975 and has functioned with an auction system since October 1993. Under this system, only part of the funds offered by commercial banks are accepted by the central bank the interest rate can be either fixed by the central bank or determined as a result of the auction.

2/ Bonds issued by the BCEAO to absoro excess liquidity were first issued in August 1996; emission was suspended between November 1996 and May 1997. 
Table 27. Burkina Faso: Maximum Lending Rates Applied by Commercial Banks, October 1993-December 1999 1/

(In percent per year)

\begin{tabular}{|c|c|c|c|c|c|c|c|c|c|c|c|c|c|c|}
\hline & $\begin{array}{l}\text { From } \\
\text { Oct. 1, } \\
1993 \\
\end{array}$ & $\begin{array}{c}\text { From } \\
\text { Dec. 20, } \\
1993 \\
\end{array}$ & $\begin{array}{c}\text { From } \\
\text { Jan. 18, } \\
1994 \\
\end{array}$ & $\begin{array}{l}\text { From } \\
\text { June 27, } \\
1994 \\
\end{array}$ & $\begin{array}{l}\text { From } \\
\text { Aug. 1, } \\
1994 \\
\end{array}$ & $\begin{array}{r}\text { From } \\
\text { Aug. 29, } \\
\text { 1994 } \\
\end{array}$ & $\begin{array}{c}\text { From } \\
\text { Jan. } 23, \\
1995 \\
\end{array}$ & $\begin{array}{c}\text { From } \\
\text { June } 5 \text {, } \\
1995 \\
\end{array}$ & $\begin{array}{r}\text { From } \\
\text { Dec. 26, } \\
1995 \\
\end{array}$ & $\begin{array}{c}\text { From } \\
\text { Aug. 5, } \\
1996 \\
\end{array}$ & $\begin{array}{r}\text { From } \\
\text { Aug. 19, } \\
1996 \\
\end{array}$ & $\begin{array}{c}\text { From } \\
\text { Oct. 21, } \\
1996 \\
\end{array}$ & $\begin{array}{r}\text { From } \\
\text { Feb. 17, } \\
1997 \\
\end{array}$ & $\begin{array}{r}\text { July } 30,1997 \text { to } \\
\text { Dec. } 31,1999 \\
\end{array}$ \\
\hline \multicolumn{15}{|l|}{ Short- and medium-term credit } \\
\hline $\begin{array}{l}\text { Crop financing and export credit } \\
\text { Financing of storage of }\end{array}$ & 25.0 & 21.0 & 29.0 & 24.0 & 22.0 & 20.0 & 18.0 & 17.0 & 15.0 & 14.5 & 14.0 & 13.0 & 12.5 & 18.0 \\
\hline agricultural products & 25.0 & 21.0 & 29.0 & 24.0 & 22.0 & 20.0 & 18.0 & 17.0 & 15.0 & 14.5 & 14.0 & 13.0 & 12.5 & 18.0 \\
\hline $\begin{array}{l}\text { Credit to small and medium- } \\
\text { sized national enterprises }\end{array}$ & 25.0 & 21.0 & 29.0 & 24.0 & 22.0 & 20.0 & 18.0 & 17.0 & 15.0 & 14.5 & 14.0 & 13.0 & 12.5 & 18.0 \\
\hline \multicolumn{15}{|l|}{$\begin{array}{l}\text { Credit to nationals } 2 / \text { for } \\
\text { construction of first }\end{array}$} \\
\hline primary residence & 25.0 & 21.0 & 29.0 & 24.0 & 22.0 & 20.0 & 18.0 & 17.0 & 15.0 & 14.5 & 14.0 & 13.0 & 12.5 & 18.0 \\
\hline Other credits & 25.0 & 21.0 & 29.0 & 24.0 & 22.0 & 20.0 & 18.0 & 17.0 & 15.0 & 14.5 & 14.0 & 13.0 & 12.5 & 18.0 \\
\hline \multicolumn{15}{|l|}{ Long-term credit $3 /$} \\
\hline $\begin{array}{l}\text { Credit to small and medium- } \\
\text { sized national enterprises }\end{array}$ & 25.0 & 21.0 & 29.0 & 24.0 & 22.0 & 20.0 & 18.0 & 17.0 & 15.0 & 14.5 & 14.0 & 13.0 & 12.5 & 18.0 \\
\hline \multicolumn{15}{|l|}{$\begin{array}{l}\text { Credit to nationals } 2 / \text { for } \\
\text { construction of first }\end{array}$} \\
\hline primary residence & 25.0 & 21.0 & 29.0 & 24.0 & 22.0 & 20.0 & 18.0 & 17.0 & 15.0 & 14.5 & 14.0 & 13.0 & 12.5 & 18.0 \\
\hline Other credits & 25.0 & 21.0 & 29.0 & 24.0 & 22.0 & 20.0 & 18.0 & 17.0 & 15.0 & 14.5 & 14.0 & 13.0 & 12.5 & 18.0 \\
\hline
\end{tabular}

Source: Central Bank of West African States (BCEAO).

1/ All rate ceilings were unified in October 2, 1989 and set equal to the discount rate plus 5 percent. In October 1, 1993, maximum rates were revised to twice the level of the discount rate. In July 1997 , the usury rate was fixed at 18 percent.

2/ Of any member state of the West African Monetary Union.

$3 /$ With maturity of more than 2 years and less than 15 years. 
Table 28. Burkina Faso: Deposit Rates Applied by Commercial Banks, November 1989-December 1999 1/

(In percent per year)

\begin{tabular}{|c|c|c|c|c|c|c|c|c|}
\hline & $\begin{array}{r}\text { From } \\
\text { Nov. } 27, \\
1989 \\
\end{array}$ & $\begin{array}{r}\text { From } \\
\text { Aug. 20, } \\
1992 \\
\end{array}$ & $\begin{array}{r}\text { From } \\
\text { Nov, 9, } \\
1992 \\
\end{array}$ & $\begin{array}{l}\text { From } \\
\text { Oct. 1, } \\
1993\end{array}$ & $\begin{array}{r}\text { From } \\
\text { Jan. 19, } \\
1994 \\
\end{array}$ & $\begin{array}{c}\text { From } \\
\text { Jul. 8, } \\
1994 \\
\end{array}$ & $\begin{array}{r}\text { From } \\
\text { Sep. 26, } \\
1994 \\
\end{array}$ & $\begin{array}{r}\text { Apr. } 1,1996 \text { to } \\
\text { Dec. } 31,1999 \\
\end{array}$ \\
\hline & \multicolumn{8}{|c|}{ (Up to CFAF 500,000 ) } \\
\hline Public deposits $2 /$ & \multicolumn{8}{|c|}{ Determined by agreement } \\
\hline \multicolumn{9}{|l|}{$\begin{array}{l}\text { Private deposits } \\
\text { Time deposits }\end{array}$} \\
\hline ... 3/ TMM-2 4/ TMM-2 4/ TMM-2 4/ TMM-2 4/ & & $\ldots 3 /$ & $\ldots 3 /$ & TMM-2 4/ & TMM-2 4/ & TMM-2 4/ & TMM-2 4/ & TMM-2 4/ \\
\hline one year & ... $3 /$ & $\ldots 3 /$ & $\ldots 3 /$ & TMM-2 4/ & TMM-2 4/ & TMM-2 4/ & TMM-2 4/ & TMM-2 4/ \\
\hline One year or more & ... $3 /$ & ... 3/ & ... $3 /$ & $\ldots 3 /$ & $\ldots 3 /$ & $\ldots 3 /$ & $\ldots 37$ & ... $3 /$ \\
\hline \multicolumn{9}{|l|}{$\begin{array}{l}\text { Certificates of deposit } \\
\text { Six months to less than }\end{array}$} \\
\hline one year & $\ldots 3 /$ & ... $3 /$ & $\ldots 3 /$ & TMM-2 4/ & TMM-2 4/ & TMM-2 4/ & TMM-2 4/ & TMM-2 4/ \\
\hline One year or more & $\ldots 3 /$ & ... 31 & $\ldots 3 /$ & $\ldots 3 /$ & $\ldots 3 /$ & ... $3 /$ & ... 3/ & ... $3 /$ \\
\hline \multirow[t]{2}{*}{ Savings deposits $5 /$} & 7.0 & 9.0 & 8.5 & 4.5 & 8.0 & 5.0 & 4.5 & 3.5 \\
\hline & \multicolumn{8}{|c|}{ (Above CFAF 500,000 ) } \\
\hline Public deposits 2/ & \multicolumn{8}{|c|}{ Determined by agreement } \\
\hline \multicolumn{9}{|l|}{ Private deposits } \\
\hline \multicolumn{9}{|l|}{ Time deposits } \\
\hline $\begin{array}{l}\text { Less than six months } \\
\text { Six months to less than }\end{array}$ & $7.0^{*}$ & 9.0 & $8.5^{*}$ & $\ldots 3 /$ & $\ldots 3 /$ & $\ldots 3 /$ & $\ldots 31$ & $\ldots 3 /$ \\
\hline one year & $8.0^{*}$ & $10.0^{*}$ & $9.5^{*}$ & $\ldots 3 /$ & $\ldots 3 /$ & $\ldots 3 /$ & $\ldots 3 /$ & $\ldots 3 /$ \\
\hline One year or more & $9.0^{*}$ & $11.0^{*}$ & $10.5^{*}$ & $\ldots 3 /$ & $\ldots 3 /$ & $\ldots 3 /$ & $\ldots 3 /$ & $\ldots 3 /$ \\
\hline \multicolumn{9}{|l|}{$\begin{array}{l}\text { Certificates of deposit } \\
\text { Six months to less than }\end{array}$} \\
\hline one year & $8.0^{*}$ & $10.0^{*}$ & 9.5 & $\ldots 3 /$ & $\ldots 3 /$ & $\ldots 3 /$ & $\ldots 31$ & $\ldots 3 /$ \\
\hline One year and more & $9.0^{*}$ & $11.0^{*}$ & 10.5 & $\ldots 3 /$ & $\ldots 3 /$ & $\ldots 3 /$ & $\ldots 3 /$ & $\ldots 3$ \\
\hline Savings deposits & $7.0^{*}$ & $9.0^{*}$ & 8.5 & $\ldots 3 /$ & $\ldots 3 /$ & $\ldots 3 /$ & $\ldots 3 /$ & $\ldots 3 /$ \\
\hline
\end{tabular}

Source: Central Bank of West African States (BCEAO).

1/ Fixed rate, unless marked with an asterisk (*), in which case it is a minimum rate.

2/ Includes deposits of the Treasury, Post Office, Savings Bank, and other government agencies, public and mixed enterprises, and special private sector deposits resulting from legal requirements, such as reserves of insurance companies.

3/ Deposit rates no longer fixed by the Central Bank of West African States (BCEAO).

4/ Monthly average money market rate (TMM), published by the BCEAO, minus 2 percent.

$5 /$ Applicable to savings deposits of less than CFAF 5 million. 
Table 29. Burkina Faso: Balance of Payments, 1993-99

\begin{tabular}{|c|c|c|c|c|c|c|c|}
\hline & 1993 & 1994 & 1995 & 1996 & 1997 & 1998. & $\begin{array}{r}1999 \\
\text { Est. }\end{array}$ \\
\hline & \multicolumn{7}{|c|}{ (In billions of CFA francs) } \\
\hline Exports, f.o.b. & 74.5 & 104.4 & 118.2 & 119.0 & 133.7 & 190.4 & 156.6 \\
\hline Of which: cotton & 22.2 & 31.7 & 51.2 & 49.6 & 74.6 & 120.9 & 83.6 \\
\hline gold & 8.1 & 12.2 & 11.7 & 9.0 & 9.0 & 9.5 & 9.2 \\
\hline lmports, f.o.b. & -153.0 & -193.9 & .242 .2 & -288.0 & -297.7 & -374.2 & -368.7 \\
\hline Of which: capital goods & -32.2 & .44 .2 & -75.4 & -86.8 & -90.4 & -114.5 & -135.8 \\
\hline Trade balance & -78.6 & -89.6 & -124.1 & -168.9 & -164.0 & -183.8 & -212.0 \\
\hline Services and income (net) & -42.8 & -53.3 & -61.6 & -64.7 & -72.9 & -80.5 & -83.3 \\
\hline Services & -39.0 & -45.6 & -56.0 & -60.7 & -65.1 & $-73,5$ & -75.4 \\
\hline Income & -3.8 & -7.8 & -5.7 & -4.0 & -7.8 & -7.0 & -7.8 \\
\hline Of which: interest payruents & -8.3 & -12.5 & -10.6 & -10.7 & -11.3 & -10.2 & -11.4 \\
\hline Current transfers (net) & 74.8 & 124.0 & 119.3 & 104.9 & 95.6 & 111.5 & 95.0 \\
\hline Private & 43.9 & $\$ 3.6$ & 53.0 & 43.0 & 43.4 & 43.9 & 41.0 \\
\hline Of which : workers' remitsances (gross) & 33.2 & 54.6 & 55.1 & 56.4 & 51.1 & 54,4 & 51,0 \\
\hline Official & 30.9 & 70.4 & 66.3 & 61.9 & 52.2 & 67.6 & 54.0 \\
\hline Of which: budgetary & 15.2 & 40.0 & 36.8 & 27.3 & 16.8 & 19.6 & 23.7 \\
\hline Current account ( deficit=-) & -46.6 & -18.9 & -66.4 & -128.7 & -141.4 & -152.8 & -200.3 \\
\hline Excluding current official transfers & -77.5 & .89 .3 & -132.8 & -190.6 & -193.6 & -220.4 & -254.3 \\
\hline Capital transfers & 28.0 & 35.4 & 46.9 & 87.5 & 91.6 & 89.5 & 122.8 \\
\hline Project grants & 28,0 & 35.4 & 51.2 & 81.8 & 81.1 & 84.1 & $\$ 17.4$ \\
\hline Other capital transfers & 0.0 & 0.0 & -4.2 & 5.6 & 10.5 & 5.4 & 5.4 \\
\hline Official capital & 24.8 & 36.9 & 45.2 & 33.0 & 21.9 & 46.1 & 56.9 \\
\hline Disbursements & 36.9 & 57.8 & 69.6 & 52.5 & 47.3 & 69.6 & 84.0 \\
\hline Of which: budget & 35.3 & 57.8 & 69.6 & 47.7 & 47.3 & 69.6 & 84.0 \\
\hline Project loans & 27.6 & 29.0 & 46,4 & 43.3 & 47.3 & 56.3 & 67.9 \\
\hline $\begin{array}{l}\text { Program loans } \\
\text { P }\end{array}$ & 7.7 & 28.8 & 23.3 & 4.4 & 0.0 & 13.3 & 16.1 \\
\hline Amortization & -12.1 & -20.9 & -24.4 & $\cdot 19.5$ & -25.4 & -23.5 & -27.1 \\
\hline Of which: budget & -9.8 & .20 .9 & -24.4 & -17.0 & -21.9 & -20.0 & -26.3 \\
\hline Private capital U/ & 2.7 & 13.5 & 9.9 & 8.4 & 6.6 & -7.8 & 7.8 \\
\hline Errors and omissions & -2.4 & -6.2 & 32.5 & -2.0 & -1.7 & 2.6 & -0.7 \\
\hline Overail balance & 6.4 & 60.7 & 68.2 & -1.8 & -23.0 & -22.4 & -13.5 \\
\hline Financing & -6.4 & -60.7 & .68 .2 & 1.8 & 23.0 & 22.4 & 13.5 \\
\hline Net foreign assets & -17.3 & -51.0 & -71.4 & 0.7 & 20.2 & 19.6 & 9.4 \\
\hline Net official reserves & -15.6 & 7.3 & -38.8 & $\cdot 1.2$ & -2.9 & 12.9 & 20.0 \\
\hline Gross official reserves & -19.0 & -6.6 & .52 .3 & .5 .7 & -12.5 & 4.1 & 13.0 \\
\hline IMF (net) & 3.4 & 13.9 & 13.5 & 4.5 & 9.6 & 8.8 & 7.0 \\
\hline Of which: use of resources & 0.0 & 0.0 & 13.5 & 4.9 & 10.6 & 10.5 & 10.3 \\
\hline repayments & 0.0 & 0.0 & 0.0 & -0.5 & -1.0 & -1.7 & -3.3 \\
\hline Net foreign assets, commercial banks $2 /$ & -1.7 & -58.2 & -32.6 & 1.9 & 23.1 & 6.7 & -10.6 \\
\hline Of which: Post Office & -0.5 & 4.0 & 0.9 & 0.3 & 0.0 & 0.0 & 0.0 \\
\hline Change in atrears (reduction $=-$ ) & 7.6 & -17.3 & -1.4 & 0.0 & 0.0 & 0.0 & 0.0 \\
\hline Debt relief & 3.3 & 7.7 & 4.6 & 1.1 & 0.0 & 0.0 & 0.0 \\
\hline Debt under discussion $3 /$ & 0.0 & 0.0 & 0.0 & 0.0 & 2.8 & 2.8 & 4.2 \\
\hline
\end{tabular}

(In percent of GDP, unless otherwise indicated)

Memorandum items:

Trade balance ( deficit=-)

Current account ( deficit= -)

Excluding current officiaj transfers

Overall balance ( deficit $=$-)

Debt service

Debt-service ratio 4l

Gross international reserves (in billions of CFA francs)

In months of imported goods, c.i.f

Net official reserves (BCEAO)

GDP at current prices (in billions of CFA francs)

\begin{tabular}{rrrrrrr}
-9.9 & -8.7 & -10.6 & -13.0 & -11.8 & -12.1 & -13.3 \\
-5.9 & -1.8 & -5.7 & -9.9 & -10.2 & -10.0 & -12.6 \\
-9.7 & -8.7 & -11.3 & -14.7 & -13.9 & -14.5 & -16.0 \\
0.8 & 5.9 & 5.8 & -0.1 & -1.7 & -1.5 & 0.9 \\
2.6 & 3.2 & 3.0 & 2.4 & 2.7 & 2.3 & 2.6 \\
22.1 & 24.7 & 22.9 & 21.7 & 24.2 & 16.6 & 23.3 \\
128.3 & 210.0 & 295.1 & 296.5 & 306.7 & 307.3 & 300.8 \\
8.5 & 11.2 & 12.5 & 10.7 & 10.6 & 8.3 & 8.3 \\
98.0 & 90.7 & 129.5 & 131.6 & 134.4 & 121.5 & 101.5 \\
796.1 & $1,029.4$ & $1,175.5$ & $1,298.3$ & $1,390.1$ & $1,522.4$ & $1,588.6$ \\
\hline
\end{tabular}

Sources: Central Bank of West African States'(BCEAO); and staff estimates.

1/ Includes portfolio investment and direct foreign investment

$2 /$ Including net foreign assets of Post Office.

3/ Contentious debt in negotiation with non-Paris Club creditors.

4/ Including public enterprises and private sectot debt; in percent of exports of goods and nonfactor services. 
Table 30. Burkina Faso: Balance of Payments, 1993-99

(In millions of SDRs, unless otherwise indicated)

\begin{tabular}{|c|c|c|c|c|c|c|c|}
\hline & 1993 & 1994 & 1995 & 1996 & 1997 & 1998 & $\begin{array}{c}1999 \\
\text { Est. }\end{array}$ \\
\hline Exports, f.o.b. & 188.3 & 133.3 & 156.1 & 160.1 & 166.7 & 239.8 & 186.4 \\
\hline Of which : cotton & 56.1 & 40.5 & 67.6 & 66.7 & 93.1 & 152.2 & 99.5 \\
\hline Imports, f.o.b. & -387.1 & -247.7 & -319.9 & -387.4 & -371.2 & -471.2 & -438.7 \\
\hline Trade balance & -198.7 & -114.4 & -163.9 & -227.2 & -204.6 & -231.4 & -252.3 \\
\hline Services and income (net) & -108.4 & -68.1 & -81.4 & -87.0 & -90.9 & -101.3 & -99.1 \\
\hline Services & -98.7 & -58.2 & -73.9 & -81.6 & -81.2 & -92.5 & -89.8 \\
\hline Income & -9.7 & -9.9 & -7.5 & -5.4 & -9.7 & -8.8 & -9.3 \\
\hline Of which: interest payments & -21.0 & -16.0 & -13.9 & -14.4 & -14.1 & -12.8 & -13.6 \\
\hline Current transfers (net) & 189.2 & 158.4 & 157.5 & 141.2 & 119.2 & 140.3 & 113.0 \\
\hline Private & 111.0 & 68.4 & 70.0 & 57.9 & 54.1 & 55.2 & 48.8 \\
\hline Of which: workers' remittances & 84.0 & 69.8 & 72.7 & 75.9 & 63.7 & 68.5 & 60.7 \\
\hline Official & 78.3 & 89.9 & 87.6 & 83.3 & 65.1 & 85.1 & 64.2 \\
\hline Of which: budgetary & 38.6 & 51.0 & 48.6 & 36.7 & 20.9 & 24.7 & 28.2 \\
\hline Current account (deficit) & -117.9 & -24.2 & -87.7 & -173.1 & -176.3 & -192.4 & -238.4 \\
\hline Excluding official transfers & -196.1 & -114.1 & -175.3 & -256.4 & -241.4 & -277.5 & -302.6 \\
\hline Capital transfers & 70.8 & 45.2 & 62.0 & 117.6 & 114.2 & 112.7 & 146.1 \\
\hline Project grants & 70.8 & 45.2 & 67.6 & 110.1 & 101.1 & 105.9 & 139.8 \\
\hline Other capital transfers & 0.0 & 0.0 & -5.6 & 7.6 & 13.1 & 6.8 & 6.4 \\
\hline Official capital & 62.6 & 47.1 & 59.7 & 44.4 & 27.4 & 58.0 & 67.7 \\
\hline Disbursements & 93.2 & 73.9 & 92.0 & 70.7 & 59.0 & 87.6 & 99.9 \\
\hline Of which: budget & 89.3 & 73.9 & 92.0 & 64.2 & 59.0 & 87.6 & 99.9 \\
\hline Amortization & -30.6 & -26.7 & -32.2 & -26.2 & -31.7 & -29.6 & -34.1 \\
\hline Of which: budget & -24.7 & -26.7 & -32.2 & -22.9 & -27.3 & -25.2 & -33.1 \\
\hline Private capital 1/ & 6.8 & 17.3 & 13.1 & 11.2 & 8.2 & -9.9 & 9.3 \\
\hline Errors and omissions & -6.1 & -7.9 & 42.9 & -2.7 & -2.1 & 3.3 & -0.9 \\
\hline Overall balance & 16.3 & 77.5 & 90.0 & -2.5 & -28.7 & -28.2 & -16.1 \\
\hline Financing & -16.3 & -77.5 & -90.0 & 2.5 & 28.7 & 28.2 & 16.1 \\
\hline Net foreign assets & -43.8 & -65.1 & -94.3 & 1.0 & 25.2 & 24.7 & 11.2 \\
\hline Net official reserves & -39.6 & 9.3 & -51.2 & -1.6 & -3.6 & 16.3 & 23.8 \\
\hline Gross official reserves & -48.1 & -8.4 & -69.1 & -7.6 & -15.6 & 5.2 & 15.5 \\
\hline IMF (net) & 8.5 & 17.7 & 17.9 & 6.0 & 12.0 & 11.1 & 8.3 \\
\hline Net foreign assets, commercial banks $2 /$ & -4.3 & -74.4 & -43.1 & 2.6 & 28.8 & 8.4 & -12.7 \\
\hline Change in arrears (reduction $=-$ ) & 19.2 & -22.2 & -1.8 & 0.0 & 0.0 & 0.0 & 0.0 \\
\hline Debt relief $3 /$ & 8.3 & 9.8 & 6.1 & 1.5 & 0.0 & 0.0 & 0.0 \\
\hline \multicolumn{8}{|l|}{ Memorandum item: } \\
\hline CFA franc per SDR (period average) & 395.4 & 782.9 & 757.2 & 743.4 & 802.0 & 794.2 & 840.4 \\
\hline
\end{tabular}

Sources: Central Bank of West African States (BCEAO); and staff estimates.

1/ Includes portfolio investment and direst foreign investment.

2/ Including net foreign assets of Post Office.

3 / Including relief on government-guaranteed debt. 
Table 31. Burkina Faso: Composition of Exports, 1993-99

\begin{tabular}{|c|c|c|c|c|c|c|c|}
\hline & 1993 & 1994 & 1995 & 1996 & 1997 & 1998 & 1999 \\
\hline & \multicolumn{7}{|c|}{$\begin{array}{l}\text { (Unless otherwise indicated, all values in billions of CFA francs, } \\
\text { volumes in thousands of metric tons, and prices in CFA francs per kilogram) }\end{array}$} \\
\hline Total exports, fo.b. & 74.5 & 104.4 & 118.2 & 119.0 & 133.7 & 190.4 & 156.6 \\
\hline Cotton & 22.2 & 31.7 & 51.2 & 49.6 & 74.6 & 120.9 & 83.6 \\
\hline Volume & 62.0 & 48.4 & 62.0 & 64.0 & 89.4 & 138.8 & 114.7 \\
\hline Price & 358.0 & 656.0 & 825.0 & 775.0 & 835.0 & 870.6 & 728.7 \\
\hline Livestock products & 8.2 & 33.1 & 35.5 & 33.0 & 27.1 & 27.0 & 29.3 \\
\hline Live animals & 4.2 & 22.4 & 22.9 & 17.5 & 14.6 & 14.6 & 15.8 \\
\hline Heads $(1,000)$ & 152.6 & 417.4 & 390.2 & 350.0 & 300.0 & 300.0 & 310.0 \\
\hline Price $(1,000$ CFA francs/head $)$ & 27.2 & 53.4 & 58.8 & 50.0 & 48.5 & 48.7 & 51.1 \\
\hline Meats and slaughtered animals & 0.9 & 1.3 & 1.8 & 1.8 & 1.5 & 1.6 & 1.7 \\
\hline Volume & 0.8 & 0.8 & 1.2 & 1.2 & 1.0 & 1.0 & 1.1 \\
\hline Price & $1,150.0$ & $1,610.0$ & $1,500,0$ & $1,500.0$ & $1,500.0$ & $1,500.7$ & $1,607.5$ \\
\hline Leather and hides & 3.2 & 9.4 & 10.8 & 13.7 & 11.1 & 10.9 & 11.8 \\
\hline Volume & 2.1 & 3.0 & 3.6 & 4.2 & 3.4 & 3.3 & 3.4 \\
\hline Price & $1,500.0$ & $3,100.0$ & $2,972.0$ & $3,300.0$ & $3,300.0$ & $3,300.0$ & $3,430.0$ \\
\hline Gold & 8.1 & 12.2 & 11.7 & 9.0 & 9.0 & 9.5 & 9.2 \\
\hline Volume (metric tons) & 3.0 & 1.6 & 1.9 & 1.4 & 1.4 & 1.6 & 1.8 \\
\hline Price $(1,000$ CFA francs/kilogram) & $2,716.0$ & $5,926.0$ & $6,164.0$ & $6,500.0$ & $6,600.0$ & $5,937.5$ & $5,122.2$ \\
\hline Manganese & 0.7 & 0.7 & 0.6 & 0.7 & 0.0 & 0.0 & 0.0 \\
\hline Volume & 25.0 & 12.4 & 13.0 & 13.4 & 0.0 & 0.0 & 0.0 \\
\hline Price & 28.9 & 56.1 & 48.8 & 51.6 & 60.5 & 62.7 & 67.9 \\
\hline Zinc & 0.0 & 0.0 & 0.0 & 0.0 & 0.0 & 0.0 & 0.0 \\
\hline Volume (metric tons) & 0.0 & 0.0 & 0.0 & 0.0 & 0.0 & 1.0 & 1.1 \\
\hline Price (1000 CFA francs/metric ton) & $\cdots$ & $\cdots$ & $\cdots$ & $\ldots$ & $\ldots$ & 675.2 & 661.5 \\
\hline \multirow[t]{2}{*}{ Other } & 35.2 & 26.6 & 19.2 & 26.8 & 22.9 & 33.0 & 34.5 \\
\hline & \multicolumn{7}{|c|}{ (In percent of total exports) } \\
\hline Cotton & 29.8 & 30.4 & 43.3 & 41.7 & 55.8 & 63.5 & 53.4 \\
\hline Livestock products & 11.0 & 31.7 & 30.0 & 27.7 & 20.3 & 14.2 & 18.7 \\
\hline Live animals & 5.6 & 21.5 & 19.4 & 14.7 & 10.9 & .7 .7 & 10.1 \\
\hline Meats and slaughtered animals & 1.2 & 1.3 & 1.5 & 1.5 & 1.1 & 0.8 & 1.1 \\
\hline Leather and hides & 4.2 & 9.0 & 9.1 & 11.5 & 8.3 & 5.7 & 7.5 \\
\hline Goid & 10.9 & 11.7 & 9.9 & 7.6 & 6.7 & 5.0 & 5.9 \\
\hline Manganese & 1.0 & 0.7 & 0.5 & 0.6 & 0.0 & 0.0 & 0.0 \\
\hline Zinc & 0.0 & 0.0 & 0.0 & 0.0 & 0.0 & 0.0 & 0.0 \\
\hline Other & 47.3 & 25.5 & 16.2 & 22.5 & 17.1 & 17.3 & 22.0 \\
\hline \multirow[t]{2}{*}{ Total } & 100.0 & 100.0 & 100.0 & 100.0 & 100.0 & 100.0 & 100.0 \\
\hline & \multicolumn{7}{|c|}{ (Changes in percent of export values) } \\
\hline Total exports, fo.b. & 18.3 & 40.1 & 13.2 & 0.7 & 12.3 & 42.5 & -17.8 \\
\hline Cotton & .11 .3 & 43.0 & 61.1 & -3.0 & -3.4 & 61.9 & -30.8 \\
\hline Livestock products & -5.7 & 303.6 & 7.3 & -7.1 & .20 .7 & -0.2 & 8.5 \\
\hline Gold & -4.3 & 49,9 & -4.3 & -23.0 & -11.2 & 5.5 & -2.9 \\
\hline
\end{tabular}

Source: Central Bank of West African States (BCEAO). 
Table 32. Burkina Faso: Composition of Imports, 1993-99

\begin{tabular}{|c|c|c|c|c|c|c|c|}
\hline & 1993 & 1994 & 1995 & 1996 & 1997 & 1998 & $\begin{array}{r}1999 \\
\text { Est. }\end{array}$ \\
\hline & \multicolumn{7}{|c|}{ (In billions of CFA francs) } \\
\hline Total imports, f.o.b. & 153.0 & 193.9 & 242.2 & 288.0 & 297.7 & 374.2 & 368.7 \\
\hline Food products & 26.0 & 34.0 & 35.0 & 43.9 & 41.3 & 83.7 & 45.5 \\
\hline Petroleum products & 28.2 & 24.7 & 25.9 & 37.6 & 40.1 & 42.0 & 62.4 \\
\hline Capital equipment & 32.2 & 44.2 & 75.4 & 86.8 & 90.4 & 114.5 & 135.8 \\
\hline Raw materials & 6.7 & 12.0 & 21.0 & 21.5 & 23.4 & 40.0 & 35.0 \\
\hline \multirow[t]{2}{*}{ Miscellaneous and unclassified $1 /$} & 60.0 & 79.0 & 85.0 & 98.2 & 102.5 & 94.0 & 89.9 \\
\hline & \multicolumn{7}{|c|}{ (In percent of total) } \\
\hline Total imports, f.o.b. & 100.0 & 100.0 & 100.0 & 100.0 & 100.0 & 100.0 & 100.0 \\
\hline Food products & 17.0 & 17.5 & 14.4 & 15.2 & 13.9 & 22.4 & 12.3 \\
\hline Petroleum products & 18.4 & 12.8 & 10.7 & 13.1 & 13.5 & 11.2 & 16.9 \\
\hline Capital equipment & 21.0 & 22.8 & 31.1 & 30.1 & 30.4 & 30.6 & 36.8 \\
\hline Raw materials & 4.4 & 6.2 & 8.7 & 7.5 & 7.9 & 10.7 & 9.5 \\
\hline \multirow[t]{2}{*}{ Miscellaneous and unclassified 1/ } & 39.2 & 40.7 & 35.1 & 34.1 & 34.4 & 25.1 & 24.4 \\
\hline & \multicolumn{7}{|c|}{ (Changes in percent) } \\
\hline Total imports, f.o.b. & 12.0 & 26.7 & 24.9 & 18.9 & 3.4 & 25.7 & -1.5 \\
\hline Food products & 9.7 & 30.8 & 2.9 & 25.4 & -5.9 & 102.6 & -45.6 \\
\hline Petroleum products & 99.9 & -12.2 & 4.6 & 45.4 & 6.6 & 4.8 & 48.6 \\
\hline Capital equipment & -7.2 & 37.3 & 70.6 & 15.1 & 4.2 & 26.7 & 18.6 \\
\hline Raw materials & -8.1 & 80.0 & 75.0 & 2.4 & 8.9 & 70.8 & -12.5 \\
\hline Miscellaneous and unclassified 1/ & 5.4 & 31.7 & 7.6 & 15.5 & 4.4 & -8.3 & -4.3 \\
\hline
\end{tabular}

Sources: Central Bank of West African States (BCEAO); and staff estimates.

1/ Including adjustments for unrecorded imports. 
Table 33. Burkina Faso: Services and Transfers, 1993-99

(In billions of CFA franes)

\begin{tabular}{|c|c|c|c|c|c|c|c|}
\hline & 1993 & 1994 & 1995 & 1996 & 1997 & 1998 & 1999 \\
\hline Services and income (net) & -42.8 & -53.3 & -61.6 & -64.7 & -72.9 & -80.5 & -83.3 \\
\hline Income (net) & -3.8 & -7.8 & -5.7 & -4.0 & -7.8 & -7.0 & -7.8 \\
\hline Services (net) & -39.0 & -45.6 & -56.0 & -60.7 & -65.1 & -73.5 & -75.4 \\
\hline Services (net) & -39.0 & -45.6 & -56.0 & -60.7 & -65.1 & -73.5 & -75.4 \\
\hline Credit & 17.7 & 31.2 & 34.4 & 22.3 & 22.1 & 22.8 & 23.0 \\
\hline Debit & -56.8 & -76.8 & -90.4 & -83.0 & -87.3 & -96.3 & -98.4 \\
\hline Freight and insurance & -27.5 & -30.6 & -41.2 & -46.0 & -51.1 & -69.9 & -66.3 \\
\hline Credit & 0.0 & 0.0 & 0.0 & 0.0 & 0.0 & 0.0 & 0.0 \\
\hline Debit & -27.5 & -30.6 & -41.2 & -46.0 & -51.1 & -69.9 & -66.3 \\
\hline Other transport & -5.8 & -4.8 & -4.9 & -5.9 & -5.6 & -4.5 & -4.3 \\
\hline Credit & 2.2 & 3.7 & 3.7 & 2.4 & 2.6 & 2.6 & 3.0 \\
\hline Debit & -8.0 & -8.5 & -8.5 & -8.3 & -8.1 & -7.1 & -7.3 \\
\hline Travel & 0.6 & -2.4 & -1.5 & -3.4 & -2.9 & -1.0 & -6.6 \\
\hline Credit & 6.5 & 10.2 & 12.0 & 12.1 & 13.4 & 12.8 & 12.7 \\
\hline Debit & -6.0 & -12.6 & -13.6 & -15.6 & -16.3 & -13.8 & -19.4 \\
\hline Government services & -2.0 & -2.6 & -2.0 & 1.0 & -0.9 & -1.5 & -1.6 \\
\hline Credit & 6.1 & 9.9 & 10.7 & 3.4 & 2.0 & 1.8 & 1.7 \\
\hline Debit & -8.1 & -12.5 & -12.6 & -2.5 & -3.0 & -3.2 & -3.3 \\
\hline Other nonfactor services & -4.3 & -5.1 & -6.4 & -6.3 & -4.6 & 3.4 & 3.3 \\
\hline Credit & 2.9 & 7.4 & 8.0 & 4.4 & 4.1 & 5.6 & 5.5 \\
\hline Debit & -7.2 & -12.6 & -14.5 & -10.7 & -8.7 & -2.2 & -2.2 \\
\hline Income (net) & -3.8 & -7.8 & -5.7 & -4.0 & -7.8 & -7.0 & -7.8 \\
\hline Credit & 5.1 & 5.4 & 5.6 & 14.2 & 10.0 & 8.5 & 8.9 \\
\hline Debit & -9.0 & -13.2 & -11.2 & -18.2 & -17.8 & -15.6 & -16.7 \\
\hline Transfers (net) & 102.8 & 159.4 & 170.5 & 192.4 & 187.2 & 195.6 & 212.4 \\
\hline Private & 43.9 & 53.6 & 53.0 & 43.0 & 43.4 & 43.9 & 41.0 \\
\hline Credit & 47.4 & 67.5 & 68.0 & 70.6 & 72.5 & 72.9 & 70.0 \\
\hline Of which: workers' remittances & 33.2 & 54.6 & 55.1 & 56.4 & 51.1 & 54.4 & 51.0 \\
\hline Debit & -3.5 & -13.9 & -15.0 & -27.6 & -29.1 & -29.0 & -29.0 \\
\hline Official & 58.9 & 105.8 & 117.5 & 147.2 & 140.0 & 151.7 & 171.4 \\
\hline Credit & 61.4 & 108.8 & 120.6 & 149.5 & 141.1 & 154.3 & 174.1 \\
\hline Of which : capital grants & 28.0 & 35.4 & 51.2 & 81.8 & 81.1 & 84.1 & 117.4 \\
\hline Debit & -2.5 & -3.0 & -3.1 & -2.3 & -1.0 & -2.6 & -2.7 \\
\hline
\end{tabular}

Sources: Central Bank of West African States (BCEAO); and staff estimates. 
Table 34. Burkina Faso: Direction of Recorded Exports, 1993-98

\begin{tabular}{|c|c|c|c|c|c|c|}
\hline & 1993 & 1994 & 1995 & 2996 & 1997 & 1998 \\
\hline & \multicolumn{6}{|c|}{ (In billions of CFA francs) } \\
\hline Europe & 7.4 & 26.4 & 35.9 & 40.1 & 58.1 & 100.7 \\
\hline $\begin{array}{l}\text { European Conmmunity } \\
\text { Of which }\end{array}$ & 6.3 & 17.4 & 23.2 & 23.1 & 34.0 & si.9 \\
\hline \multicolumn{7}{|l|}{ Of which } \\
\hline Betgitur/Luxembourg & 4.2 & 6.8 & 12.3 & 13.5 & 16.7 & 32.3 \\
\hline Germany & .0 .0 & $\ldots 3$ & $\ldots$ & 3.5 & 10.8 & 15.2 \\
\hline Jtaly & 1.1 & 6.8 & $\begin{array}{l}0.1 \\
6.8\end{array}$ & 0.3 & 0.1 & 0.4 \\
\hline Denmark & 0.0 & 0.0 & $\begin{array}{l}6.8 \\
0.1\end{array}$ & 2.9 & 3.0 & 0.3 \\
\hline United Kingdom & 0.5 & 0.3 & $\begin{array}{l}0.1 \\
0.2\end{array}$ & 0.2 & 0.2 & 0.3 \\
\hline Other & 1.1 & 9.0 & $\begin{array}{r}0.2 \\
12.6\end{array}$ & 1,3 & 0.9 & 0,2 \\
\hline & & & & {$[7.1$} & 24.1 & 48.8 \\
\hline Africa & 9.9 & 19.6 & 26.6 & 25.1 & 21.8 & 27.0 \\
\hline $\begin{array}{l}\text { West Affican Monetsy Union } \\
\text { Of which }\end{array}$ & 8.7 & 14.7 & 20.4 & 18.7 & 16.4 & 22.5 \\
\hline Côte d'Jvoire & 6.9 & 10.8 & 16.4 & 11.2 & $\mathrm{t} 1.7$ & 13.7 \\
\hline Niger & 0.2 & 0.8 & 0.7 & 1.1 & 1.5 & 1.4 \\
\hline Togo & 0.3 & 0.0 & 2.6 & 3.5 & 3.6 & 2.1 \\
\hline Mali & 1.1 & 0.5 & 0.4 & 1.1 & 1.3 & 2.4 \\
\hline Benyin & $\ldots$ & $\ldots$ & $\cdots$ & $\cdots$ & $0 A$ & 2.6 \\
\hline Ghana & 0.5 & 2.3 & 2.2 & 2.7 & 3.7 & 3.0 \\
\hline Nigeria & 0.1 & 0.0 & 0.1 & 0.1 & 0.0 & 1.1 \\
\hline Other & 0.5 & 0.0 & 62 & 3.6 & 1.7 & 0.4 \\
\hline $\begin{array}{l}\text { Western Hemispbert } \\
\text { Of which }\end{array}$ & 0.2 & 0.6 & 1.1 & 0.6 & & 4.0 \\
\hline United States & 0.1 & 0.0 & 0.2 & 0.3 & 1.8 & 0.2 \\
\hline Comiada & 0.0 & 0.0 & 0.0 & 0.2 & 0.0 & 0.0 \\
\hline Colombia & 0.0 & 0.0 & 0.0 & 0.0 & 1.3 & 3.7 \\
\hline \multicolumn{7}{|l|}{ Of which } \\
\hline China, People's Republic of & 0.0 & 0.0 & 0.0 & 0.2 & 0.0 & 0.0 \\
\hline Tajwan Province of China & 0.7 & 5.8 & 1.4 & 0.8 & 4.1 & 0.0 \\
\hline Japen & 0.7 & 1.8 & 2.6 & 0.1 & 1.1 & 0.4 \\
\hline Hong Kong, SAR & 0.0 & 0.7 & 2.0 & 0.9 & 0.7 & 0.0 \\
\hline Indonesia & $\cdots$ & $\cdots$ & $\ldots$ & 23.2 & 7.1 & 0.0 \\
\hline Singapore & $\cdots$ & $\cdots$ & .. & 0.5 & 5.4 & 7.8 \\
\hline Other countries & 0.0 & 0.0 & 0.0 & 1.7 & 1.2 & 0.2 \\
\hline \multirow[t]{2}{*}{ Total } & 19.7 & 59.2 & 80.1 & 96.5 & 106.9 & $\$ 40.0$ \\
\hline & \multicolumn{6}{|c|}{ (In percent of total) } \\
\hline Europe & 37.5 & 44.6 & 44.8 & 41.6 & 54.4 & 71.9 \\
\hline European Community & 31.9 & 29.4 & 29.0 & 23.9 & 31.8 & 37.1 \\
\hline \multicolumn{7}{|l|}{ Of which } \\
\hline France & 21.1 & 11.5 & 15.3 & 14.0 & 35.6 & 23.1 \\
\hline BelgiuntLLuxempbourg & $\ldots$ & $\ldots$ & $\ldots$ & 3.6 & 10.1 & 10.8 \\
\hline Germany & 0.1 & 0.5 & 0.1 & 0.3 & 0.1 & 0.3 \\
\hline Italy & 5.7 & 11.5 & 8.5 & 3.0 & 2.8 & 0.2 \\
\hline Denmark & 0.0 & 0.0 & 0.2 & 0.2 & 0.2 & 0.2 \\
\hline United Kingogont & 0.3 & 0.5 & 0.3 & 1.4 & 0.8 & 0.1 \\
\hline Other & 5.6 & 15.1 & 15.8 & 17.7 & 22.6 & 34.9 \\
\hline Africa & 50.1 & 33.2 & 33.2 & 26.0 & 20.4 & 19.2 \\
\hline $\begin{array}{l}\text { West Aftican Monetary Union } \\
\text { Of which }\end{array}$ & 44.2 & 24.8 & 25.5 & 19.4 & 15.3 & 16.0 \\
\hline Côte d'lvoire & 34.9 & 18.2 & 20.5 & 11.6 & 10.9 & 9.8 \\
\hline Niger & 1.3 & 1.4 & 0.9 & 1.1 & 1.4 & 1.0 \\
\hline Togo & 1.7 & 0.0 & 3.2 & 3.6 & 3.3 & 1.5 \\
\hline Mali & 5.4 & 0.9 & 0.5 & 1.1 & 1.2 & 1.7 \\
\hline Benin & $\ldots$ & $\ldots$ & $\ldots$ & $\ldots$ & 0.3 & 1.9 \\
\hline Ghana & 2.7 & 3.9 & 2.7 & 2.8 & 3.5 & 2.1 \\
\hline Nigerís & 0.6 & 0.0 & 0.1 & 0.1 & 0.0 & 0.7 \\
\hline Otber & 2.6 & 0.0 & 7.8 & 3.7 & 1.6 & 0.3 \\
\hline $\begin{array}{l}\text { Western Hemispbere } \\
\text { Of which }\end{array}$ & 0.9 & 1.1 & 1.4 & 0.6 & 3.2 & 2.8 \\
\hline United States & 0.3 & 0.1 & 0.3 & 0.3 & 1.7 & 0.2 \\
\hline Canzada & 0.1 & 0.0 & 0.0 & 0.2 & 0.0 & 0.0 \\
\hline Colombia & $\ldots$ & $\ldots$ & $\cdots$ & 0.0 & 1.2 & 2.6 \\
\hline & \multicolumn{6}{|c|}{ Of which } \\
\hline China, People's Republic of & 0.1 & 0.0 & 0.0 & 0.2 & 0.0 & 0.0 \\
\hline Taiwan Province of China & 3.5 & 9.7 & 1.7 & 0.8 & 3.8 & 0.0 \\
\hline Japan & 3.5 & 3.0 & 3.2 & 0.1 & t.1 & 0.3 \\
\hline Hong Kong, SAR & 0.0 & 1.1 & 2.5 & 0.9 & 0.6 & 0.0 \\
\hline Indonessia & $\ldots$ & $\cdots$ & $\ldots$ & 24.0 & 6.6 & 0.0 \\
\hline Singaport & $\cdots$ & $m$ & $\ldots$ & 0.5 & 5.1 & 5.6 \\
\hline Other countries & 0.0 & 0.0 & 0.0 & 1.8 & l.1 & 0.1 \\
\hline Total & 100.0 & 100.0 & 100.0 & 100.0 & 100.0 & 100.0 \\
\hline
\end{tabular}


Table 35. Burkina Faso: Origin of Recorded Imports, c.i.f., $1993-98$

\begin{tabular}{|c|c|c|c|c|c|c|}
\hline & 1993 & 1994 & 1995 & 1996 & 1997 & 1998 \\
\hline & \multicolumn{6}{|c|}{ (In billions of CFA francs) } \\
\hline Europe & 62.7 & 91.6 & 105.4 & 147.9 & 156.7 & 194.7 \\
\hline European Community & 61.4 & 89.6 & 94.1 & 144.2 & 141.1 & 182.1 \\
\hline Of which: France & 35.2 & 50.9 & 58.2 & 81.9 & 88.5 & 115.2 \\
\hline Germany & 5.2 & 7.3 & 7.7 & 13.3 & 8.4 & 11.1 \\
\hline Netherlands & 6.2 & 5.6 & 8.2 & 5.8 & 10.1 & 11.4 \\
\hline Belgitan/Luxembourg & 3.6 & 5.2 & 9.9 & 9.0 & 7.6 & 8.9 \\
\hline \multirow{2}{*}{$\begin{array}{l}\text { United Kingdom } \\
\text { Italy }\end{array}$} & 2.0 & 1.9 & 3.9 & 5.9 & 4.1 & 5.3 \\
\hline & 3.5 & 5.5 & 6.3 & 13.2 & 12.2 & 12.8 \\
\hline Other & 1.3 & 2.0 & 11.3 & 3.7 & 15.6 & 12.6 \\
\hline Africa & 43.4 & 57.7 & 68.8 & 88.6 & 86.2 & 99.0 \\
\hline \multirow{2}{*}{$\begin{array}{l}\text { West African Monetary Union } \\
\text { Of which: Côte d'Ivoire }\end{array}$} & 30.4 & 46.3 & 40.9 & 65.5 & 68.8 & 85.0 \\
\hline & 25.7 & 33.2 & 34.9 & 51.3 & 58.1 & 67.0 \\
\hline Senegal & 1.9 & 3.3 & 2.8 & 2.1 & 4.8 & 4.2 \\
\hline Togo & 1.1 & 3.1 & 2.5 & 3.0 & 4.4 & 5.3 \\
\hline \multirow[b]{2}{*}{ Ghana } & 0.8 & 0.6 & 0.7 & 0.7 & 0.9 & 1.6 \\
\hline & 1.6 & 2.1 & 2.7 & 2.7 & 3.0 & 3.5 \\
\hline Nigería & 9.5 & 7.3 & 13.3 & 13.8 & 8.4 & 3.7 \\
\hline Other & 2.0 & 1.9 & 12.2 & 6.7 & 6.0 & 6.8 \\
\hline Western Hemisphere & $\ldots$ & $\cdots$ & $\ldots$ & 17.2 & 19.4 & 25.8 \\
\hline Of which: United States & 8.4 & 16.1 & 18.0 & 12.6 & 13.4 & 14.1 \\
\hline Canada & 1.0 & 0.8 & $\ldots$ & $\ldots$ & $\cdots$ & $\ldots$ \\
\hline Asia & 22.3 & 27.9 & 34.6 & 46.6 & 45.2 & 64.3 \\
\hline Of which: Japan & 9.2 & 10.7 & 15.7 & 17.3 & 17.0 & 20.7 \\
\hline China, People's Republic of & 8.1 & 5.8 & 4.0 & 3.5 & 3.5 & 5.9 \\
\hline Taiwan Province of China & 0.9 & 2.0 & 1.7 & 2.5 & 2.2 & 0.9 \\
\hline Pakistan & 0.0 & 2.1 & 0.7 & 2.9 & 6.8 & S.o \\
\hline India & $\ldots$ & $\ldots$ & $\ldots$ & 12.0 & 3.2 & 9.8 \\
\hline Vietnam & $\ldots$ & $\ldots$ & $\cdots$ & 5.5 & 5.6 & 6.4 \\
\hline Other countries & 7.2 & 0.4 & 4.4 & 1.5 & 1.8 & 2.2 \\
\hline Total & 144,0 & 193.7 & 227.2 & 301.8 & 309.3 & 385.9 \\
\hline & & & percent & f total) & & \\
\hline Europe & 43.5 & 47.3 & 46.4 & 49.0 & 50.7 & 50.4 \\
\hline European Community & 42.7 & 46.3 & 41.4 & 47.8 & 45.6 & 47.2 \\
\hline Of which: France & 24.5 & 26.3 & 25.6 & 27.1 & 28.6 & 29.8 \\
\hline Germany & 3.6 & 3.8 & 3.4 & 4.4 & 2.7 & 2.9 \\
\hline Netherlands & 4.3 & 2.9 & 3.6 & 1.9 & 3.3 & 3.0 \\
\hline Belgium/Luxembourg & 2.5 & 2.7 & 4.4 & 3.0 & 2.5 & 2.3 \\
\hline United Kingdom & 1.4 & 1.0 & 1.7 & 1.9 & 1.3 & 1.4 \\
\hline Italy & 2.4 & 2,9 & 2.8 & 4.4 & 3.9 & 3.3 \\
\hline Other & 0.9 & 1.0 & 5.0 & 1.2 & 5.1 & 3.3 \\
\hline Africa & 30.1 & 29.8 & 30.3 & 29.4 & 27.8 & 25.6 \\
\hline West African Monetary Union & 21.1 & 23.9 & 18.0 & 21.7 & 22.2 & 22.0 \\
\hline Of which: Cöte d'Ivoire & 17.9 & 17.1 & 15.4 & 17.0 & 18.8 & 17.4 \\
\hline Senegal & 1.3 & 1.7 & 1.2 & 0.7 & 1.5 & 1.1 \\
\hline Togo & 0.8 & 1.6 & i.1 & 1.0 & 1.4 & 1.4 \\
\hline Mali & 0.5 & 0.3 & 0.3 & 0.2 & 0.3 & 0.4 \\
\hline Ghana & 1.1 & 1.1 & 1.2 & 0.9 & 1.0 & 0.9 \\
\hline Nigeria & 6.6 & 3.8 & 5.9 & 4.6 & 2.7 & 1.0 \\
\hline Other & 1.4 & 1.0 & 5.4 & 2.2 & 1.9 & 1.8 \\
\hline Western Hemisphere & $\ldots$ & $\cdots$ & $\ldots$ & 5.7 & 6.3 & 6.7 \\
\hline Of which: United States & 5.9 & 8.3 & 7.9 & 4.2 & 4.3 & 3.6 \\
\hline Canada & 0.7 & 0.4 & 0.0 & 0.0 & 0.0 & 0.0 \\
\hline Asja & 15.5 & 14.4 & 15.2 & 15.4 & 14.6 & 16.7 \\
\hline Of which: Japan & 6.4 & 5.5 & 6.9 & 5.7 & 5.5 & 5.4 \\
\hline China, People's Republic of & 5.6 & 3.0 & 1.7 & i.l & 1.1 & 1.5 \\
\hline Taiwan, Province of & 0.6 & 1,0 & 0.7 & 0.8 & 0.4 & 0.2 \\
\hline Pakistan & 0.0 & 1.1 & 0.3 & 0.9 & 2.2 & 13 \\
\hline India & $\cdots$ & $\cdots$ & $\ldots$ & 4.0 & 1.0 & 2.5 \\
\hline Vietraan & $\cdots$ & $\cdots$ & $\cdots$ & 1.8 & 1.8 & 1.6 \\
\hline Other countries & 5.0 & 0.2 & 1.9 & 0.5 & 0.6 & 0.6 \\
\hline Total & 100.0 & 100.0 & 100.0 & 100.0 & 100.0 & 100.0 \\
\hline
\end{tabular}

Source: Central Bank of West African States (BCEAO). 
Table 36. Burkina Faso: Nominal and Net Present Value (NPV) of External Debt Outstanding, as of End-Decenber 1999 1/

\begin{tabular}{|c|c|c|c|c|c|c|}
\hline & \multicolumn{3}{|c|}{ Nominal Debt } & \multicolumn{3}{|c|}{ NPV of Debt } \\
\hline & $\begin{array}{r}\text { In millions } \\
\text { of U.S. dollars }\end{array}$ & $\begin{array}{l}\text { In percent } \\
\text { of total }\end{array}$ & $\begin{array}{l}\text { In percent } \\
\text { of group }\end{array}$ & $\begin{array}{l}\text { In millions } \\
\text { of U.S. dollars }\end{array}$ & $\begin{array}{l}\text { In percent } \\
\text { of total }\end{array}$ & $\begin{array}{l}\text { In percent } \\
\text { of group }\end{array}$ \\
\hline Total & $1,544.1$ & 100.0 & 100.0 & 926.6 & 100.0 & 100.0 \\
\hline Multilateral institutions & $1,321.6$ & 85.6 & 100.0 & 738.5 & 79.7 & 100.0 \\
\hline African Development Bank and Fund & 249.4 & 16.1 & 18.9 & 140.6 & 9.1 & 10.6 \\
\hline Arab Bank for Economic Development in Africa (BADEA) & 35.4 & 2.3 & 2.7 & 29.3 & 3.2 & 4.0 \\
\hline Development Bank of West Africa (BOAD) & 14.8 & 1.0 & 1.1 & 14.3 & 1.5 & 1.9 \\
\hline Economic Community of West African States (ECOWAS) & 5.8 & 0.4 & 0.4 & 6.2 & 0.7 & 0.8 \\
\hline European Investment Bank & 46.9 & 3.0 & 3.6 & 35.3 & 3.8 & 4.8 \\
\hline \multicolumn{7}{|l|}{ Fonds d'Éntraide et de Garantie des Empreants du Conseil } \\
\hline de l'Éntente (FEGECE) & 0.1 & 0.0 & 0.0 & 0.1 & 0.0 & 0.0 \\
\hline IDA & 752.9 & 48.8 & 57.0 & 355.5 & 38.4 & 48.1 \\
\hline International Fund for Agricultural Development (IFAD) & 28.9 & 1.9 & 2.2 & 14.0 & 1.5 & 1.9 \\
\hline MF & 120.7 & 7.8 & 9.1 & 96.0 & 10.4 & 13.0 \\
\hline Islamic Development Bank & 44.9 & 2.9 & 3.4 & 29.0 & 3.1 & 3.9 \\
\hline OPEC Fund & 21.7 & 1.4 & 1.6 & 18.2 & 2.0 & 2.5 \\
\hline Paris Club creditors & 58.9 & 3.8 & 100.0 & 49.2 & 5.3 & 100.0 \\
\hline Post-cutoff date & 17.4 & 1.1 & 29.6 & 16.9 & 1.8 & 34.3 \\
\hline Pre-cutoff date & 41.5 & 2.7 & 70.4 & 32.4 & 3.5 & 65.7 \\
\hline Of which: ODA & 4.4 & 0.3 & 7.4 & 3.9 & 0.4 & 8.0 \\
\hline \multicolumn{7}{|l|}{ By country: } \\
\hline Austria & 5.8 & 0.4 & 9.9 & 2.5 & 0.3 & 5.1 \\
\hline France & 25.1 & 1.6 & 42.6 & 27.1 & 2.9 & 55.1 \\
\hline Italy & 11.3 & 0.7 & 19.1 & 5.7 & 0.6 & 11.6 \\
\hline Netherlands & 4.5 & 0.3 & 7.6 & 5.2 & 0.6 & 10.6 \\
\hline Russia & 2.1 & 0.1 & 3.6 & 0.8 & 0.1 & 1.7 \\
\hline Spain & 8.6 & 0.6 & 14.5 & 6.1 & 0.7 & 12.3 \\
\hline United Kingdom & 1.6 & 0.1 & 2.7 & 1.8 & 0.2 & 3.7 \\
\hline Non-Paris Club creditors & 163.6 & 10.6 & 100.0 & 138.8 & 15.0 & 100.0 \\
\hline Post-cutoff date & 44.8 & 2.9 & 27.4 & 34.3 & 3.7 & 24.7 \\
\hline Pre-cutoff date & 118.8 & 7.7 & 72.6 & 104.5 & 11.3 & 75.3 \\
\hline Of which: ODA & 51.9 & 3.4 & 31.7 & 43.8 & 4.7 & 31.5 \\
\hline \multicolumn{7}{|l|}{ By country: } \\
\hline Algeria & 4.5 & 0.3 & 2.8 & 4.4 & 0.5 & 3.2 \\
\hline China & 22.3 & 1.4 & 13.7 & 20.5 & 2.2 & 14.7 \\
\hline Côte d'Troire & 45.2 & 2.9 & 27.6 & 39.7 & 4.3 & 28.6 \\
\hline Kuwait & 39.5 & 2.6 & 24.1 & 29.3 & 3.2 & 21.1 \\
\hline Saudi Arabia & 21.3 & 1.4 & 13.0 & 17.2 & 1.9 & 12.4 \\
\hline Lybia & 18.5 & 1.2 & 11.3 & 17.9 & 1.9 & 12.9 \\
\hline Taiwan Province of China & 12.3 & 0.8 & 7.5 & 9.9 & 1.1 & 7.1 \\
\hline \multicolumn{7}{|l|}{ Memorandum items: } \\
\hline Three-year average of export of goods and nonfactor & $\cdots$ & & & & & \\
\hline services (in millions of US dollars) & & $\ldots$ & $\cdots$ & 307.9 & ... & $\cdots$ \\
\hline Ratio of NPV to three-year average exports (in percent) & $\ldots$ & $\cdots$ & $\ldots$ & 300.9 & $\ldots$ & $\ldots$ \\
\hline
\end{tabular}

1/ After reduction of the stock of bilateral debt by the Paris Club in mid-1996.

Sources: Burkinabe authorities; and staff estimates. 